\title{
Change, Dependency, and Regime Plasticity in Offshore Financial Intermediation: The Saga of the Netherlands Antilles
}

Craig M. Boise

Andrew P. Morriss

Texas A\&M University School of Law, amorriss@law.tamu.edu

Follow this and additional works at: https://scholarship.law.tamu.edu/facscholar

Part of the Law Commons

\section{Recommended Citation}

Craig M. Boise \& Andrew P. Morriss, Change, Dependency, and Regime Plasticity in Offshore Financial Intermediation: The Saga of the Netherlands Antilles, 45 Tex. Int'I L. J. 377 (2009).

Available at: https://scholarship.law.tamu.edu/facscholar/265

This Article is brought to you for free and open access by Texas A\&M Law Scholarship. It has been accepted for inclusion in Faculty Scholarship by an authorized administrator of Texas A\&M Law Scholarship. For more information, please contact aretteen@law.tamu.edu. 


\title{
Change, Dependency, and Regime Plasticity in Offshore Financial Intermediation: The Saga of the Netherlands Antilles
}

\author{
CRAIG M. BOISE* \& ANDREW P. MORRISS**
}

\begin{abstract}
The legal regimes of offshore jurisdictions have historically differed in significant ways from those applicable in onshore jurisdictions. Inevitably, legal and financial professionals have seized upon these differences to develop strategies for reducing transactions costs. A prominent example of such cross-border arbitrage was the routing of Eurodollar loans through a small group of former Dutch island colonies in the Caribbean, a practice which peaked in the mid-1980s, when virtually every major U.S. corporation made interest payments to a Netherlands Antilles finance subsidiary. The "Antilles sandwich" strategy exploited the difference between high U.S. withholding tax rates that applied to interest payments made to most foreign lenders, and the zero rate of tax that applied to U.S. interest payments made to residents of the Antilles under the United States-Netherlands Antilles double taxation treaty. Both jurisdictions reaped significant benefits from the strategy until the United States unilaterally terminated the tax treaty in 1987, virtually wiping out the Antilles offshore financial sector overnight. Unfortunately, because of rigidity in its governance structure, the Antilles failed to develop alternative financial intermediation strategies to replace the Antilles sandwich structure before its demise.
\end{abstract}

The rise and fall of the Antilles' offshore financial sector provides insight into the current debate over the role of offshore financial centers like the Antilles within the global economy. Concerned about tax evasion by their residents, onshore jurisdictions

* Professor of Law, Director of Tax Programs, and Director, Institute for Offshore Financial Studies, DePaul University College of Law. B.A., University of Missouri-Kansas City; J.D., University of Chicago Law School; LL.M (Taxation), New York University School of Law. We thank the Mercatus Center at George Mason University for financial support for travel to Curaçao, Claire Morgan at Mercatus for her support, and the numerous people in Curaçao who took time from their schedules to talk to a couple of American law professors. In particular, Phyllis van den Hout of CIFA generously opened doors for us with many people. Eric Andersen, Hermann Behr, Felipe Croes, Gregory Elias, Errol Gova, Zuleika S. Lasten, Edgar Nunes, Shulaika Paassen-Delsol, Eric Passen, and Guiveron T. Weert graciously spent time with us, as well as others who asked not to be named. Matthew Brown, Justin Cook and Cyrus Sachinvala provided able research assistance. Thanks for helpful comments are owed as well to the participants in the faculty workshop in 2008 at George Mason University School of Law, particularly Eric Claeys, and to Allison Christians. As always, Andrew Dorchak and Stephanie Davidson cheerfully provided invaluable reference assistance that made our lives easier and improved the content immensely. Of course, all errors remain our own.

** H. Ross \& Helen Workman Professor of Law \& Professor of Business Administration, University of Illinois; Senior Scholar at the Mercatus Center at George Mason University, and Senior Fellow, Property \& Environment Research Center, Bozeman, Montana. A.B. Princeton University; J.D., M.Pub.Aff., University of Texas; Ph.D. (Economics) Massachusetts Institute of Technology. 
including France, Germany, and the United States are pressing for major changes in offshore jurisdictions' legal and regulatory regimes that may eliminate legitimate opportunities for international arbitrage. In such an environment, offshore financial centers may find it difficult to survive. In this article, we distill from the Antilles experience a theory of "regime plasticity" and examine the role that it plays in allowing offshore financial centers to adapt to changes in the legal and political environments within which they operate. How offshore financial centers react and whether they have learned the lessons of the Antilles' experience will play a major role in determining the future of the global offshore financial sector.

\section{SUMMARY}

I. INTRODUCTION .379

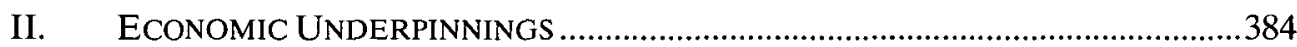

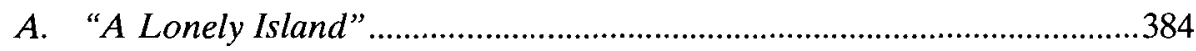

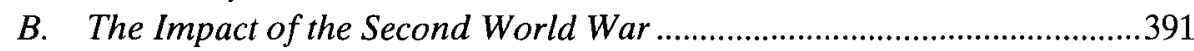

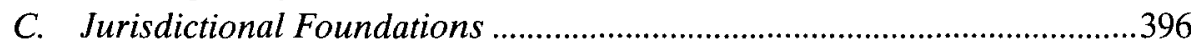

II. THE ARC OF ANTILLEAN FINANCIAL INTERMEDIATION ...............................401

A. The Economic Need to Create an Offshore Sector ...................................401

B. The Beginnings of Offshore Activity .......................................................404

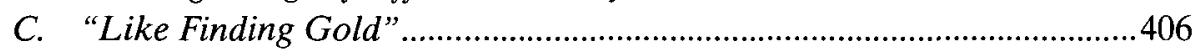

D. Expanding the Franchise ....................................................................4 410

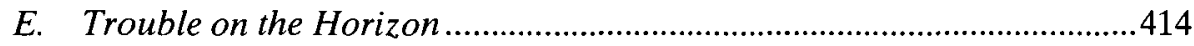

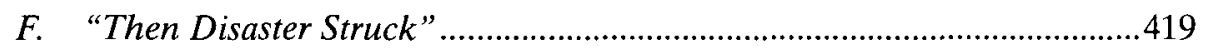

III. REgIME FLEXIBILITY, THE ANTILLES, AND THE FUTURE OF OFFSHORE FINANCIAL INTERMEDIATION ...............................................................4.426

A. A Theory of Regime Plasticity............................................................427

1. The Persistence of Difference ...........................................................427

2. The Challenge of Change .............................................................4 430

3. The Imperative of Legislative Agility ..........................................431

4. Constitutional Concerns ...................................................................444

B. The Netherlands Antilles in the Aftermath of Treaty Repeal...................435

1. The Post-Treaty Antilles and Legislative Flexibility .......................436

2. The Post-Treaty Antilles and Constitutional Concerns ..................437

IV. LESSONS FOR THE FUTURE OF OFFSHORE FINANCIAL INTERMEDIATION...441

A. The Prospects for the Antilles................................................................441

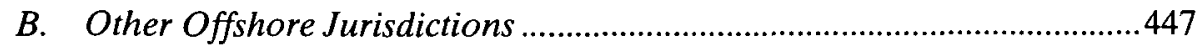

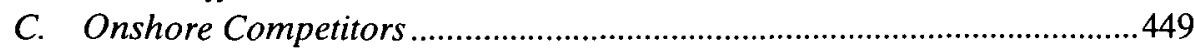

D. The Impact of Multilateral Institutions .................................................453

E. The Changing Climate .....................................................................454 


\section{INTRODUCTION}

In the immediate aftermath of World War II, world markets were littered with protective measures, exchange control regimes, tariffs, and endless quantitative trade restrictions. ${ }^{1}$ As the decades following the war passed, barriers to trade in goods gradually fell and, as trade grew, global capital markets also began to open. ${ }^{2}$ The pace of that opening varied considerably across jurisdictions around the globe, however, leading to significant differences among the legal regimes within those jurisdictions. It was virtually inevitable that legal and financial professionals would seize upon these differences to develop strategies for reducing transaction costs (including taxes and regulatory expenditures) through international arbitrage. One of the most prominent examples of this was the use of Netherlands Antilles international finance subsidiaries by U.S. companies to tap into the Eurodollar markets. $^{3}$ This practice peaked in the mid-1980s, when virtually every major U.S. corporation had at least one Antilles finance subsidiary. ${ }^{4}$

The "Antilles sandwich" financing strategy was not a result of competitive or opportunistic lawmaking by an offshore financial center. Rather, it exploited the then-existing difference between high withholding tax rates that applied to interest

1. Keetie E. Sluyterman, Dutch Enterprise in THE TWentieth Century: Business STRATEGIES IN A SMALL OPEN ECONOMY 166 (2005).

2. See Joost Jonker \& Keetie Sluyterman, At Home on the World Markets: Dutch InTERnational Trading COMPANies From THE 16TH CENTURy UnTIL THE PRESENT 271 (2000) (noting that "from the end of the Second World War until 1960, the growth of world exports in US dollars averaged $6 \%$ a year" due in large measure to removal of tariffs through the General Agreement on Tariffs and Trade).

3. Eurodollars are "originally deposited in US banks that are acquired by persons resident outside the United States and held abroad, mainly in Europe. Eurodollars are used by foreign banks as a method of financing loans to other local or foreign banks or to commercial borrowers." Organisation for Economic Co-operation and Development, Glossary of Tax Terms, http://www.oecd.org/document/29/0,3343,en_2649_34897_33933853_1_1_1_1,00.html\#E; see also Richard C. Marston, American Monetary Policy and the Structure of the Eurodollar Market, 34 PRINCETON STUD. INT'L FIN. 3, 3 (1974) ("The Eurodollar deposit has been the preferred medium for much short-term investment. The Eurodollar market has attracted funds previously committed only to domestic markets by offering yields that were at times far in excess of those available domestically.").

4. A Treasury official described the typical structure as involving: (1) a Netherlands Antilles subsidiary of a U.S. parent corporation; (2) an American parent that contributes $33-50 \%$ of the amount of debt to be issued as capital; (3) the subsidiary that borrows funds from foreign lenders, with the loans guaranteed by the U.S. parent and the interest payments to be net of U.S. and Antilles taxes; (4) the money is then lent back to the U.S. parent on similar terms and conditions at a slightly higher interest rate; and $(5)$ with the bonds sold by the subsidiary not listed with the S.E.C., sold only to foreign buyers, and in bearer form. Tax Evasion Through the Netherlands Antilles and Other Tax Haven Couniries: Before the Subcomm. of Commerce, Consumer, and Monetary Affairs of the Comm. on Government Operations H.R., 98th Cong. 275-76 (1983) [hereinafter 1983 Tax Evasion Hearings] (statement of John E. Chapoton, Assistant Secretary for Tax Policy, Department of Treasury). There would be: no U.S. or Antilles tax on the sale, redemption, or other disposition of the bonds and no estate tax in either jurisdiction if the bonds were owned by a non-resident of the Antilles. The parent would receive a foreign tax credit for the tax paid on the profit from the spread between the interest rates, and the parent would receive the foreign source income on the profit from the spread which could be used to make use of otherwise excess foreign tax credits. Id. at 277. Some accounts attribute the structure to Anton Smeets. See id. at 787 (in the 1960s Smeets found an opportunity "to get back into his old specialty" doing finance subsidiaries in the Antilles). 
payments made by U.S. borrowers to foreign persons, ${ }^{5}$ and the low rates of tax or outright tax exemption that applied to interest payments made by U.S. borrowers to residents of the Netherlands Antilles. ${ }^{6}$ As we discuss in greater detail below, interest payments made by a U.S. firm on a Eurodollar loan to, say, a Venezuelan investor in the 1970 s, would have been subject to a thirty percent U.S. withholding tax. Under the terms of the tax treaty between the United States and the Netherlands Antilles in force between 1955 and 1987, however, no such tax would have applied to those interest payments if they were made to an investor resident in the Antilles. Since under U.S. law, corporations are legally resident where they are incorporated, the

5. As a practical matter, once income leaves the United States it is virtually impossible for the United States to collect tax on the income. To effectively tax such income, the United States requires payors of such income to withhold tax from any payments made to foreign persons and remit it to the U.S. Treasury. See I.R.C. $\$ 1441$ (mandating that "all persons ... having the control, receipt, custody, disposal, or payment of any ... income ... of any nonresident alien individual or of any foreign partnership shall ... deduct and withhold from such items a tax equal to 30 percent thereof"). However, as a practical matter, the amount of tax, and therefore the amount of deduction, is dependent on specific provisions of bilateral treaties between the United States and many other countries. See, e.g., Convention for the Avoidance of Double Taxation and the Prevention of Fiscal Evasion with Respect to Taxes on Income, U.S.-Neth., art. 10, Sept. 18, 1992, 32 I.L.M. 457 (providing for a maximum $15 \%$ tax on dividends paid to nonresident aliens); see also U.S. DeP'T OF TREASURy, InTERnAl ReVEnue SeRV., Publication No. 519, U.S. TAX GUIDE FOR ALIENS 43-54 (2007), available at http://www.irs.gov/pub/irs-pdf/p519.pdf (instructing nonresident aliens on common exceptions granted in tax treaties; and providing references to individual treaties and resources, and instructing nonresident aliens to file form W-8BEN with a withholding agent to correct a payor withholding an amount greater than that provided by treaty).

6. The island of Curaçao has been a part of a number of jurisdictional groupings as the Netherlands has attempted to find an appropriate organizational structure for its Caribbean possessions. These groupings have included Curaçao, the other five islands, and Suriname, as well as just Curaçao and the other five islands. On Jan. 1, 1986, Aruba left the Antilles and established a separate, direct relationship with the Kingdom government. GerT OOSTINDIE \& IngE KLINKERS, DeCOLONising THE CARIBbEAN: DutCh Policies in A COMPARATIVE PERSPECTIVE 128 (2003). At a date yet to be determined (originally scheduled for Dec. 15, 2008), the Netherlands Antilles will cease to be an entity; Curaçao and Sint Maarten will become separate countries within the Kingdom, and Bonaire, Sint Eustatius, and Saba will become special status municipalities of the Netherlands. See Press Release, Government of the Netherlands, Agreement on Division of Netherlands Antilles (Feb. 13, 2007) [hereinafter Government of the Netherlands, Netherlands Antilles], available at http:/www.government.nl/News/Press_releases_and_news_items/2007/February/Agreement_on_division_ of_Netherlands_Antilles; Press Release, Government of the Netherlands, Curaçao and St. Maarten to have Country Status (Mar. 11, 2006) [hereinafter Government of the Netherlands, Curaçao], available at http://www.government.nl/News/Press_releases_and_news_items/2006/November/Cura_ao_and_St_Maart en_to_have_country_status; Gino Bernadina, Consensus, But no Date Set for New Status, THE DAILY HERALD (St. Maarten), May 23, 2008, available at http://www.thedailyherald.com/news/daily/k006/steer006.html; Dutch Make Available Over 1 Billion Guilders, THE DAILY HERALD (St. Maarten), Feb. 13, 2007, available at http://www.thedailyherald.com/news/daily/j226/accor226.html ("St. Maarten will become a country and the three "smaller" islands Bonaire, Saba and St. Eustatius overseas municipalities."); Stephanie van den Berg, Curaçao Votes for More Autonomy, CARIBBEAN NET NEWS, Apr. 11, 2005, available at http://www.caribbeannetnews.com/2005/04/11/autonomy.shtml (describing vote for "Status Aparte" in Curaçao); Economist Intelligence Unit, Netherlands Antilles, VIEWSWIRE (2009), available at http://viewswire.eiu.com/index.asp?layout=VWcountryVW3\&country_id $=1330000333 \&$ rf $=0$ (noting new date of Jan. 1, 2010 had been agreed for dissolution of Antilles, but now is likely to be pushed back a year). The six islands have had multiple names with both the island of Curaçao and the entire group known as Curaçao until 1949, and then as the Netherlands Antilles (including Aruba until that island withdrew). In the interest of clarity, we will use "Curaçao" to refer to the island of Curaçao and "Netherlands Antilles" or "Antilles" to refer to the larger entity of islands within the Kingdom of the Netherlands to which Curaçao belongs, even when it may not be historically accurate to use the term "Netherlands Antilles." 
Venezuelan investor could form an Antilles N.V.' that would, as an Antilles resident, qualify for treaty benefits. The Antilles N.V. could then deduct the money it paid to the Venezuelan investor, leaving little to be taxed in the Antilles. This difference in legal rules prompted the formation of Antillean companies to function as conduit "recipients" of U.S. interest payments in what was referred to as an "Antilles sandwich" structure. This strategy made lending money to U.S. corporate borrowers economically appealing to foreign investors ${ }^{8}$ and, as such lending-generally known as the "Eurobond" market" - grew, helped relieve the U.S. balance of payments problems. With strong initial encouragement from the U.S. Treasury, the structure flourished into the mid- $1980 \mathrm{~s}^{10}$ and provided a tremendous boon to the Antilles economy.

7. F.J.W. Löwensteyn, Legal Persons, in INTRODUCTION TO DUTCH LAW FOR FOREIGN LAWYERS 125, 131-32 (Jeroen Chorus et al. eds., 2d ed. 1993) (explaining that "N.V." is the abbreviation for "naamloze vennootschap," literally "anonymous partnership," the Dutch term for a public limited liability corporation).

8. 1983 Tax Evasion Hearings, supra note 4, at 168 (statement of Robert Butcher, Vice President, Citicorp) ("The existence of the 30 percent U.S. withholding tax on interest payments to foreign investors effectively eliminates direct access of U.S. corporate borrowers to these foreign markets and necessitates indirect access through the Netherlands Antilles finance subsidiaries.").

9. A Eurobond is an "international bond issued by a company in a market other than its domestic market. Eurobonds may take the form of loans, debentures or convertible debentures, and may be designated in any currency." Organisation for Economic Co-operation and Development: Centre for Tax Policy and Administration, Glossary of Tax Terms, available at http://www.oecd.org/document/29/0,3343,en_2649_34897_33933853_1_1_1_1,00.html\#E. Eurobonds were not exactly the same as bonds sold in the U.S. market:

Eurobond buyers want bearer bonds, annual coupons, front-end discounts, maturities bunched in the 5- to 7-year range, tighter call provisions, better credits. They are historically more interested in floating rate notes and warrants than U.S. investors. In addition, they require that any interest paid must be "grossed up" by the borrower in the event of the imposition of a Netherlands Antilles or U.S. withholding tax on the interest payments.

1983 Tax Evasion Hearings, supra note 4, at 169 (statement of Robert Butcher, Vice President, Citicorp). See also 1983 Tax Evasion Hearings, supra note 4, at 203 (statement of Marshall J. Langer, Attorney of Counsel, Shutts \& Bowen) (defining Eurobond market as international bond market traditionally free of taxes where borrower must pay any tax imposed on interest payments). Paying the withholding tax would dramatically increase the effective interest rate for U.S. borrowers. For example, if the bond market called for $10 \%$ interest and the $30 \%$ withholding tax applied, the U.S. borrower would need to pay an effective interest rate of $14.3 \%$ to provide the foreign lender with a net $10 \%$ rate since the additional payment of the tax would itself be a taxable amount. Id. The Netherlands Antilles allowed bearer bonds, a feature not available in the United States. Bearer bonds and shares are owned by whoever holds them, as contrasted with securities that have registered owners. This makes such instruments similar to cash in terms of owner anonymity. See BlaCK's Law Dictionary 190 (8th ed. 1999) (defining bearer bonds); MARShall J. LANGer, HOW TO USE Foreign TAX HAVENS 101-02 (Practising Law Institute, 1975) (defining bearer shares).

10. By 1979 , new issues in the Eurobond market reached $\$ 17.2$ billion (with $\$ 10.4$ billion denominated in dollars), a considerable sum compared to the U.S. corporate bond market that had $\$ 24$ billion in new issues in that year. By 1982, the Eurobond market had reached $\$ 48.9$ billion (with $\$ 39.1$ billion in dollars) relative to a U.S. corporate bond market of $\$ 33.5$ billion. 1983 Tax Evasion Hearings, supra note 4, at 175 (statement by Butcher, Vice President, Citigroup). A study estimated the current market value of U.S. finance subsidiaries' Eurobond offerings through the Netherlands Antilles at $\$ 20-25$ billion in 1981. 1983 Tax Evasion Hearings, supra note 4, at 585 (excerpts from a report by Taxecon Associates). One estimate put Eurobond volume at $40-50 \%$ of all U.S. corporate bonds in the early 1980 s. A Treaty That May Sink Havens, BUS. WK., Feb. 14, 1983. 
Concern grew within the United States about use of the U.S.-Netherlands Antilles treaty by non-Antilles residents because such use impacted the United States' ability to negotiate tax information agreements with third countries and resulted in lost tax revenues. This concern, combined with a desire to make direct access to the Eurobond market available, ultimately led the United States to eliminate the withholding tax on interest payments made to foreign lenders, which rendered the interest withholding provision of the U.S.-Netherlands Antilles tax treaty unnecessary. Shortly thereafter, the United States terminated the tax treaty itself, leaving nothing in its stead but a grandfathering period for certain outstanding bond issues. When the difference in the U.S. legal regime toward Antilles lenders went away, the bulk of the Antilles financial intermediation sector was wiped out. Because of rigidities in the Antilles' governance structure, the jurisdiction failed to adapt in time to the changes in U.S. attitudes and did not develop substitute financial intermediation and regulatory arbitrage products to replace the Antilles sandwich structures before its demise. The Antilles had had such opportunities, having served as the legal residence of hedge funds ${ }^{11}$ beginning in the 1960 s and experimenting with captive insurance prior to the tax treaty's cancelation.

The rise and fall of the Antillean financial intermediation business provides insight into the current struggles between onshore and offshore governments over the role of offshore financial centers like Barbados, Bermuda, the Cayman Islands, the Channel Islands, Hong Kong, the Isle of Man, Liechtenstein, Mauritius, Singapore, and Switzerland in the global economy. With France, Germany, and the United States pressing for major changes in offshore jurisdictions' legal and regulatory regimes, ${ }^{12}$ one likely avenue by which these governments may seek to pressure offshore governments is by moving to eliminate opportunities for such arbitrage. How offshore financial centers react, and whether they have learned the lessons of the Antillean experience, will play a major role in determining the shape of the offshore financial sector and which jurisdictions will be successful.

The fate of the Antilles suggests four critical propositions for the offshore financial sector at large that we explore in depth in this article. First, there will always be differences among legal regimes, and those differences often may be arbitraged to make business transactions more cost-efficient. This arbitrage may be financially beneficial to the parties to the transactions and to the jurisdictions in which the transactions take place. The immediate fiscal benefits of the form of financial intermediation involved in the Antilles sandwich flowed primarily to the Antilles, which derived a considerable portion of its government revenue from the offshore financial sector. ${ }^{13}$ The United States, however, also benefited because U.S.-

11. A hedge fund is a largely unregulated investment fund geared toward sophisticated individual and institutional investors that actively trades a range of financial instruments and typically compensates its management with both a fixed management fee and a percentage of profits. See Houman B. Shadab, The Law and Economics of Hedge Funds: Financial Innovation and Investor Protection, BERKELEY BUS. L.J. (forthcoming 2009), available at http://papers.ssrn.com/sol3/papers.cfm?abstract_id=1066808 ("A hedge fund is a private investment pool not subject to the full range of restrictions on investment activities and disclosure obligations imposed by the federal securities laws, that compensates management in part with an annual performance fee, and typically engages in the active trading of financial instruments.").

12. See ORG. For ECON. Co-Operation and Dev. [OECD], Towards Global Tax Cooperation: Progress IN IDENTIFying and Eliminating Harmful Tax Practices 7 (2000) (discussing how interested parties and entities like OECD are working toward improving legal and regulatory norms for offshore jurisdictions).

13. 1983 Tax Evasion Hearings, supra note 4, at 64 (statement of William J. Anderson, Director, General Government Division, General Accounting Office) (reporting that the Antilles Central Bank 
based companies operating abroad gained access to cheaper foreign capital and thus, became increasingly competitive.

A second proposition is that while differences in general among legal regimes are persistent, any particular difference is fluid, which makes the revenue flows realized by jurisdictions engaged in financial intermediation particularly vulnerable to elimination through changes in both business conditions and in the legal regimes that produce intermediation opportunities. Even large jurisdictions are vulnerable to the effects of changes in other jurisdictions' laws, though those effects may not be as damaging. This is as true for the United States in its role as an offshore financial center as it is for the Antilles and other jurisdictions more typically thought of as offshore financial centers. To the extent that the United States serves an offshore role for Latin American or Asian investors, it, too, is susceptible to changes in those countries' tax and regulatory laws. ${ }^{14}$

Third, the vulnerability of offshore jurisdictions to the elimination of revenue flows from financial intermediation activity places a premium on a jurisdiction's legislative agility. To survive in a world of perpetual change, an offshore jurisdiction must develop the ability to adapt quickly. Fourth, whether an offshore jurisdiction can adapt to variations in business conditions and alteration in the onshore legal regimes depends greatly on its own laws and its own political arrangements.

In this Article, we examine the history of the Netherlands Antilles' offshore financial sector and use that jurisdiction's experience as a lens through which to examine the way that changes in onshore jurisdiction law and the international regulatory climate may affect other international financial centers, both onshore and offshore. In Part I, we provide the first comprehensive account of the Antilles' early economic history, an important contribution given the historic role played by the island's financial sector in the overall development of offshore finance. Part II describes the arc of the Antilles reign as an offshore financial intermediation powerhouse, which finally ended with the repeal of the U.S.-Netherlands Antilles tax treaty. In Part III, we develop our theory of "regime plasticity" 15 and the role that it plays in allowing offshore financial centers to adapt to changes in the legal and political environments where they operate. We also evaluate the response of the Antilles' to the collapse of its financial sector in light of this theory. Part IV concludes the article by offering an assessment of the future roles of offshore

calculated that taxes from offshore activities in 1981 accounted for $16 \%$ of total tax receipts); see Interview with Gregory Elias, United Trust Co., Curaçao, Netherlands Antilles (May 22, 2008) [hereinafter Interview, Elias, United Trust Co.] (stating that $60 \%$ of government revenue derived from offshore sector in the mid-1980s).

14. See Craig M. Boise, Regulating Tax Competition in Offshore Financial Centers, in REGULATORY COMPETITION AND OFFSHORE FinANCIAL CENTERs (Andrew P. Morriss ed., forthcoming 2010) (explaining that for smaller jurisdictions, the relative magnitude of the impact of changes by onshore jurisdictions is much greater than it is for large diversified economies like that of the United States).

15. The term "plasticity" generally refers to the capability of an object to be molded and retain its shape after change. Merriam-Webster Online Dictionary, at http:/www.merriamwebster.com/dictionary/plasticity ("[T]he ability to retain a shape attained by pressure deformation."). Interestingly, the meaning of plasticity in the context of brain function is particularly apt for our purposes in delineating the ability of offshore jurisdictions to respond to change. See id. at http:/www2.merriamwebster.com/cgi-bin/mwmednlm?book=Medical\&va=plasticity ("[T]he capacity for continuous alteration of the neural pathways and synapses of the living brain and nervous system in response to experience of injury that involves the formation of new pathways and synapses and the elimination or modification of existing ones.") (emphasis added). 
financial intermediation jurisdictions, onshore jurisdictions, and multilateral institutions within the global economy, particularly in light of recent negative attention to offshore financial centers around the globe.

\section{ECONOMIC UNDERPINNINGS}

Europeans Alonso de Ojeda and Amerigo Vespucci first visited Curaçao, one of the Caribbean islands that comprise the Netherlands Antilles, in $1499 .{ }^{16}$ It was not until 1527, however, that the Spanish finally settled the island, ${ }^{17}$ making it part of the Spanish Empire for more than a hundred years until it was ceded to the Dutch in 1634. ${ }^{18}$ Except for a brief period of British rule during the Napoleonic wars, the island has since remained a part of the Kingdom of the Netherlands, albeit under a surprisingly diverse series of constitutional arrangements and as part of a shifting cast of other Caribbean islands and territories colonized by the Dutch. ${ }^{19}$ In this section we describe the rise of Curaçao's financial sector, beginning with its early economic activities and continuing through the hey-day of the island's financial intermediation activity in the late 1970s. This early history explains why the factors necessary for the development of offshore financial activity appeared in Curaçao and sheds light on the reasons why Curaçao was among the first jurisdictions to develop a substantial offshore sector.

\section{A. "A Lonely Island"20}

The Dutch arrived in the Caribbean not for religious or ideological reasons, but with "the hope of making their fortunes and to establish themselves as a prominent nation." " Yet the islands they colonized were not obvious choices to advance either goal. Indeed, the six islands that became first Curaçao and later the Netherlands Antilles were not highly sought after by European powers. ${ }^{22}$ The Spanish called them islas inútiles, or "useless islands," resistance to the Dutch in $1634 .^{24}$ Living up to its Spanish nickname, colonial Curaçao provided the Dutch with little in the way of agricultural or natural resources. ${ }^{25}$ The one local industry that did develop was salt production, which

16. See Curaçao, in COLUMBIA ENCYCLOPEDIA 727 (6th ed. 2007).

17. See id.

18. See id.

19. Id. See also Netherlands Antilles, in COLUMBIA ENCYCLOPEDIA 1988; see generally J. HARTOG, CURAÇAO: FROM COLONIAL DEPENDENCY TO AUTONOMY (1968) (providing an overview of the history of Curaçao and the influence of the Dutch on the island).

20. Herdman F. Cleland, Curaçao, a Losing Colonial Venture, 41(3) BULL. OF THE AM. GEOGRAPHICAL SOC'Y 129, 138 (1909).

21. Gert Oostindie, Paradise Overseas, The Dutch Caribbean: Colonialism and its TRANSATLANTIC LEGACIES 4 (2005).

22. Id. at 2 .

23. Id. at 5 .

24. Philip Hanson Hiss, Dutch West Indies: Curaçao and Surinam, in THE NETHERLANDS 392, 392, 396 (Bartholomew Landheer, ed. 1943).

25. OOSTINDIE, supra note 21, at 8 ("The Leeward Islands were simply too dry for large-scale cultivation of tropical export crops; crop production and goat breeding never really developed beyond local supply."); Philip Hanson HISS, NeTHERlands AMERICA: THE DUTCH TERRITORIES IN THE WEST 119 (1943) ("Agriculture on Curaçao was limited to the cultivation of aloes, divi-divi pods for tanning, and a small number of oranges which were used in the manufacture of the well-known Curaçao 
helped the Dutch break Spain's monopoly on that commodity. ${ }^{26}$ This turned out to be too little to make the colony prosper, however, and after only ten years the Dutch gave serious consideration to abandoning their new possessions. ${ }^{27}$ An early Dutch observer concluded that

[o]ne cannot describe the island of Curaçao as a treasure trove of the most valuable products of nature: its entrails are not pregnant with gold, silver or gems, and its fertile plains, between rocks and stony ground, produce little that is exceptional; all that grows and waxes is usually for personal use or to feed the Negro slaves. This island can therefore be regarded as a warehouse, or supply shed, for products that are shipped from the mainland or the Netherlands, or any land out of whose lap Europe enjoys notable benefits. ${ }^{28}$

Even today, a visitor is likely to be struck by the contrast between other, more lush Caribbean islands and the arid terrain filled with cacti and other desert plants that characterizes the bulk of Curaçao's topography. ${ }^{29}$

Lacking natural resources, the island's economy was almost entirely dependent on trade and its importance lay in its harbor and its proximity to major trade routes. ${ }^{30}$ The growth of trade, together with religious toleration, brought to Curaçao a large colony of Sephardic Jews almost from the beginning of Dutch colonization, who founded merchant houses that eventually came to be known as the "Little Rothschilds" of the Caribbean, and helped establish the island as an early financial hub. $^{31}$ Indeed, the Dutch willingness to disregard religious and political differences in

liqueur."); FUAT M. ANDIC \& SUPHAN ANDIC, GOVERNMENT FINANCE AND PlanNED DEVELOPMENT: FISCAL SURVEYS OF SURINAME AND THE NETHERLANDS ANTILLES 175 (1968) ("Agriculture has never been important in the Netherlands Antilles.").

26. Kenneth Gordon Davies, The North Atlantic World in the Seventeenth Century . 44 (1974) ("In 1634 [the Dutch] took Curaçao from Spain, wanting it for its salt. ...").

27. Pieter Emmer, The Dutch In THE ATlantic ECONOMY, 1580-1880: Trade, Slavery and EMANCIPATION 101 (1998).

28. J.H. HERING, BESCHRIJVING VAN HET EILAND CURAÇAO, EN DAAR ONDER hOORENDE EILANDEN BON-AIRE, OROBA, EN KLEIN CURAÇAO 57 (1779) quoted and translated in OOSTINDIE, supra note 21 , at 5-6.

29. A Wall Street Journal report on the offshore sector in the late 1980s termed the island "a harsh landscape of rock" with wind "so fierce and unremitting that the best-known piece of nature may be the divi-divi tree, which looks like an upside-down L; its branches grow straight out to one side, saving the wind the trouble of having to blow them that way." Charles F. McCoy, Netherlands Antilles Minus a U.S. Treaty is Tax-Paradise Lost-Faced with Cancellation, Locals Seek Alternatives, WALL ST. J., July 28, 1987, $\S 1$. The island also played a minor role in Rachel Carson's Silent Spring, featured as the location of a successful screwworm eradication program using sterilized male screwworms. The island was selected for the program because of its isolation. See RACHEL CARSON, SILENT SPRING 280-82 (1962).

30. Cleland, supra note 20 , at 130 (stating the harbor is "a remarkable one" and that a 1909 observer noted the bay "is said to be large and deep enough to shelter the largest navy in the world."): Hiss, supra note 25, at 50-51 (noting the prosperity of Curaçao was based on trade although there was some agriculture); OOSTINDIE \& KLINKERS, supra note 6, at 58 (remarking that Curaçao "fulfilled a vital function as points of connection for trade-both legal and illegal-within the Caribbean region."). OOSTINDIE, supra note 21, at 2 (noting the Dutch West Indies did break the Spanish monopoly on salt and provide Holland with a vital source of salt, critical to the herring industry in the Netherlands).

31. Cornelis Christiaan Goslinga, Curaçao and Gúzman Blanco: A Case Study of Small POWER POlitics In the CaribBean 12 (1975). See also HiSS, supra note 25, at 401 (discussing role of Portuguese Jewish community). 
trade gave them a great advantage over their European competitors. As a colonial governor of the British colony of Jamaica noted, perhaps enviously, the Dutch believed that "Jesus Christ was good, but trade was better."

During the 1700 s, Dutch slave traders made a substantial contribution to Curaçao's wealth by bringing slaves to Curaçao and then selling them in South America and the Caribbean. ${ }^{33}$ Moreover, Curaçao proved an important conduit through which flowed: Dutch capital to fund the Caribbean sugar industry's growth; Dutch shipping to carry refined sugar; Dutch technical assistance to improve sugar production quality; and Dutch merchants to provide the luxury goods the newly rich planters in other European nations' Caribbean colonies could now afford ${ }^{34}$ Apart from the slave trade, Curaçao's location close to modern day Venezuela and Colombia offered opportunities for circumventing the Spanish (and later Venezuelan and Colombian) restrictions on trade with outsiders, and for avoiding customs duties. $^{35}$ In what might be viewed as an early example of offshore financial activity, Dutch privateers based on Curaçao harassed Spanish treasure fleets throughout this period. ${ }^{36}$ Recognizing the importance of trade, the Dutch abandoned the mercantilist trade regime by 1675 and declared Curaçao a free port. ${ }^{37}$ In sum, Curaçao's colonial legacy was that of a trading center facilitating metropolitan involvement in the New

32. EMMER, supra note 27 , at 101.

33. Cornelis ChristiaAn Goslinga, A Short History of THE Netherlands ANTILlES AND SURINAM 35 (1979), 110-11; EMMER, supra note 27, at 27, 55 ("Illegal but tolerated" imports of slaves via Curaçao were an important source of labor for Spanish America after 1640. As the height of the slave trade, slaves made up half the population of the colony.); Hiss, supra note 25, at 401 ("[T] he wealth of Curaçao [in the eighteenth century] . . lay in its commerce in goods and slaves."); PAUL BLANSHARD, DEMOCRACY AND EMPIRE IN THE CARIBBEAN: A CONTEMPORARY REVIEW 276 (1947) ("It paid Curaçao to be a middleman in the slave trade...."); GosLingA, supra note 31, at 4 (noting the island "served as a slave market and warehouse, providing the Spanish colony [of Veneuzela] with a muchneeded black labor force and many commodities which Spain was unable to provide."). See HARTOG, supra note 19, at 163 (noting the Dutch were successful as slave suppliers to Spanish territories in part because they had access to the necessary capital, while the Spanish did not; another example of an early "offshore" role for the island).

34. Melvin H. JACKSON, Salt Sugar, AND SlaAves: The DutCH IN THE CARIBbEaN, 14-15 (1965) ("Behind the scenes of this revolution [introduction of sugar cane], the Curaçaoans were ubiquitous. Backed by Amsterdam capital, they arranged for the credits needed to set up in the new industry: vats, boilers and caldrons were offered at attractive financing. Dutch technicians, trained in Brazil, were available for consultation to provide the necessary instruction to ensure a fine product. Omnipresent Dutch shipping was at hand to carry off the product, relieving planters of marketing worries .... The warehouses at Willemstad expanded their stores of European staples and luxuries for the increasingly prosperous and fastidious planter class ....").

35. GOSLINGA, supra note 33 , at 35 ; BLANSHARD, supra note 33 , at 276 ("[I]t has always paid the more daring merchants of the island to smuggle goods into South America."); OOSTINDIE, supra note 21, at 9 " Curaçao and Saint Eustatius ... were especially important to trade within the Caribbean and between the Caribbean and the mainland. This trade was mainly smuggling, as hazardous as it was potentially profitable for merchants and the opportunistic colonial power."); GOSLINGA, supra note 31, at 4 ("[T]rade relations [with Venezuela], although largely illicit, ... were the source of its prosperity in the seventeenth and eighteenth centuries."); HISS, supra note 25 , at 51 ("[T] he vast majority of European goods and American produce was carried in Dutch bottoms . . . for the colonists [in the entire West Indies] rightly refused to abide by the ordinances of governments in Europe that were interested in the West Indies colonies only for the money they could get out of them....").

36. GoSLINGA, supra note 33, at 21 ; OOSTINDIE, supra note 19 , at 2 (noting that "[t]he distinction between war and piracy at that time was a vague one"); Hiss, supra note 25 . at 53-54 (discussing privateering at Curaçao); JONKER \& SLUYTERMAN, supra note 2, at 50 (stating privateering was "the most profitable" activity in Dutch West Indies in early 17 th century).

37. EMMER, supra note 27, at 77. 
World. ${ }^{38}$ In this role, Curaçao prospered from the late seventeenth century through the end of the eighteenth century. ${ }^{39}$

However, Curaçao's affluence faded in the nineteenth century. A local history describes the period from 1816 through 1916 as "years of bitter poverty" with "very few exceptions." ${ }^{40}$ Moreover, as the nineteenth century progressed, technological advances in shipping made Curaçao less necessary as a provisioning stop for transAtlantic shipping." By the close of the nineteenth century, the capital of Willemstad "on dry, barren Curaçao, was a desolate "entrepot for traders", and the entire colony was viewed as "a liability to the Dutch government." consideration was given to selling or simply abandoning the island. ${ }^{44}$ Overshadowed within the Caribbean region by the Dutch mainland colony of Suriname and globally by the vastly larger Dutch colony of Indonesia, the Dutch Caribbean islands became little more than an afterthought for the Kingdom of the Netherlands. ${ }^{45}$ As a result, in

38. In addition to its role as a trading center, the island has served as a political refuge for Venezuelan revolutionaries at various times. Cleland, supra note 20, at 138 (noting that "Bolivar, Paez, Miranda, Sublet, Guzman Blanco, Riero and other Venezuelan 'revolutionists' have spent their leisure time [in Curaçao] making plans for future action").

39. Albert L. Gastmann, The Politics of Surinam and the Netherlands Antilles 10 (1968) (describing how the island had "vast economic importance and richness in the eighteenth century" while the slave trade flourished).

40. Hartog, supra note 19, at 267; Bernard L. POOle, The CaribBean Commission: BACKGROUND OF COOPERATION IN THE WEST INDIES 131 (1951) (noting that the end of the slave trade in 1863 was thought to have ruined the prosperity of the islands); GOSLINGA, supra note 31 , at 85 (stating that the way emancipation proceeded in the Dutch West Indies illustrates the Dutch lack of concern with their West Indian colonies). HISS, supra note 25, at 107 (noting that the Dutch emancipated their slaves only on July 1,1863 ). As Oostindie and Klinkers note:

\begin{abstract}
It was not until the beginning of the 1850 s that the Crown, the Ministry of Colonial Affairs and the Dutch parliament came to recognize that the institution of slavery could not be upheld much longer - if only because it made the Netherlands look increasingly backward. Even though this was the first occasion that the Dutch government had become seriously concerned with its West Indian colonies, it would take another ten years before slavery was finally abolished in 1863-long after England (1834) and France (1848) had taken this step. This was mainly due to the thorny problem of the compensation to be paid-to the slave owners, that is, not to the slaves.
\end{abstract}

OOSTINDIE \& KLINKERS, supra note 6, at 59.

41. HISS, supra note 25 , at 119.

42. An "entrepot" is "a building or place where goods from abroad may be deposited and from which those goods may then be exported to another country without paying a duty." BLACK'S LAW DiCTIONARY 574 (8th ed. 2004).

43. GASTMANN, supra note 39, at 9-10 ("Economically, politically and strategically these islands had .. lost their importance by the nineteenth century."); GoSLINGA, supra note 31, at 85 ("The island's economy never really recovered from British occupation during most of the Napoleonic Wars.").

44. GOSLINGA, supra note 31, at 85-88, 93-94; OOSTINDIE \& KLINKERS, supra note 6, at 59.

45. BLANSHARD, supra note 33, at 274 ("To Hollanders the Dutch investment in the Caribbean is trivial compared to the two billions invested in the East Indies."); GoSLINGA, supra note 31, at 9 (noting that by the nineteenth century, "[t]he West Indian colonies formed by a tiny part of the Dutch colonial empire, which contributed no profits to the Dutch treasury, and required subsidies"); Hiss, supra note 24, at 393 ("The recent tendency ... has been to discount the importance of the West Indies and to stress the wealth and glamor of the East Indies."); OOSTINDIE, supra note 21, at 6-7 (noting that "the Dutch West Indies rarely emerged from the shadow of the Dutch East Indies"); OOSTINDIE \& KLINKERS, supra note 6, at 62 (explaining that the Antilles and Suriname were "small and problematic possessions very far away geographically and culturally" and were "completely overshadowed by the Dutch-East Indies relationship" during decolonization). 
the words of the preeminent historians of Dutch colonial policy, the Dutch policies in the Caribbean were "rather uninspired and fairly inactive" and the Dutch Caribbean colonies never rose above "the status of 'poor cousin' to the Dutch East Indies."

In addition to the end of the slave trade and technological advances in shipping, a third major reason for Curaçao's nineteenth century decline was its difficult relationship with Venezuela, "on which it was largely [economically] dependent." "Curaçao's role as a commercial intermediary between Venezuela and the outside world was almost completely eliminated" in the early nineteenth century by the combination of the Dutch government's retreat from free trade and reliance on tariffs, "long after all the other Caribbean powers had opened their ports to free trade," $1828{ }^{50}$ Curaçao traders suffered greatly when, in an effort to punish the Dutch colony for failing to control or expel its political exiles living there, Venezuela adopted a higher tariff on goods shipped to its ports from Curaçao than from elsewhere. ${ }^{51}$

By 1909, Curaçao's decline had advanced to the point that an article describing the island could credibly be entitled "Curaçao, a Losing Colonial Venture," and conclude that "Curaçao will in time be obliged to yield to the inevitable and take the place that her geographic position and climatic conditions have ordained - a lonely island, with little political or commercial importance, and a small and poor population." "52 What little remained of the island's earlier economic prosperity came from sales to Venezuelans who visited Curaçao's free port "to trade and take their chances on being able to smuggle their purchases through the Venezuelan custom houses." 53 The depths of Curaçao's economic troubles during this period are evidenced by the fact that the only notable local industrial activities were production of women's straw hats (for which even the thatch was imported) and fishing. ${ }^{54}$ The advent of World War I failed to revive Curaçao's flagging economic fortunes, ${ }^{55}$ and, in fact, the war brought further stagnation of trade despite the Netherlands' neutrality. ${ }^{56}$ Shipping at Willemstad fell from 1,500 ships and 2,800,000 tons in 1913

46. OOSTINDIE \& KLINKERS, supra note 6, at 57.

47. HARTOG, supra note 19 , at 278-79.

48. GOSLINGA, supra note 31 , at 4 .

49. HARTOG, supra note 19 , at 278-79 (referring to Venezuelan duties and tariffs).

50. HISs, supra note 25, at 118; HARTOG, supra note 19, at 247-48. The various port duties were abolished first in 1826 but the governor had "set his mind against the abolition of the port-dues" and undercut the policy by instituting a "safety tax" that equaled the abolished taxes in amount. Id. The new tax was not abolished until the end of 1827. Id.

51. Goslinga, GúzMAN BLANCO, supra note 32, at 97-99 (describing deliberate Venezuelan use of differential tariff to harm Curaçao); id. at 103 (describing impact of duties, reducing Curaçao's imports from over 5.5 million guilders in 1880 to just over 3.1 million in 1883 , leading to an exodus by merchants).

52. Cleland, supra note 20 , at 138 .

53. Id. at 134,138 (relating how Dutch subsidies of $\$ 150,000-\$ 200,000$ per year were necessary in the early 20 th century); GOSLINGA, supra note 31 , at 85 (noting that subsidies in 1868 alone were 200,000 guilders and the total between 1867 and 1881 was over 2,200,000 guilders); see also GoSLINGA, supra note 33, at 127-30 (describing importance of legitimate trade with Venezuela in 19th century and conflicts with Venezuela); id. at 137 (describing how a $30 \%$ tariff introduced by Venezuela in the 1880 s on goods from the island but not elsewhere "hurt Curaçao bitterly and would have even more, if smuggling had not risen to the task and taken over much of the regular trade before long").

54. GoSLINGA, supra note 33 , at 132 .

55. See id. at 144 (discussing the war's impact on trade and creation of supply shortages).

56. Id. 
to 248 ships and just over 680,000 tons in $1918 .^{57}$ As a result, subsidies from the Netherlands to Curaçao became increasingly necessary and reached a million guilders in $1919^{58}$ (roughly US $\$ 6.7$ million today). ${ }^{59}$ Not surprisingly, Dutch colonial policies were soon primarily focused on "reducing financial loss."

Curaçao and the other Dutch Caribbean islands likely would have "remained forgotten"61 but for the 1914 discovery of oil at Venezuela's Lake Maracaibo. ${ }^{62}$ This discovery alone would have had little impact on Curaçao were it not for the need for a facility to refine the Venezuelan oil and the island's possession of two characteristics that made it an appealing location for such a facility. First, Curaçao offered one of the best-protected and most strategically situated harbors in the Caribbean, only forty miles off the coast of Venezuela. ${ }^{63}$ Second, Curaçao's Dutch administration provided a level of political stability that was lacking in Venezuela, which was a crucial concern for an oil company contemplating where to place an enormously expensive fixed asset. ${ }^{64}$ These factors persuaded Royal Dutch/Shell, the Anglo-Dutch oil company, to begin constructing on Curaçao what was at the time one of the world's largest oil refineries. ${ }^{65}$ Begun in 1915, completed in 1918, and brought to full capacity in $1922,{ }^{66}$ the refinery brought to Curaçao "a period of prosperity unparalleled even in the eighteenth century." It created an employment

57. Id.

58. Id. at $144-45$.

59. See, e.g., NationMaster.com, Netherlands Antilles Gulden, http://www.nationmaster.com/ encyclopedia/Netherlands-Antillean-gulden (last visited Nov. 13, 2009) (explaining that the Caribbean islands used a currency based on the Dutch guilder until World War II); International Institute of Social History, Value of the Guilder/Euro, http://www.iisg.nl/hpw/calculate.php (last visited Nov. 13, 2009) (calculating that one Netherlands guilder in 1919 would have been worth $€ 5.16$ in 2006); OANDA.com, FXHistory®: Historical Currency Exchange Rates, http://www.oanda.com/convert/fxhistory (last visited Oct. 11, 2009) (calculating that 1 in 2006 was worth roughly US\$1.28 as of October 11, 2008).

60. OOSTINDIE \& KLINKERS, supra note 6, at 59.

61. GASTMANN, supra note 39 , at 9 .

62. HISS, supra note 25, at 123; POOLE, supra note 40 , at 133.

63. See Cleland, supra note 20 (noting the shape of the harbor and its importance in the island's development); GASTMANN, supra note 39, at 10 (noting that Curacao has one of the best natural harbors in the Caribbean); GoslingA, supra note 33, at 141 (noting that Venezuela "did not seem to be suitable [for a refinery] ... due to the poor facilities characterizing all Venezuelan ports ..."). In addition to Curaçao's other advantages, its location close to Venezuela was crucial because a sand bar at the entrance to Lake Maracaibo prevented large tankers from entering the lake. BLANSHARD, supra note 33, at 278. Curaçao's location also gave it an advantage in shipping refined products to the U.S. and British markets, as the island was 200 miles closer to New York and 800 miles closer to Liverpool than was Houston, Texas, a rival refining center. HARTOG, supra note 19 , at 308 .

64. BLANSHARD, supra note 33, at 278 ("The great European capital interests which rushed to Venezuela in the early stages of its oil boom did not trust the political rulers of that country. They feared revolution or the exaction of undue tributes. ..."); GASTMANN, supra note 39, at 10; GOSLINGA, supra note 33 at 141 (noting that Venezuela "did not seem to be suitable [for a refinery], mainly because of its internal turmoil ..."); Hiss, supra note 24, at 405 ("There was only a small market for petroleum products in Venezuela ... the country was politically unstable ... Curaçao, only a short distance away, suffered none of these defects."); HISS, supra note 25, at 123 (describing problems in Venezuela); OOSTINDIE \& KLINKERS, supra note 6, at 60 ("[T] he islands counted as stable and secure investment areas, unlike the notoriously unstable republic of Venezuela.").

65. For a time in the 1930 s, the Curaçao refinery was the world's largest. BLANSHARD, supra note 33 , at 279 .

66. Hiss, supra note 25, at 124.

67. Goslinga, supra note 33, at 142. See also Hiss, supra note 24, at 406 (describing oil-driven prosperity). 
boom $^{68}$ and, beginning in the mid-1920s, enabled the colony to balance its budget. ${ }^{69}$ By 1929 , government revenue was " 120 percent more than it had been five years before, nearly 187 percent more than it had been ten years before, and almost 540 percent more than it had been fifteen years earlier."70 Importantly, the refinery's need for employees with financial expertise, in addition to technically skilled laborers, brought managers and accountants to Curaçao ${ }^{71}$ and thus gave the island a nascent professional services sector. The sector expanded further when Royal Dutch/Shell relocated the headquarters of its Curaçao Oil Industry Company subsidiary to Willemstad in the $1920 \mathrm{~s}^{72}$

Curaçao's refinery boom stalled with the onset of the Depression in the late 1920s. Half of the plant's employees lost their jobs between 1929 and 1931, and unemployment in general reached 1,300 notwithstanding the departure of some 5,000 people from the island and its workforce. ${ }^{73}$ By 1934, however, good times had returned, ${ }^{74}$ and in 1941 the island had the highest level of imports per capita in the Caribbean. Just before World War II, the future of the island seemed firmly tied to the oil industry; ${ }^{75}$ almost ninety percent of the value of Curaçao's exports in 1937 came from the refinery. ${ }^{76}$ The refinery-driven prosperity brought immigrants from the other Dutch islands and from other Caribbean islands as well, and between 1910 and 1941 the population doubled. ${ }^{77}$

In summary, the first three hundred years of Dutch rule in Curaçao found the island playing a variety of roles: a financial center of sorts, a facilitator of trade, and a stable investment climate in a sea of unstable, post-colonial Latin American regimes. The Netherlands largely ignored Curaçao and the other Dutch Caribbean possessions, particularly in contrast to the much larger and more lucrative Dutch colony of Indonesia, except when the refinery returned prosperity to the island. However, Curaçao's stability, its European and Latin American connections, and its

68. HISS, supra note 25 , at 127 ("[T]here is scarcely a family on either [Curaçao or Aruba] which is not connected either directly or indirectly with the refineries.").

69. GASTMANN, supra note 39, at 16 (stating that the Dutch parliament's approval was needed for deficit budgets, and so the balanced budget decreased Dutch control over Curaçao's affairs); GoSLINGA, supra note 33, at 144-45 (explaining that for the first time since 1816, there was no subsidy in 1924 and the years thereafter, except for 1929 when a Venezuelan rebel group assaulted Fort Amsterdam to get weapons to invade Venezuela).

70. Amry Vandenbosch, Dutch Problems in the West Indies, 9 FOREIGN AFFAIRs 350, 350 (1931). Some complained that the "government is run by the oil companies." HISS, supra note 25, at 128 (claiming it was common to hear this asserted).

71. I. Wagenmaker, Black Gold: The Oil Industries of Aruba and Curaçao, in Holland CARRIES ON: THE NETHERLANDS WEST INDIES 40, 41 (1943) ("The majority of the executives and technicians of the Curaçao refinery are Europeans ..."); Interview with Shulaika Paassen-Delsol, Managing Director, Paassen Delsol, in Curaçao, Neth. Antilles [hereinafter Interview, Paassen-Delsol, Paassen Delsol] (May $21,2008)$.

72. GOSLINGA, supra note 33 , at 142 .

73. Id. at 147, 151 (describing how bad economic conditions led to a lot of outmigration of menseasonal workers in Cuba and Puerto Rico, work in salt pans in St. Kitts, phosphate mines in French Guiana.).

74. See HARTOG, supra note 19, at 353 (stating that in 1934, trade was no longer in decline and the oil industry resumed activities).

75. Hiss, supra note 25 , at 131.

76. Calculated from HISS, supra note 25, app XIV, at 202 (showing that "Petroleum Products" accounted for $266,666,763$ Guilders out of a total of $269,943,953$ Guilders).

77. Hiss, supra note 25 , at 130. 
low transaction costs helped to establish quite firmly the "financial DNA" that would lead to its later success as a jurisdiction engaged in financial intermediation.

As both others and we argue elsewhere, it is no accident that small island jurisdictions (or "virtual" islands on the mainland such as Liechtenstein and Luxembourg) have found a modern role as offshore financial centers. ${ }^{78}$ The limited resources available to small jurisdictions create a need for economic opportunities such as those offered by financial centers. By the same token, the openness to trade that permits small jurisdictions to survive makes them well suited to exploit those economic opportunities. ${ }^{79}$ It certainly was not inevitable that Curaçao would become an offshore financial center, for such development generally depends on factors beyond any single jurisdiction's control. ${ }^{80}$ But it would have been surprising, given its history, if Curaçao had not at least pursued such economic opportunities.

\section{B. The Impact of the Second World War}

World War II played a critical role in establishing Curaçao as an offshore financial center and in the birth of the offshore world generally. ${ }^{81}$ The first consequence of the war was that it brought to the attention of multinational firms the jurisdictional mechanism by which Curaçao would later profit enormously. When the Netherlands was invaded by German forces on May 10, 1940, the Dutch government fled to London and established a government-in-exile. ${ }^{82}$ The German occupation of the Netherlands presented Dutch companies having interests outside of Europe with a two-pronged dilemma. First, some Dutch companies owned assets located in neutral countries, such as the United States at the beginning of hostilities in Europe. ${ }^{83}$ These neutral countries may have frozen or impounded those assets. ${ }^{84}$

78. Dhammika Dharmapala \& James R. Hines Jr., Which Countries Become Tax Havens? 1 (May 2009) available at http://ssrn.com/abstract=952721 (noting that "tax havens are small countries, commonly below one million population").

79. See Boise, supra note 14.

80. $I d$.

81. 1983 Tax Evasion Hearings, supra note 4, at 800 (statement of Harold Henriquez, Minister for the Netherlands Antilles Affairs, Government of the Netherlands Antilles) (explaining that "[t]he international financial sector began just prior to World War II when European companies formed Western hemisphere holding companies to prevent their non-European holdings from falling into enemy hands").

82. James H. Huizinga, Holland in the War, in THE NETHERLANDS (Bartholomew Landheer ed., University of California Press 1943) 411, 412-16 (describing invasion and flight). Following the invasion of the Netherlands, the Dutch Caribbean colonies declared martial law and German shipping and Germans in the colonies were seized. Hiss, supra note 25 , at 164.

83. The United States did not enter the war until December of 1941, some nineteen months after the German occupation of the Netherlands. OOSTINDIE \& KLINKERS, supra note 6, at 44.

84. Within German-occupied territory, Dutch multinational assets were still subject to control by German-dominated entities in the occupied Netherlands. For example, after Royal Dutch relocated its statutory seat to Curaçao:

Reichskommisar A. Seyss-Inquart, the highest civil authority in the Netherlands during the German occupation, picked on a technicality to declare it [the relocation] null and void. Consequently the Verwalter appointed to manage Royal Dutch and Bataafsche [a shipping subsidiary] had full powers to act on behalf of the concern in occupied Europe and in the countries allied to Germany, such as Romania. The Verwalter lost no time in appointing a new general manager, more amenable to the German demands, at Astra Romana, the Group's operating company there and that country's biggest oil producer. 
Second, some Dutch companies' assets were located in Allied belligerent countries such as Britain. These governments certainly would have taken steps to seize control of those assets if there were no mechanism to legally separate the assets from entities in occupied Holland. ${ }^{85}$ Such measures in either circumstance would have hampered Dutch companies when the war ended, since they would have been required to undertake onerous legal measures to regain control of their assets, even as nonDutch competitors were busy rebuilding. On the other hand, the Dutch did not want merely to relocate their remaining assets to other Allied jurisdictions, since they did not want Dutch assets made subject to non-Dutch law during the turmoil of the war. ${ }^{86}$ These twin problems were resolved in part by a Dutch statute that allowed corporations to shift their statutory seats ${ }^{87}$ within the Kingdom of the Netherlands in the event of war, natural disaster, social upheaval and certain other calamitous events. ${ }^{8}$ All that the statute required was that appropriate paperwork be filed in the new jurisdiction. ${ }^{89}$

Moreover, the idea of regulatory arbitrage to gain advantage through use of subsidiaries domiciled in useful jurisdictions was beginning to take hold in the 1930s. Esso relocated its Baltic tanker fleet from the Free City of Danzig to Panama in the 1930 s to gain tax and regulatory advantages. ${ }^{90}$ Similarly, a Norwegian-English

2 Stephen Howarth \& Joost Jonker, A History of Royal Dutch Shell 31 (2007). See William Harvey Reeves, Displaced Corporations in Wartime-Switzerland's Answer, 14 BUS. LAW. 205, 212-13 (1958) (discussing problems of "refugee" corporations). The Germans "by hook or by crook" soon obtained "a majority of share capital" in Dutch businesses. L. DE JONG \& JOSEPH W.F. STOPPELMAN, THE LION RAMPANT: THE STORY OF HOLLAND'S RESISTANCE TO THE NAZIS 56 (1943). LOUIS DE JONG, THE NETHERLANDS AND NAZI GERMANY 36 (1990).

85. SLUYTERMAN, supra note 1 , at 113. The Dutch government-in-exile also took such steps as forbidding the transfer of Netherlands securities without government permission and forbidding the companies that relocated to pay dividends to those who could not prove ownership of shares prior to May 1940 or could not prove permission to acquire them after that date. Wagenmaker, supra note 71, at 9.

86. HOWARTH \& JONKER, supra note 84 , at 31 . Royal Dutch chose Curaçao in part because of a desire to keep the company's assets from being controlled by the British. Using a trust legally resident in Britain would have subjected assets to British law, while moving the statutory seat meant that "the assets remained subject to Dutch law .... and managers did not have to contend with outsiders who might have a different opinion about the interests of shareholders." Id.

87. See Christian Kirchner, Richard Painter \& Wulf Kaal, Regulatory Competition in EU Corporate Law after Inspire Art: Unbundling Delaware's Product for Europe, Univ. of Illinois Law \& Econ. Research Paper No. LE04-001 (2004), available at http:/papers.ssrn.com/sol3/papers.cfm?abstract_ id=617681 (explaining that " $[u] n t i l$ very recently, many countries in the EU applied the 'seat theory' under which a corporation is governed under the corporate law of its principal place of business or 'seat"'). European law is moving toward permitting competition for corporate charters more analogous to that allowed under U.S. law. See ERIN A. O'HARA \& LARRY E. RIBSTEIN, THE LAw MARKET 116-17 (2009).

88. Wet van 26 April 1940 STAATSBLAD VAN HET KONINKRIJK DER DEDERLANDEN [STB.] $1940 \mathrm{nr}$. 200; HOWARTH \& JONKER, supra note 84, at 27 (noting "special legislation enacted on 8 May 1940 to transfer the legal seat of companies to the overseas territories of the Kingdom of the Netherlands in case of an emergency"). The government-in-exile took other steps to secure Dutch assets outside of occupied territories in cooperation with Allied governments. See Anderson v. N.V. Transandine Handelmaatschappij, 43 N.E.2d 502, 504, 507 (N.Y. Ct. App. 1942) (demonstrating the New York court's and State Department's recognition of Dutch decrees preventing transfer of ownership of assets outside occupied territories).

89. Interview, Elias, United Trust Co., supra note 13; Interview, Paassen-Delsol, Paassen Delsol, supra note 71; Interview with Eric Andersen, Eclipse Consulting, LLC, Curaçao, Netherlands Antilles (May 19, 2008) [hereinafter Interview, Andersen, Eclipse Consulting, LLC].

90. Rodney Carlisle, Sovereignty for Sale: THE ORigins and Evolution of THE PANAMANIAN AND LiBERIAN Flags OF CONVENIENCE 48-52 (1981). A later company history also claimed the relocation was in anticipation of Nazi expansion, although this seems likely to be primarily a revisionist claim. Id. at $49-50$. 
whaling company moved its headquarters to France and its fleet to Panama's registry to avoid double taxation and labor regulations. ${ }^{91}$

As war began to appear increasingly likely in the late 1930s, Dutch companies made some preparations "to ensure the continuation of their international activities" in the event of war, preparing to move their statutory seats, executives, and managers, and to establish trusts and management companies." For example, "[a]s early as May 1939, the ... board [of Dutch multinational Ceteco] had issued a warrant entrusting the Curaçao managers with the overall control of the company's overseas business if and when the Netherlands should come to fall under enemy occupation." ${ }^{93}$ Following the invasion of the Netherlands, the government-in-exile took steps to validate the legal formalities related to these moves and to appoint new executives and directors where existing ones were trapped in occupied Holland. ${ }^{94}$ Keeping Dutch companies' international operations out of the hands of Germandominated entities back in the Netherlands also helped address the government-inexile's pressing financial problems, by making available important revenue sources. Although some of the early corporate moves were to Indonesia, ${ }^{96}$ the directors of the giant Dutch oil company Royal Dutch/Shell chose Curaçao because of the company's refinery operations there, moving both the statutory seat and a number of other international companies that formed part of the Royal Dutch/Shell group to the Antilles. $^{97}$

The convergence of war-related problems faced by Dutch multinationals and the Dutch law permitting the relocation of corporate statutory seats within the Kingdom presented an unprecedented opportunity that was quickly recognized and seized upon by a Dutch notary Anton Smeets. ${ }^{98}$ He persuaded a number of other Dutch multinationals to follow the lead of Royal Dutch/Shell and relocate their statutory seats to Curaçao. ${ }^{99}$ Smeets viewed Curaçao as the ideal site for relocated

91. Id. at 60 .

92. HOWARTH \& JONKER, supra note 84, at 29 (describing how Philips and Unilever set up overseas trusts by the summer of 1939 , and noting that "[m]anagers of the big Dutch multinationals held regular meetings to discuss joint political, legal, and financial problems and such an important subject as the legal preparations for war will have figured at those meetings."). Unfortunately, "[t]he history of Dutch business outside the Netherlands during the Second World War" remains "largely unexplored territory." SLUYTERMAN, supra note 1 , at 122.

93. JONKER \& SLUYTERMAN, supra note 2, at 253.

94. SLUYTERMAN, supra note 1, at 114; JONKER \& SLUYTERMAN, supra note 2, at 253.

95. See SLUYTERMAN, supra note 1 , at 114.

96. Shell, History of Shell in Indonesia, http:/www.shell.com/home/content2/id-en/about_shell/ who_we_are/history_of_shell_indonesia_0905.html (last visited Nov. 19, 2009).

97. HOWARTH \& JONKER, supra note 84 , at 29.

98. A notary is a Dutch independent legal professional appointed by the Crown for life who records legal agreements, either because the law requires it or at the parties' request. All notaries are law graduates and are experts in family law, succession law, corporate law and property law. The formal document drawn up by a notary, known as a notarial instrument, constitutes definite proof that the date and the parties' signatures to the relevant legal documents are correct. The notary retains the original notarial instrument and issues certified copies to each party. A specially endorsed copy, known as the execution copy, provides the same conclusive evidence of title as a court judgment. See DeNotaris, Royal Dutch Notarial Society (KNB) available at http://www.notaris.nl/page.asp?id=355 (last visited June 24, 2008). Lawyers have played roles similar to Smeets' in legal competition within the United States. See O'HARA \& RIBSTEIN, supra note 87, at 68-71 (an overview of the choice-of-court ability in the American legal system).

99. James O'Shea, Wall Street Helped Open 'Antilles Window', CHICAGo TRIB., Nov. 21, 1982, at S5. 
statutory seats because the island was relatively secure and an extremely important strategic asset for the Allies. The United States would not allow Curaçao's refinery, which turned Veneuzelan heavy crude into fuels critical for the war effort, to fall into Axis hands. ${ }^{100}$ By contrast, the location of the other major Dutch colonyIndonesia - put it squarely at risk of a Japanese invasion. ${ }^{101}$ A significant number of Dutch companies Smeets approached agreed to transfer their statutory seats to Curaçao. $^{102}$ Since these multinationals had directors outside of the Netherlands, they were able to authorize Smeets to act for them in Curaçao and the relocations were quickly accomplished, thus keeping their overseas assets outside of occupied territory and safe from German control..$^{103}$

100. Interview, Elias, United Trust Co., supra note 13; BLANSHARD, supra note 33, at 273 (describing defense arrangements during war with United States troops stationed on Curaçao within a month of Pearl Harbor); POOLE, supra note 40, at 128 (describing defense arrangements during war, with United States troops stationed on Curaçao within a month of Pearl Harbor); HISS, supra note 25, at 174 ("The rise of air power has doubled the significance of the West Indian islands not only as defenses for the Panama Canal but also as stepping stones to the South American continent, an importance which cannot be overemphasized."); E. Elias, The Hub of the Caribbean, in HOLland CaRRIES ON: THE NETHERLANDS WEST INDIES 38, 38 (1943) (quoting Dutch Minister for the Navy in 1942 that "Curaçao is of vital importance for keeping intact the communications across the Caribbean; it is highly important for defensive as well as offensive operations."). The Dutch Antilles generally were seen as "an essential link in the American defense periphery" after the U.S. entered the war in 1941:

The gold reserves of the Bank of Curaçao, about eight and a half million guilders, were shipped to the United States for safe-keeping. The Americans modernized the airports and made them feasible for bombers. Blackouts became mandatory and iron nets were lowered in St. Ann Bay and others to prevent the German U-boats, which seemed to be everywhere, from entering. Although there was never any overt danger of German occupation, many tankers sailing to and from the islands were torpedoed and sunk by the enemy. In February 1942, a refinery was even bombed. For some time in 1941 and 1942, these attacks came close to paralyzing the transport of oil. Oil, of course, was too important to allied warfare for any chances to be taken.... The refineries on both islands increased production, with the SHELL reaching 30,000 tons daily. Curaçao and Aruba provided the allied forces with 80 per cent of their high-octane fuel needs. It is no exaggeration to say that the gasoline refined on Curaçao and Aruba fed the war.

GoSLINGA, supra note 33, at 149. BLANSHARD, supra note 33, at 273 (noting U-boat attacks on Curaçao and terming submarine warfare in the Caribbean "very serious business."); Hiss, supra note 25 , at 169 (describing the torpedoing of tankers and submarine attempts to shell the refinery at Curaçao). See also OOSTINDIE, supra note 21, at 88-89 ("The Curaçaoan and Aruban oil refineries produced a significant amount of the fuel that was so vital for Allied forces ....").

101. Indonesia fell to the Japanese in early 1942 and was occupied through the end of the war. DE JONG, supra note 84, at 66. See also Huizinga, supra note 82, at 422-23; DE JONG \& STOPPELMAN, supra note 84 , at 321 (noting that the Dutch anticipated a Japanese attack); SLUYTERMAN, supra note 1, at 123 (business activities in Indonesia "came to an abrupt halt with Japan's lightning advance through Asia starting in December 1941."); DE JONG, supra note 84, at 59 (explaining that the Dutch cabinet had wanted to move the seat of government to Indonesia but Queen Wilhelmina refused to agree).

102. 1983 Tax Evasion Hearings, supra note 4, at 800 (statement of Harold Henriquez, Minister for the Netherlands Antilles Affairs, Government of the Netherlands Antilles).

103. HARTOG, supra note 19, at 317 (relocation of Shell). The Germans took steps to gain control of the Dutch economy, requiring all shares in foreign businesses to be registered: dollars, Swiss francs, and Swedish crowns had to be surrendered; interest and dividends due to Dutch holders of German shares were payable only through a special clearing house; loans to German borrowers had their interest rates lowered to 4\%; and other measures. DE JONG \& STOPPELMAN, supra note 84, at 54; Interview, Elias, United Trust Co., supra note 13; Interview with Hermann Behr, HBM Group, in Curaçao, Netherlands Antilles (May 19, 2008) [hereinafter Interview, Behr, HBM Group]; Interview, Paassen-Delsol, Paassen Delsol, supra note 71; Interview, Andersen, Eclipse Consulting, supra note 89 (some companies relocated to Sint Maarten as well); see also Hiss, supra note 24, at 408 ("many large Netherlands corporations have 
Smeets's idea had important consequences for the Antilles. One longtime Curaçao attorney termed Smeets "a visionary" for conceiving of Curaçao as an offshore center at a time when there was relatively little corporate infrastructure on the island. ${ }^{104}$ The transfer of the statutory seats of Dutch multinationals produced demand in Curaçao for corporate services and the small existing professional and legal infrastructure of accountants, lawyers, managers, and notaries began to develop to support the relocated companies. ${ }^{105}$ Smeets created CITCO, now one of the leading international offshore management companies, to provide such services in Curaçao..$^{106}$ In short, an emergency wartime legal maneuver set the stage for the development of the offshore sector in the post-war years by creating the human capital in Curaçao necessary to conduct business affairs and demonstrating to businesses worldwide that location of entities in Curaçao was both feasible and potentially beneficial.

A second important development during World War II was that the Antilles guilder became linked to the U.S. dollar. ${ }^{107}$ As a result, trade became increasingly oriented toward the United States rather than to the Netherlands. Even before the war, just under half of non-petroleum imports had come from the United States and only a fifth from the Netherlands. ${ }^{108}$ This increased flow of goods and services between the United States and the Antilles would help facilitate transactions between the two countries following the war. ${ }^{109}$

A final war-era development was a growing demand for autonomy in Curaçao, as well as in the other Dutch colonies. ${ }^{110}$ Recognizing this demand, the governmentin-exile in London announced plans for a post-war conference aimed at, as the Queen put it in a major address, "a commonwealth in which The Netherlands, Indonesia, Suriname, and Curaçao will participate, with complete self-reliance and freedom of contract for each part regarding its internal affairs but with the readiness to render mutual assistance." 111 What form this new post-war governance structure would take was unclear, but the Queen's speech suggested that considerable sovereignty would be shifted from the Netherlands to the non-European territories,

moved their offices to the West Indies")

104. Interview, Elias, United Trust Co., supra note 13.

105. Interview, Behr, HBM Group, supra note 103; Interview, Paassen-Delsol, Paassen Delsol, supra note 71 .

106. Interview, Paassen-Delsol, Paassen Delsol, supra note 71.

107. Prior to the war, notes denominated in Dutch guilders were issued by Curaçaoan banks. See NationMaster.com Netherlands Antilles Gulden, http:/www.nationmaster.com/encyclopedia/NetherlandsAntillean-gulden (last visited Oct. 11, 2009). After the war these were replaced by Antillean gulden which were not linked to the Dutch currency. Id.

108. Calculated from figures in HISS, supra note 25, app. XI, at 198.

109. OOSTINDIE, supra note 21, at 89; HARTOG, supra note 19, at 361 .

110. GASTMANN, supra note 39, at 22-23, 35-36 (discussing growth in demand for autonomy as a result of war); GOSLINGA, supra note 33, at 149 (discussing growth in demand for autonomy as a result of war); ANK KlOMP, POLITICS ON BONAIRE: AN ANTHROPOLOGICAL STUDY 68 (1986) ("The war years brought increased political awareness to the Antilles. The economic prosperity of that period, the necessarily increased autonomy of the region during the time when the Netherlands were occupied by Germany, and the universally heard cry for independence all fanned the desire for self-government on the islands.").

111. GASTMANN, supra note 39, at 25 (quoting Queen's Speech of Dec. 7, 1942); see also GoSLINGA, supra note 33, at 169 (discussing reaction to Queen's Speech); DE JONG, supra note 84, at 66-67 (noting that the Queen felt the speech "went too far"); OOSTINDIE \& KLINKERS, supra note 6, at 67 (discussing the debate between the Queen and her cabinet over content of speech). 
an idea that quickly took hold among island leaders. ${ }^{112}$ The important features of the constitutional framework that eventually emerged following the war remain essentially intact today. ${ }^{113}$ This framework figured importantly in both the development and limitation of Curaçao's offshore financial capabilities as discussed in the next section.

\section{Jurisdictional Foundations}

Although the Queen's 1942 speech called for a new constitutional framework for the Kingdom, it left the exact structure of that framework for later negotiations. Those negotiations took place within a narrower range than did contemporaneous discussions elsewhere in the Caribbean. On the one hand, there was broad agreement within the Dutch Caribbean territories that independence was not a serious option. ${ }^{114}$ Local leaders in the Dutch Caribbean believed that "the political assistance of Holland in obtaining financial aid and loans" would be crucial to postwar development and that "the economic stability of their homeland would be easier to preserve within the framework of a large nation than in a feeble federation of miniscule islands." 115 On the other hand, there also was agreement that the French solution of incorporating the Caribbean territories directly into the European nation was unacceptable. ${ }^{116}$ Thus both Dutch and Caribbean negotiators sought a middle ground between independence and incorporation.

112. OOSTINDIE \& KLINKERS, supra note 6, at 74 (stating that "autonomy was the ultimate goal" for Antillean politicians). Curaçao's leading politician, M. F. da Costa Gomez, argued that the Dutch needed to emulate the more flexible British approach to sovereignty, allowing it to be divided with the colonies, instead of maintaining their rigid approach. GASTMANN, supra note 39, at 35-36.

113. OOSTINDIE, supra note 21, at 90. Suriname became independent on November 25, 1975. Aruba formed a direct relationship with the Kingdom, as its separate colony, on January 1, 1986 with the understanding (later rescinded) that the island would achieve independence in 1996 . See Armando Lampe, The Recolonisation of Aruba, in ISLANDS AT THE CROSSROADS: POLITICS IN THE NONINDEPENDENT CARIBBEAN 106, 107-08 (Aaron Gamaliel Ramos \& Angel Israel Rivera eds., 2001) (discussing Aruba's status). The remaining five islands are in the midst of a transition that will ultimately eliminate the Antillean level of government, but the overall structure for the relationship between Aruba, Curaçao, Sint Maarten, and the Netherlands remains intact. Press Release, Government of the Netherlands, Curaçao and St Maarten to Have Country Status (Nov. 3, 2006), available at http://www.government.nl/News/Press_releases_and_news_items/2006/November/Cura_ao_and_St_Maart en_to_have_country_status.

114. The Dutch also left independence of the overseas territories off the table, with a government wartime pamphlet stating that the "all important principle" of constitutional development was "the principle of unity, the indivisibility of the Kingdom of the Netherlands, by which is not meant the Territory in Europe-what is generally called Holland-or any of the Overseas lands, but all these Territories together." J. H. Boas, Constitutional Development in HOLland CARRIES ON: THE NETHERLANDS WEST INDIES 47, 47 (1943).

115. GASTMANN, supra note 39, at 104; see also id. at 2-3 (noting that the Caribbean territories accepted the Kingdom structure rather than demanding complete independence, because in the early 1950 s their leaders believed "that their countries were too weak to stand alone" and because "the most important politically articulate groups in that period were not anti-Dutch" and included many of Dutch ancestry). Antillean Prime Minister Efrain Jonckheer told the United Nations in November 1955 that the Antilles preferred remaining in the Kingdom to independence "because this would ... not serve the interest, the advantage and security of the small conglomeration (of islands) in the situation in which the world at present finds itself ..." Id. at 102. Curaçao's representative in the government in exile in London during the war, and an important local political leader, Dr. M. F. da Costa Gomez was quoted in a wartime pamphlet as saying that "Curaçao is not a separate dominion (staatsdeel); it is the Netherlands in the tropics, waiting for Dutch initiative in favor of closer organic cooperation, in order to extend and broaden our unique community of nations." J.H. Boas, supra note 114, at 47.

116. OOSTINDIE \& KLINKERS, supra note 6, at 80-81; see generally Boise, supra note 14 (describing 
The constitutional structure ultimately proposed by the Dutch as a basis for association with its former colonies was developed with the objective of keeping Indonesia within the Kingdom, not with the well-being of the Caribbean territories in mind. ${ }^{17}$ Nonetheless, the Antilles could insist on being treated in the same way as Indonesia, which ultimately worked to Curaçao's advantage, as it led to the Antilles having formal equality with the Netherlands within the Kingdom. Given that the Netherlands had over seventy times the Antilles' combined population in the 1940s, while Indonesia's population was more than seven times larger than the Netherlands, ${ }^{118}$ this was a significant benefit for Curaçao. Thus, the Dutch focus on Indonesia resulted in a greater degree of autonomy for the Caribbean territories than they might otherwise have had.

Eventually, in 1949, the Netherlands was forced to accept Indonesia's complete independence. ${ }^{11}$ Thereafter, the Dutch government became intensely focused on restructuring the relationship between the Netherlands and the Caribbean territories, both the Antilles and Suriname. ${ }^{120}$ Although there were some difficulties over creating a tie-breaking mechanism for the Kingdom government, as well as over recognition of the right to secede (the Surinamese delegates wanted to explicitly recognize the right, while the Dutch preferred to leave it implicit in the document), ${ }^{121}$ the overall formal process of negotiations "went relatively smoothly." The six Dutch Caribbean islands were to be united into a single political unit called the Netherlands Antilles rather than Curaçao (as the islands collectively had been known

pursuit of that status by three of the islands currently in the Antilles).

117. OOSTINDIE, supra note 21, at 91; OOSTINDIE \& KLINKERS, supra note 6, at 62 (observing that Antilles were able to benefit "from the far-reaching concessions made in vain to the East Indies ..."); id. at 217 (stating that Charter "had in actual fact been designed during World War II with the specific purpose of winning over nationalist opposition in the major Dutch colony of Indonesia."). After a rocky start in 1948 that saw telegrams being sent by some of the Antillean delegates to the United Nations and Pan American Union appealing for "aid in their struggle to rid themselves of colonial oppression," the Caribbean and Dutch delegates agreed on a framework for discussions that would give each country the autonomy to create its own constitution and an overall Kingdom government. The Kingdom government would consist of the monarchy, a Kingdom cabinet in which Suriname and the Antilles would be represented with at least one member, a supreme court of the Kingdom to decide constitutional issues, a bicameral legislature combining the local legislatures, and a representative of the monarchy in the Caribbean countries with "the power of supervision." GASTMANN, supra note 39 , at 66-67; see also OOSTINDIE \& KLINKERS, supra note 6, at 76-88 (discussing conferences). Because the Dutch did not want to create a permanent structure for the Kingdom until they had resolved the situation in Indonesia, the Dutch government issued interim orders to amend the Staatsregelingen (constitutions) of the Caribbean territories to provide increased autonomy on an interim basis in early 1949. GASTMANN, supra note 39, at 69; GoslingA, supra note 33, at 170-71. These interim orders provided for local review of Dutch Parliamentary acts affecting the territories, limited Kingdom powers over internal matters, and created an independent judiciary. GASTMANN, supra note 39, at 70. They also dramatically democratized the islands' governments. The number of qualified voters rose from 5,000 to 65,000 with the introduction of universal suffrage in 1948-49. POOLE, supra note 40, at 177; see OOSTINDIE, supra note 21 , at 88 (discussing universal suffrage in the Antilles and Suriname in 1948).

118. HISS, supra note 25, at 182.

119. ADRIAN VICKERS, A HISTORY OF MODERN INDONESIA 112 (2005).

120. OOSTINDIE, supra note 21 , at $89-90$.

121. GASTMANN, supra note 39, at 88-89. Allowing revisions to the Charter to be accomplished easily and shifting the issue into the section dealing with amendments from the preamble resolved the secession issue. Id at a1-92.

122. OOSTINDIE, supra note 21 , at 90. 
previously). This unit would be one of three constituent parts of the larger Kingdom, along with Suriname and the Netherlands. ${ }^{123}$

This decision gave rise to what would become the most important issue for the Antilles; namely, how to structure a new pan-island government. ${ }^{124}$ The smaller islands feared that Curaçao would dominate the joint Dutch-Caribbean institutions because of its greater size. ${ }^{125}$ For example, Aruba insisted that the price for its participation in a six-island political unit be equal representation with Curaçao in joint institutions. ${ }^{126}$ Resolving this issue played a role in determining the overall structure of the Kingdom government, since creating separate federal structures would have presented significant challenges for both the Kingdom and the Antilles. The former would have been required to subsidize the expense of three separate layers of government, while the latter would have been required to produce from their populations enough qualified people to fill them. ${ }^{127}$

The dilemma was resolved by relying on Dutch institutions augmented with Caribbean members to serve as the Kingdom-level parliament and cabinet, thus limiting the number of new Kingdom institutions. The result was a Kingdom that was "a federative structure with confederative traits." 128 The "principal Kingdom institutions" were to be the monarchy (represented by a governor in Caribbean territories), the Council of State, the Council of Ministers (the Cabinet), the States General (Parliament), and the High Court of Justice of the Netherlands. ${ }^{129}$ Although the Kingdom would be treated as one nation under international law, it would allow

123. GASTMANN, supra note 39, at 66-68.

124. Id. at 73-74. See also GosLingA, supra note 33, at 174 ("[T]he political problematic is decided by island individualism. There are island interests and an insular mentality.").

125. GASTMANN, supra note 39, at 104 ("In the Antilles the smaller islands wanted countervailing power to prevent Curaçao from dominating them both politically and economically.").

126. Id. at 57. An example of the disputes was the police controversy over whether new policemen for Aruba would be recruited in Holland or Curaçao when there were no local applicants. Id. at 56-57.

The central concept of the Island regulations, adopted by the Dutch Government in 1951 after the proposals of the Staten had been carefully studied, was that each of the four island areas created by the regulation, namely, Curaçao, Aruba, Bonaire, and the Windwards [Sint Maarten, Sint Eustatius, and Saba], should have complete freedom to govern themselves and make their own laws. Only a limited number of matters explicitly stated in the island regulations was left to the authority of the Central Government in Willemstad [on Curaçao]. These matters concerned immigration, justice, currency, post and telegraph, and control over the police force of the Antilles.

Id. at 74. The result was "an advantage" for the other islands over Curaçao despite Curaçao's larger size. GOSLINGA, supra note 33, at 172 .

127. The manpower issue was a serious one. One local Curaçao newspaper opined that:

For the introduction of the new constitutional structure ... already the former Governor had calculated that forty persons were needed to occupy the key positions and the maximum number of people who are available are not even five....

GASTMANN, supra note 39, at 59 (quoting Vrome Wensen voor de Nederlandse Antillen, AMIGOE (Curaçao), June 21, 1949). Although in the initial 1948 draft of the Kingdom Charter there had been a separate Kingdom government, the 1952 draft instead "let Dutch institutions function as Kingdom institutions," augmented with representatives of Suriname and the Antilles. Both Dutch and Caribbean delegates accepted this compromise because the expense of a new level of government seemed unnecessary in light of the Kingdom's limited responsibilities. Id. at 87.

128. GASTMANN, supra note 39 , at 4.

129. Id. at 109. 
each of its constituent parts virtually complete autonomy over all but a few matters. ${ }^{130}$ Crucially, each jurisdiction within the Kingdom had almost complete legal autonomy on fiscal matters, ${ }^{131}$ which allowed the Antilles government to later create its innovative offshore tax regime.

The "mixture of moral and largely pragmatic considerations" in designing the Kingdom, however, left a "democratic deficit" regarding the Caribbean territories as the Kingdom ministerial council was not responsible to any Kingdom legislative body and so was dominated by the Dutch. ${ }^{132}$ The Kingdom ministerial council made the government more responsive to Dutch politics than to the non-European polities' needs. ${ }^{133}$ While the overall constitutional result was what one analyst has termed "a remarkable document," it was one with a "far from watertight construction" since it rested on a "remarkable fiction, namely the fiction of the complete equality of the de facto unequal partners in the Kingdom." 134 Crucially, while the Caribbean jurisdictions gained the autonomy they sought, they did not get "too much" autonomy, which likely would have been problematic for the growth of the offshore sector. Investors would need assurance that their investments were safe, and Antilles' maintenance of close ties to the Dutch provided that assurance. ${ }^{135}$ But this reassurance came at a price: foreign affairs, defense, Dutch nationality, and "the guarantee of fundamental human rights and freedoms, the rule of law and good governance" were specifically made Kingdom responsibilities. ${ }^{136}$

130. See id. at 2.

131. As one historian noted:

The countries are completely autonomous in formulating their internal economic policy and as far as their own finances are concerned the Caribbean States are quite independent of the Netherlands. They issue their own currency and determine its value, without interference from The Hague. There is no Kingdom Treasury .... [T] he lack of a common treasury and the fact that the Caribbean countries regulate their own currency give them a financial independence which is rare in federal states of today.

Id. at 115; ANDIC \& ANDIC, supra note 25, at 171 ("Politically, the Netherlands Antilles have enjoyed ... virtual autonomy in domestic affairs since 7 February $1951 \ldots$..."). The result satisfied the United Nations, which exempted the Netherlands from further reporting on the process of decolonization after December 1955. Rita Giacalone, The Political Status of Curaçao at the End of the Twentieth Century, in ISLANDS AT THE CRossroads: Politics in THE NON-INDEPENDENT CaribBean 95 (Aaron Gamaliel Ramos \& Angel Israel Rivera eds., 2001).

132. OOSTINDIE \& KLINKERS, supra note 6, at 85-86.

133. Id. ("Care had been taken to ensure that almost complete power over the affairs of the Kingdom remained on the European side of the Kingdom ....").

134. OOSTINDIE, supra note 21, at 90-91. The Charter was well received in the Western European and American press. The New York Times called the new Charter "one of the most interesting developments in the whole story of the modification of former "colonial' structures." Id. (quoting Editorial, New Caribbean Autonomy, N.Y. TIMES, Dec. 16, 1954, at 36).

135. One area that investors are particularly concerned about with respect to offshore jurisdictions is the stability of the court system that will adjudicate their disputes. In the Netherlands Antilles, judges were appointed by the Queen and had life tenure (albeit with retirement at age 60). This gave the judges a substantial degree of independence from local politics. GOV'T. INFO. SERV. (Neth. Antilles), THE NETHERLANDS ANTILLES 30 (1961). In 1961, the Antilles adopted a statute making the Netherlands High Court the "court of cassation" for Antillean courts under Article 23 of the Charter. GASTMANN, supra note 39, at 114 (noting that in civil law jurisdictions, this is the court of final appeal). This remains an important selling point for the Antilles offshore sector.

136. OOSTINDIE, supra note 21 , at 90 (quoting Charter art. 43 , citing art. 3 ). 
The Dutch cabinet, augmented by Caribbean ministers, served as the Kingdom Cabinet while the Dutch Parliament, augmented by Caribbean members, served as the Kingdom Parliament. ${ }^{137}$ Of particular significance for the future of the Netherlands Antilles' offshore financial center aspirations was the power the Dutch retained over foreign affairs. ${ }^{138}$ This would contribute to an overall lack of flexibility in responding to developments in the offshore world because Curaçao was left dependent on the Dutch-dominated Kingdom government for approval of tax treaties. The tax treaties were a subject where Dutch and Antillean interests did not always coincide. Moreover, the Dutch retained other important measures of control, continuing, for example, to appoint Dutch rather than Antillean governors of the Antilles for years. ${ }^{139}$ As one assessment concluded, the Dutch maintained considerable control because "The Hague stuck to a policy of pulling the strings."

Why did the Netherlands agree to de jure equality with the Antilles (and Suriname) within the Kingdom? There were no major economic benefits for the Netherlands in maintaining a relationship with the Antilles, ${ }^{141}$ although some particular Dutch interests did benefit from continuing ties with the islands. ${ }^{142}$ The scholarly consensus is that the Dutch agreed to the Charter based on both economic and charitable motivations. ${ }^{143}$ The cost to the Netherlands of de jure equality was minimal given de facto Dutch control of the Kingdom institutions. Further reducing the cost to the Dutch was their expectation that the Charter structure would not prove long-lived and would eventually be followed by "a looser union." 144 Nonetheless, the compromise was successful in addressing the most pressing needs of its constituents - "three countries that had rather little to do with each other" 145 -as the "Charter worked more or less smoothly" throughout the 1950 s and $1960 \mathrm{~s} .{ }^{146}$

137. GASTMANN, supra note 39 , at 66-67.

138. See id. at 114 (citing Charter art. 3) (discussing the requirement of Kingdom involvement in treaties).

139. OOSTINDIE \& KLINKERS, supra note 6, at 73 ("For example, no consideration was given to questions such as the appointment of a native ... Antillean Governor.").

140. Id.; see also Giacalone, supra note 131, at 101 (observing that the Dutch channeling of aid through Antilles government "expanded the Dutch influence within the island system").

141. GASTMANN, supra note 39, at 4; OOSTINDIE \& KLINKERS, supra note 6, at 10 (noting that the Antilles "had little economic significance to the metropolis, and this would remain the case"); OOSTINDIE, supra note 21, at 21 ("The balance sheet of Dutch colonialism in 'the West' is utterly delusional. A world that was created to make profits generated mainly ever-growing losses.").

142. GASTMANN, supra note 39 , at 3-4.

143. Id. ("[T]here existed in Holland a feeling, expressed by church groups and humanitarian movements that the well-being of the people [in the colonies] should be the primary concern of the colonial administration. Many of the civil servants had always considered that their primary duty was towards the colonial people. These men had more influence in shaping policy than [those who argued it was all due to economic interests] realized."); OOSTINDIE \& KLINKERS, supra note 6, at 74 (arguing that "[e]conomic interest is no credible explanation" for Dutch willingness to continue association with the Caribbean territories but not finding any other strong explanation beyond "a feeling that a mission needed to be accomplished" and that the territories needed to be protected from territorial claims by Venezuela and Brazil).

144. GASTMANN, supra note 39, at 4. These doubts continue with the discussion of the Charter in Professor Oostindie's recent history of the Dutch Caribbean entitled "Pit Stop or Finish?". See OOSTINDIE, supra note 21 , at 91 (questioning whether the Charter will survive).

145. OOSTINDIE \& KLINKERS, supra note 6 , at 218.

146. OOSTINDIE, supra note 21 , at 92 . There was some effort by the Caribbean territories to increase their role in Kingdom affairs, but the Dutch "would not make any real concessions" at a 1961 roundtable on the issue, with The Hague insisting that it retain control of Kingdom foreign affairs. OOSTINDIE \& KLINKERS, supra note 6, at 90. 
Importantly, its concept of formal equality created jurisdictional space for the development of an offshore financial sector in the Netherlands Antilles.

\title{
II. THE ARC OF ANTILLEAN FINANCIAL INTERMEDIATION
}

We now turn to how this new autonomy, the wartime experience with the relocated multinationals, and the island's history combined to create the opportunity for the development of an offshore financial center.

\section{A. The Economic Need to Create an Offshore Sector}

At the close of the war, Curaçao had what was likely the highest standard of living among Caribbean colonies, due to the refinery's provision of regular, well-paid employment for large numbers of Curaçaoans. ${ }^{147}$ This refinery-based prosperity continued for a decade after the war, but after 1958 the refinery proved to be an unstable foundation for economic prosperity. The islands faced "great economic difficulties" as Venezuela began to insist on greater investment in its own refining capacity in exchange for access to its oil. ${ }^{148}$ By limiting oil imports under the Mandatory Oil Import Program (MOIP), the United States caused the refineries in the Antilles to begin to face demand constraints. ${ }^{149}$ Far from the prosperity of the immediate post-war period, a visiting Dutch Parliamentary commission in 1959 found "great social, economic, and political neglect" in the Antilles. ${ }^{150}$ Despite these problems, however, GDP per capita in the Antilles was US $\$ 11,495$ in 1960, the second highest in the Caribbean. ${ }^{151}$

The Antilles' economic problems worsened during the 1960s. Unemployment in the islands rose from fourteen percent of the labor force in 1961 to twenty-four to twenty-seven percent of the labor force in $1966,{ }^{152}$ remaining above twenty percent

147. BlANSHARD, supra note 33, at 277. See also POOLE, supra note 40, at 179 (1951 book concluding that "[i]n the final analysis ... the future economic prosperity of the islands depends almost entirely upon the petroleum industry").

148. OOSTINDIE \& KLINKERS, supra note 6, at 89-90.

\begin{abstract}
After the fall of [Venezuelan president] Marcos Pérez Jiménez in [1958], the Venezuelan government embarked on an extensive program of refining its own oil, although scrupulously observing existing contracts with SHELL and LAGO. Yet, a tacit understanding was reached with these companies not to expand their refineries on the islands. Concomitantly, both SHELL on Curaçao and LAGO on Aruba initiated a process of automation which, for the first time since the Great Depression of the early thirties, caused a downward trend in the labor force.
\end{abstract}

GoslingA, supra note 33, at 175. See also GASTMANN, supra note 39, at 140 (describing how the mechanization of oil industry caused economic dislocations); HOWARTH \& JONKER, supra note 84, at 41 (noting agreement by Royal Dutch/Shell to "limit the processing capacity of Curaçao to $200,000 \mathrm{~b} / \mathrm{d}$ or 10.4 million tons a year" in response to Venezuelan demands to increase refining domestically).

149. ANDIC \& ANDIC, supra note 25, at 177. See Andrew P. Morriss \& Nathaniel Stewart, Market Fragmenting Regulation: Why Gasoline Costs So Much (and Why It's Going to Cost Even More), 72 BROOK. L. REV. 939, 991-1001 (2007) (discussing the history of the MOIP).

150. GosLINGA, supra note 33 , at 152 .

151. OOSTINDIE \& KLINKERS, supra note 6, at 154.

152. ANDIC \& ANDIC, supra note 25, at 173. 
for the balance of the decade. ${ }^{153}$ Per capita GDP fell fifteen percent in real terms between 1957 and $1965 .{ }^{154}$ Exacerbating the economic problems, just as the refinery workforce was falling dramatically from 13,000 laborers in 1952 to less than 4,000 in 1967 , the island's population was rapidly increasing, growing by almost thirty-five percent in the same period. ${ }^{155}$ Moreover, the close relationship between the rest of the industrial economy and the refining sector meant that as the latter declined so did the former. ${ }^{156}$ This combination pressured the Antilles government to find economic development projects and, in response, it "made a serious attempt to create a favorable climate for investment," focusing on tourism, ${ }^{157}$ the creation of temporary monopolies to be offered as a lure for investment, and appeals to The Hague for development aid. ${ }^{158}$ Despite some limited successes, a review in 1975 by the central bank concluded that 1969-74 had been a period of falling prosperity, largely due to declining employment at the refinery. ${ }^{159}$

153. GosLiNGA, supra note 33, at 177 (noting that unemployment was substantial in the 1960s, ranging from 18 percent of the labor force of 55,000 in 1964 to 20 to 25 percent of the labor force of 73,000 in 1970).

154. ANDIC \& ANDIC, supra note 25, at 174.

155. GOSLINGA, supra note 33, at 175. Although the refinery workforce on Curaçao was in decline, the Royal Dutch-Shell Group remained at the time "the second largest oil organization in the free world, operating in more than ninety countries through 500 associated companies." Profit Is Raised for Royal Dutch, N.Y. TIMES, March 3, 1962, at 25.

156. ANDIC \& ANDIC, supra note 25, at 177.

157. GosLingA, supra note 33 , at 175 . Initial post-war assessments suggested that Curaçao's appeal to tourists was limited, with one concluding that while "Curaçao is a beautiful sight in the sun with its clean tinted buildings ... few tourists would care to spend more than a day there." BLANSHARD, supra note 33 , at 71 . But in the early 1960 s, Curaçao experienced a small boom in tourism as cruise ships drawn by the available cheap fuel arrived in increasing numbers, a luxury hotel was built, and a growing number of U.S. tourists visited. Early cruises stopped at Curaçao for the cheap fuel available at the refinery. HARTOG, supra note 19, at 325. The scale was still small enough that construction of a 124-room hotel merited significant attention in a government brochure on the economy in 1961. GOV'T. INFO. SERV. (Neth. Antilles), supra note 135 , at 39.

158. GoslingA, supra note 33, at 175. The incentives for new industry were not particularly successful, in part because the domestic market was too small to support additional industry and in part because of "lack of coordination between the levels of government." ANDIC \& ANDIC, supra note 25, at 179. The appeals for aid were successful in attracting funds from Europe, particularly once the Antilles' participation in the European Common Market (beginning in 1964) made the island eligible for additional development aid. GosLiNGA, supra note 33, at 176-77. The Antilles' associate membership was two years behind Suriname's, largely because of disputes over oil exports from Curaçao's refinery, which were settled by an agreement to allow the E.E.C. to impose a tariff on the oil products "in case of market disturbances." ANDIC \& ANDIC, supra note 25, at 172. The Kingdom adopted a 114 million guilder (US\$275.2 million) "Urgency Plan" for Curaçao and Aruba in the 1960s to support construction of roads, airport improvements, water plants, and other infrastructure, and the Netherlands picked up the tab for two thirds of the development projects. GosLINGA, supra note 33, at 177; ANDIC \& ANDIC, supra note 25, at 172. Unfortunately, while the aid did improve living standards in the Caribbean territories, it did not "[lead] to noticeable developments in terms of economic viability and self-sufficiency...." OOSTINDIE, supra note 21, at 94. Efforts to promote foreign investment suffered a blow when the 1964 revision of the tax treaty between the Netherlands and the United States "eliminated most of the incentives offered to the investor." GosLINGA, supra note 33, at 176; see infra note 265 and accompanying text. Nonetheless, overall capital investment continued to increase, although not by enough to provide a sufficient substitute for the decline in the refinery's labor force.

For the currency conversions, we converted a Dutch guilder in 1965 to 2.15 guilders in 2006 and then converted it to U.S. dollars as of Oct. 11, 2008 (calculated by the currency calculator of the International Institute of Social History, http://www.iisg.nl/hpw/calculate.php (last visited Nov. 13, 2009)). In 20061 guilder was worth roughly US\$1.28. See OANDA.com, supra note 59.

159. Bank VAN DE Nederlandse ANTIllen, RePORT ON THE PERIOD 1969/1974 5-8 (1975); GoSLINGA, supra note 33, at 175. Similarly, a 1968 analysis of the Antilles' economy concluded that "the 
The island's economic problems played a major role in riots in the capital city of Willemstad on May 30, 1969. The city "burst into flames" and the intervention of Dutch troops was required to restore order. ${ }^{160}$ The riots damaged the Netherlands' international reputation, as they became "[f]ront-page news in the international press ... with photographs of military patrols on the streets of Willemstad," publicity which significantly "undermined the progressive image the Netherlands liked to present of itself." 161 The May riots led to the Dutch government "quite suddenly mov[ing] to the active pursuit of independence for its Caribbean territories." 162 The Minister for Surinamese and Antillean Affairs made clear that the Dutch viewed the two countries as an economic liability, speaking of the "millions of guilders" the Netherlands put into them annually. ${ }^{163}$ Indeed, the Dutch spent 900 million guilders (more than US\$2 billion ${ }^{164}$ ) on aid to the Antilles between 1960 and 1975. ${ }^{165}$ The Dutch viewed the mix of their responsibility to maintain order and their concomitant lack of ability to affect the quality of government in the Caribbean as problematic. ${ }^{166}$ As a result the Dutch began to take a more active role in the islands' governance and replacing the governor (who had been nominated by the island government) with their own choice. In 1971 they announced that a substantial majority in the Dutch parliament favored transfer of sovereignty, roiling island politics. ${ }^{167}$ Political instability increased after 1969 , with no Antillean government lasting more than two years. Antillean politics was then based on coalitions of insular parties rather than multi-island support for a party. ${ }^{168}$ The Dutch at least temporarily abandoned their efforts to encourage Antillean independence as Suriname's problematic post-

levels of consumption and investment achieved by the Netherlands Antilles in the past have been made possible only because of external assistance mainly from Holland and private sector investments from the United States, and that, given the prevailing unemployment and other circumstances of the economy, they will continue to be possible with continued external assistance ..." ANDIC \& ANDIC, supra note 25, at 211-12.

160. See OOSTINDIE, supra note 21 , at 93.

161. Id. at 95 . As Oostindie and Klinkers summarize the impact of on the Dutch image:

Images of Dutch Marines patrolling the smouldering ruins of Willemstad, machine guns at the ready, had been transmitted worldwide. With little understanding of the Kingdom relations and the nature of the Charter, the world inevitably witnessed colonial intervention. In hindsight this concern needs to be understood above all as a typical Dutch overestimation of the interest existing abroad for the way the Netherlands acted within its own sphere of influence. Yet this concern would be instrumental in the new Dutch approach to the Kingdom relations

OOSTINDIE \& KLINKERS, supra note 6, at 99.

162. OOSTINDIE \& KLINKERS, supra note 6, at 90-91; see also Giacalone, supra note 131, at 96 ("[A]s a consequence of the political disturbances on May 30,1969, the question of political status became a crucial theme of discussion ....").

163. OOSTINDIE \& KLINKERS, supra note 6, at 116.

164. Calculated using the 1968 mid-point values. International Institute of Social History, supra note 59 (for conversion of 900 million 1968 guilders into present value); Coinmill.com-The Currency Converter, http://coinmill.com/ANG_USD.html\#ANG (last visited Nov. 13, 2009) (for conversion into U.S. dollars).

165. OOSTINDIE \& KLINKERS, supra note 6, at 159.

166. Id. at 98 .

167. Id. at 100-01; see also id. at 102 (recalling that the Dutch government that took office in 1973 announced a policy of opening talks on a time table for independence for the Caribbean territories).

168. Giacalone, supra note 131 , at 100-01. 
independence experience diminished Dutch enthusiasm for shedding its remaining overseas territories. ${ }^{169}$

A second impact of the riots was a large increase in social spending in the early $1970 s^{170}$ Some of this spending was financed by aid from the Netherlands, but the growth in revenue from the growing offshore sector also was a significant source of funds. ${ }^{171}$ On the islands, the riots were a harsh reminder "of the broad divide separating the elite and working classes, a gulf that was as much socio-economic as it was racial and cultural." 172 Today, May 1969 is "routinely interpreted as the watershed in post-Charter Curaçao," marking the moment when politics shifted from "a small, predominantly non-black local elite" to an arena dominated by "local black leaders." It does not appear to have produced a parallel change "in the economy and in private relations - in this respect too, the Curaçao experience parallels the unfinished emancipation elsewhere in the Caribbean." 174 And notably, it did not affect the growing offshore financial sector, a testament to the credibility of the Dutch guarantee of the rule of law and stability. ${ }^{175}$

In short, a gradual but significant reduction in employment at the Curaçao refinery coupled with a growing population produced an overall decline in economic conditions in the Antilles in the two decades following World War II. The islands needed an industry that could provide government revenue, create jobs, and usher in greater opportunity for residents. Although tourism initially appeared to be a promising option, it ultimately failed to achieve the scale necessary to generate economic prosperity for Curaçao, growing most rapidly elsewhere in the Antilles. Thus, conditions were ripe for the development and growth of the offshore financial services sector, the early stages of which are discussed in the following section.

\section{B. The Beginnings of Offshore Activity}

Following World War II, many of the companies that had relocated their statutory seats to Curaçao as a result of the German occupation moved them back to the Netherlands. ${ }^{176}$ Without the German occupation of Holland, the island needed another reason for companies to maintain their formal connection to Curaçao. With few resources, Anton Smeets, the notary who pioneered the World War II statutory seat relocations, embarked on a campaign to both persuade the Antilles government to create a climate that could draw business and to promote Curaçao to the international business community. ${ }^{177}$ At this same time, multinationals-particularly

169. KLOMP, supra note 110 , at 75 ; see also Giacalone, supra note 131 , at 97 (describing course of discussions over status through the 1970s and early 1980s).

170. BANK VAN DE NEDERLANDSE ANTILLEN, supra note 159, at 6.

171. GOSLINGA, supra note 33, at 175-76; BANK VAN DE NEDERLANDSE ANTILLEN, supra note 159, at 6 (the "rapid increase in the number off-shore companies which had a favourable effect on the tax proceeds"); id. at 8-9 (describing how, in 1973-74, "continued growth of tax income from off-shore companies" and more aid made it possible for improvements in government budget, despite economic troubles and worsening employment statistics).

172. OOSTINDIE, supra note 21 , at 93 .

173. Id. at 126-27.

174. Id.

175. LANGER, supra note 9, at 188 (noting that the riots "had relatively little effect on the use of the Netherlands Antilles as a base for offshore operations").

176. Interview, Elias, United Trust Co., supra note 13.

177. Id. 
oil companies-began actively seeking opportunities to arbitrage among legal regimes with respect to mobile assets, creating potential demand. ${ }^{178}$

Smeets's greatest accomplishment during the decade following the war was convincing the Antilles to adopt a tax regime that was particularly favorable to businesses having their statutory seats in the islands but doing business elsewhere. ${ }^{179}$ Thus, the Antilles became the first jurisdiction to set up such a regime-now known as a "ring-fenced tax regime" - in 1954. ${ }^{180}$ Under this regime, a Netherlands Antilles company earning only passive income and having neither its beneficial ownership nor any business activity within the Antilles would be exempt from Netherlands Antilles taxation on all but ten percent of its profits. ${ }^{181}$ Such an entity could secure an effective tax rate of between 2.4 and three percent. ${ }^{182}$ Moreover, at a time when exchange controls were common, the Antilles did not impose significant barriers to the transfer of currency by offshore companies. ${ }^{183}$

The early results of the Antilles' new tax regime were largely positive, as over 300 holding and investment companies were incorporated in the Netherlands Antilles between 1953 and $1960 .^{184}$ Taxable profits from companies participating in the Antilles' ring-fenced tax regime were estimated at between NAf 67 and NAf 121 million in the mid-1950s (US\$35.6 million to US\$64.1 million ${ }^{185}$ ), making the regime a valuable, although fluctuating, resource. ${ }^{186}$ By the end of the $1960 \mathrm{~s}$, the offshore sector was firmly established as an important part of the Antilles' economy.

Notwithstanding the initial success of the Antilles offshore sector, there were some bumps in the road. At that time, Curaçao had a fairly primitive physical infrastructure that one long-time Curaçao attorney characterized as "three donkeys and six dinosaurs." 187 Nonetheless, as a result of the events surrounding World War II, the island possessed a sufficient professional services infrastructure composed of

178. See CARLISLE, supra note 90, at 110 ("The war had exposed hundreds of business and government leaders to the system of business convenience under Panamanian registry, which had been tried out on a small scale in the 1930s. In the period from 1946 to 1948 that alternative appealed widely as American tanker owners utilized the flag to build a competitive position in the market.").

179. GOV'T. INFO. SERV. (Neth. Antilles), supra note 135, at 49.

180. Interview, Behr, HBM Group, supra note 103.

181. Id. The company also could expect to receive some leniency in tax rulings that would further reduce its tax liabilities. Id. The ten-percent rule was a substitute for a foreign tax credit. 1983 Tax Evasion Hearings, supra note 4, at 802 (statement of Harold Henriquez, Minister for the Netherlands Antilles Affairs, Government of the Netherlands Antilles).

182. The applicable tax rate was 2.4 percent on the first one million of a company's income, and 3 percent on the balance. Interview, Elias, United Trust Co., supra note 13; Interview, Paassen-Delsol, Paassen Delsol, supra note 71. See also LANGER, supra note 9, at 193 (describing reduced tax rates available for selected types of companies). Similarly, banks were taxed at an effective rate of 3 percent by taxing only 10 percent of their income at the nominal rate of 30 percent. Interview, Paassen-Delsol, Paassen Delsol, supra note 71.

183. BANK VAN DE NEDERLANDSE ANTILLEN, supra note 159, at 43.

184. GOV'T. INFO. SERV. (Neth. Antilles), supra note 135, at 49. See also Interview, Paassen-Delsol, Paassen Delsol, supra note 71.

185. In nominal dollars. The Antillean guilder was pegged to the U.S. dollar at a rate of 1.88585 to the dollar until 1971, when it was adjusted to 1.79:1. See Int'l. Monetary Fund [IMF], Kingdom of the Netherlands-Netherlands Antilles: 2003 Article IV Consultation-Staff Report; Public Information Notice on the Executive Board Discussion, app. I, IMF Country Report No. 03/160, June (2003) Appendix I, at 32, available at $\mathrm{http}: / / \mathrm{www}$.imf.org/external/pubs/ft/scr/2003/cr03160.pdf.

186. ANDIC \& ANDIC, supra note 25, at 189.

187. Interview, Elias, United Trust Co., supra note 13. 
accountants, lawyers, notaries, and other professionals that was now prepared to assist foreign companies in taking advantage of the new tax regime. Evidence of the growing interest in financial structures utilizing the Antilles' tax regime can be seen in period literature. For example, a 1960 translation of the Netherlands' corporation law included notations of differences between Antillean and Dutch law, and its introduction observed that the translation was undertaken in response to "requests for information about Netherlands Antilles corporation law from several American interested parties." 188 And a government brochure promised potential investors in Antilles companies that

The Netherlands Antillean Government ... accords the greatest possible freedom to business and industry, shuns any oppressive controls and recognizes the vital importance of free enterprise to the country's prosperity. Thoughts about nationalization or any other alienation of property rights are unknown in the Netherlands Antilles. ${ }^{189}$

However, the handicap of doing business as a civil law jurisdiction using Dutch as its official language when dealing with a common law, English-speaking economy like the United States is apparent in this literature. For example, a pamphlet on Dutch corporation law translated into English highlighted the problem, noting that it used "American legal expressions" where possible, and attempted to explain "principles of which a few are typically different from common law conceptions" to "those not well versed in Roman law." "With at least three English translations in use, which "differ somewhat from one another," a 1975 survey concluded that it was "wise" to compare all three translations "in order to frame meaningful questions to local counsel and to comprehend his replies." Moreover, articles of incorporation had to be filed in Dutch, ${ }^{192}$ an additional expense and barrier to client comfort. But by being among the first of the offshore jurisdictions (only the Bahamas was offering real competition in the Caribbean in the 1960 s and early $1970 \mathrm{~s}^{193}$ ), Curaçao was able to overcome these handicaps.

\section{C. "Like Finding Gold" "19*}

The 1950 s and 1960 s were a period of radical transition in the world economy. The post-war Bretton Woods currency system was breaking down in the late 1960s, and ultimately collapsed in $1972 .{ }^{195}$ As a result, exchange controls and other barriers

188. DutCh CORPORATION LAw 3 (S.W. Van Der Meer trans., 1960).

189. GOV'T INFO. SERV. (Neth. Antilles), supra note 135, at 48.

190. DUTCH CORPORATION LAW, supra note 188 , at 3.

191. LANGER, supra note 9, at 125-26 (noting that two of the three were "literal" translations while the third was "less literal" and "makes substantial use of footnotes to explain how the law works" although it was out of date and "probably out of print"). In addition, the text of the tax treaty itself was difficult to find into the 1970s, with Langer noting that the treaty "does not appear as a separate treaty in any of the U.S. tax treaty services." Id. at 122.

192. Id. at 190 .

193. Andrew P. Morriss \& Craig M. Boise, Creating Cayman: The Making of an Offshore Financial Center 22-25 (unpublished manuscript, on file with author) (describing the great successes of the offshore banking industry in the Bahamas).

194. Interview, Elias, United Trust Co., supra note 13.

195. BARRY EICHENGREEN, GLOBALIZING CAPITAL: A History OF THE INTERNATIONAL MONETARY SYSTEM 123-34 (1996). 
to the movement of capital slowly eroded and capital markets became more accessible. ${ }^{196}$ In the late 1960 s, as banks around the world began to accept deposits denominated in foreign currencies, the so-called "Eurocurrency" market was born. The Eurodollar market grew substantially as the dollars that paid for the increasing volume of U.S. imports came to rest outside the United States. ${ }^{197}$ The soaring price of oil in the early 1970s, in particular, created massive pools of "petrodollars" in oilexporting countries that could be tapped for investment. ${ }^{198}$

As the Eurodollar market grew, U.S. firms sought to access it to fund domestic investment. ${ }^{199}$ They were aided in their pursuit by persistent U.S. balance of payments deficits in the 1960s that ultimately led the government to enact a series of measures designed to encourage U.S. multinationals to borrow outside the United States. ${ }^{200}$ Even after the balance of payments issues of the 1960s disappeared, the Eurodollar market remained attractive to U.S. businesses. For a variety of reasons including costly U.S. banking regulations-Eurodollars could be borrowed at interest rates that were lower than domestic U.S. interest rates. ${ }^{201}$ In addition, U.S. banks

196. Id. at 191 ("[A]s international transactions were liberalized, it became impossible to keep domestic markets tightly regulated. Once financial markets joined the list of those undergoing decontrol, new channels were opened through which capital might flow, and the feasibility of controlling international capital movements diminished accordingly.").

197. See Oscar L. Altman, Euro-Dollars, in READINGS IN THE EURO-DOLlaR 1, 2 (Eric B. Chalmers ed., 1969) ("[T]he Euro-dollar market is now one of the world's largest markets for short-term fundsmostly dollars. It is an international market, and it is one of the freest, most competitive, and most flexible capital markets that exists anywhere."); The Eurocurrency Market Control Act of 1979: Hearings Before the Subcomm. on Domestic Monetary Policy and the Subcomm. on International Trade, Investment and Monetary Policy of the Comm. on Banking, Finance and Urban Affairs, 96th Cong., 1st Sess. (1979) (discussing how the Eurodollar market grew from $\$ 110$ billion to $\$ 695$ billion between 1970 and 1977).

198. See Frederick G. Fisher III, ThE Eurodollar Bond Market 17-19 (Euromoney Publications Ltd. 1979) (describing the role of "recycling" petrodollars back into the U.S. economy from oil states).

199. 1983 Tax Evasion Hearings, supra note 4, at 168 (statement of Robert Butcher, Vice President, Citicorp) ("No large borrower of funds in the world today can ignore the Eurobond market, for it is a sizeable source of funds, and it is growing more rapidly than the U.S. corporate bond market."); 1983 Tax Evasion Hearings, supra note 4, at 587 (Taxecon Associates, Consequences of Imposing the U.S. 30 Percent Withholding Tax on Interest Paid to or by Netherlands Antilles Finance Subsidiaries of U.S. Corporations, July 1982) (estimating savings at $2-3 \%$, although cautioning that this might overestimate savings because users of finance subsidiaries were those with higher credit ratings).

200. Interest Equalization Tax, Pub. L. No. 88-563, 78 Stat. 809 (1964); 1983 Tax Evasion Hearings, supra note 4, at 800 (statement of Harold Henriquez, Minister for the Netherlands Antilles Affairs, Government of the Netherlands Antilles) ("This sector further developed in the mid nineteen sixties, when foreign borrowing was encouraged (and required) by the various U.S. balance of payments programs."); see generally Robert L. Maines, The Interest Equalization Tax, 17 STAN. L. REV. 710 (1965) (describing various measures employed by the U.S. to address the balance of payments problem, including the Interest Equalization Tax, the purpose of which was to curtail U.S. investment in foreign securities thus reducing the outflow of portfolio capital).

201. 1983 Tax Evasion Hearings, supra note 4, at 585 (Taxecon Associates, Consequences of Imposing the U.S. 30 Percent Withholding Tax on Interest Paid to or by Netherlands Antilles Finance Subsidiaries of U.S. Corporations, July 1982) (estimating savings at $2-3 \%$, although cautioning that this might overestimate savings because users of finance subsidiaries were those with higher credit ratings); 1983 Tax Evasion Hearings, supra note 4, at 168 (statement of Robert Butcher, Vice President, Citicorp) ("No large borrower of funds in the world today can ignore the Eurobond market, for it is a sizeable source of funds, and it is growing more rapidly than the U.S. corporate bond market."). This was not true in the 1960s, when Eurodollar rates exceeded U.S. interest rates on some occasions due to restrictions on U.S. banks' holdings abroad. Marston, supra note 3, at 6. 
used the Eurodollar market to diversify their sources of funds. ${ }^{202}$ From the perspective of foreign investors, the size and stability of the American economy made it a desirable location for the deployment of investment capital. ${ }^{203}$ There was thus both demand for Eurodollars within the United States and an abundant supply of those dollars available for investment into the United States. ${ }^{204}$

Unfortunately for all parties, a U.S. withholding tax on interest payments made by U.S. borrowers to foreign lenders initially made the Eurodollar market prohibitively expensive for U.S. corporate borrowers. ${ }^{205}$ The solution to this problem, like many others in the global capital markets, involved an offshore financial center. Specifically, the Netherlands Antilles and its tax treaty with the United States formed the core of an innovative strategy for avoiding the U.S. tax and providing access to the Eurobond market for U.S. corporate borrowers. To appreciate the Antilles' role in this strategy, however, it is necessary to first understand a bit about international income taxation and the function of tax treaties.

There are two normative bases for income taxation that are recognized in international law: source and residence. ${ }^{206}$ Source-based taxation derives from a state's sovereignty over its territory and the activities taking place within that territory, while residence-based taxation is rooted in a state's sovereignty over its residents. ${ }^{207}$ When a company established in one country earns income in another, the income is potentially subject to taxation by both the company's home (residence) country and the (source) country in which the income is earned. Thus, for example, in the absence of a tax treaty addressing the issue, a Dutch resident earning interest from a debt instrument issued in the United States by a U.S. entity would likely be subject to both residence-based Dutch income tax and source-based U.S. tax. Double taxation of the same income in this manner would quickly bring international cross-border investment to a halt were it not for two mitigating mechanisms employed by many jurisdictions: the "foreign tax credit" and bilateral, double taxation treaties. ${ }^{208}$ The United States and the Netherlands entered into such a treaty

202. 1983 Tax Evasion Hearings, supra note 4, at 175 (statement of Robert Butcher, Vice President, Citicorp).

203. See generally CHARles R. GeISST, ENTREPOT CAPITALISM: ForEIGN INVESTMENT AND THE AMERICAN DREAM IN THE TWENTIETH CENTURY (1992) (describing historical attractiveness of U.S. for foreign investors).

204. The Eurodollar market quickly came to play a key role in the international economy. "Trading firms and corporations with multinational interests have found in the market the flexibility necessary for international operations ... [and it] considerably increased the efficiency of international financing and investment." Marston, supra note 3, at 30. One estimate of U.S. corporate borrowing in the Eurodollar market in 1968-1970 (and so before the large influx into the market of petrodollars produced by the soaring oil prices in the early 1970 s) was $\$ 4$ billion. Id. at 12.

205. In the words of John Chapoton, an Assistant Secretary in the Treasury Department in the 1980s, a withholding tax is "not a tax; it is a barrier to access to foreign debt markets." 1983 Tax Evasion Hearings, supra note 4, at 267 (statement of John E. Chapoton, Assistant Secretary for Tax Policy, Department of Treasury).

206. Nancy H. Kaufman, Fairness and the Taxation of International Income, 29 LAW \& POL'Y INT'L Bus. 145, 148 (1998).

207. In most countries, residence is based on an individual's physical presence within the jurisdiction for roughly half of the taxable year. See, e.g., I.R.C. $\$ 7701(\mathrm{~b})(3)$. The United States also asserts the right to tax the income of its citizens even if they do not reside within the country during the taxable year. See, e.g., I.R.C. $\$ 7701(\mathrm{a})(30)(\mathrm{A})$ (defining a "United States person" as a citizen or resident of the United States).

208. See REUVEN S. AVI-YONAH ET AL., U.S. INTERNATIONAL TAXATION 2-4 (2005) (describing double taxation and the two mitigating mechanisms). 
in 1948 , one of the provisions of which eliminated the thirty percent withholding tax that would otherwise apply to U.S.-source interest payments made to Dutch residents. $^{209}$

Although no one at the time fully anticipated its implications, ${ }^{210}$ the most crucial development in the creation of the Netherlands Antilles' offshore financial sector was the extension of the U.S.-Netherlands tax treaty (and its withholding tax exemption) to the Antilles in 1955 . $^{211}$ The extension was almost an afterthought, accomplished in an atmosphere of postwar goodwill pursuant to a provision of the treaty that permitted its terms to be replicated in new treaties with the overseas territories of either country. ${ }^{212}$ Under the treaty, a U.S. corporate borrower could set up a Netherlands Antilles finance subsidiary (usually a public limited liability company, or "N.V."). ${ }^{213}$ The finance subsidiary would issue Eurobonds to foreign investors and on-lend the proceeds of the bond offering to the U.S. corporate borrower. The U.S. borrower then made interest payments to the finance subsidiary, which would in turn make interest payments to the Eurobond holders. In this manner, U.S. corporate borrowers gained access to the Eurodollar market while the interest payments they made to foreign investors were subject only to residence taxation in their own countries, plus the minimal Antilles tax applicable to the interest-rate spread (profits) retained by the finance subsidiary. ${ }^{214}$

Creation of new Antilles finance subsidiaries sparked an economic boom. ${ }^{215}$ In its review of the years 1969 through 1974, the Antilles' central bank estimated that "billions" of guilders in international capital flowed through the islands, and that by the end of that period-a time when the international finance business had slowed due to changes in U.S. law - the offshore financial sector had paid NAf 35 million

209. Further, the extension of the tax treaty cut the withholding tax on income from U.S. securities to $10 \%$ from $30 \%$. GOV'T. INFO. SERV. (Neth. Antilles), supra note 135, at 49.

210. As one prominent tax lawyer noted later, when the treaty was extended to the Antilles, "nobody knew what an international finance subsidiary was." 1983 Tax Evasion Hearings, supra note 4, at 205 (statement of Marshall J. Langer, Attorney of Counsel, Shutts \& Bowen).

211. LANGER, supra note 9, at 194 (noting the 1955 protocol extending the treaty to the Antilles and stating that the "one major reason for using a Netherlands Antilles company to invest in the United States. ... is to take advantage of favorable provisions contained in the U.S.-Netherlands Antilles income tax treaty.").

212. 1983 Tax Evasion Hearings, supra note 4, at 192 (statement of Marshall J. Langer, Attorney of Counsel, Shutts \& Bowen). The treaty was extended, at least in part, in acknowledgement of the Antilles' post-colonial status as a constituent part of the Kingdom of the Netherlands. 1983 Tax Evasion Hearings, supra note 4, at 51 (statement of William J. Anderson, Director, General Government Division, General Accounting Office) ("Most U.S. tax treaties with tax haven countries are in effect because previous U.S. treaties with developed nations were extended to present and former colonies of those nations).

213. See Löwensteyn, supra note 7,131-32 (explaining that "N.V." is the abbreviation for "naamloze vennootschap," literally "anonymous partnership," the Dutch term for a public limited liability corporation).

214. See supra note 205 and accompanying text; 1983 Tax Evasion Hearings, supra note 4, at 193 (statement of Marshall J. Langer, Attorney of Counsel, Shutts \& Bowen) ("The combination of favorable tax treaty provisions and a special low rate of tax made the Antilles very attractive as a base for foreign investment in the United States.").

215. H.C. BeERs, The Financial Sector of the Netherlands Antilles 33 (1979) ("The emergence of the Netherlands Antilles as a centre of international financial activity basically started with a growth in the number of the so-called finance subsidiaries .... In only a few years, billions of U.S. dollars were channeled from Europe to the United States, through the intermediary of Curaçao finance subsidiaries."). 
(approximately US\$19.6 million) in taxes to the Antilles government. ${ }^{216}$ The success of the offshore sector is also evident in a 1968 study of the Antillean economy that concluded that " $[t]$ he balance of payments would be in continuous deficit, were it not for the remittances by investment companies and by oil companies on account of wages and other payments to be effected in the Netherlands Antilles." ${ }^{217}$

\section{Expanding the Franchise}

The Antilles' finance subsidiary business helped to mature a financial services sector in Curaçao that had begun with accountants and other professionals employed by the refinery and then expanded with the introduction of the Antilles ring-fenced tax scheme. ${ }^{218}$ The increasing sophistication of Curaçao's legal and financial professionals, in turn, led to the development of ever more creative uses for the Antilles N.V., the most popular of the country's business entities. ${ }^{219}$

One of the most important uses was to acquire U.S. real estate and make other investments in the United States, ${ }^{220}$ because an Antilles N.V. offered a number of features that were particularly attractive to foreign investors in U.S. real property and other assets. ${ }^{221}$

First, there were tax advantages when U.S. property was owned through a foreign corporate entity. A foreign investor who sold U.S. real property owned through an Antilles N.V would not be taxed by the United States on gains from the sale of the property, and the N.V. would pay at most the low two and four-tenths percent to three percent Antilles tax applicable to corporate profits on the gain. ${ }^{222}$

216. BANK VAN DE NEDERLANDSE ANTILLEN, supra note 159, at 43. See International Institute of Social History, Value of the Guilder/Euro, supra note 59 (providing conversion rates and calculations).

217. ANDIC \& ANDIC, supra note 25, at 181.

218. As a central bank review noted in 1979:

The infrastructure of the islands, mainly Curaçao and to a lesser extent Aruba and Sint Maarten, is fairly developed. Professional services of bankers, lawyers and accountants are available, as are services of trust companies that undertake the incorporation maintenance and operation of entities.

BEERS, supra note 215 , at 33.

219. Id.

220. 1983 Tax Evasion Hearings, supra note 4, at 59-60 (statement of William J. Anderson, Director, General Government Division, General Accounting Office) (discussing use for stock and bond investments); LANGER, supra note 9, at 187 ("Many sophisticated foreigners investing in U.S. real estate do so through Netherlands Antilles companies."); Interview, Elias, United Trust Co., supra note 13; Interview, Behr, HBM Group, supra note 103; Interview, Paassen-Delsol, Paassen Delsol, supra note 71; John J. Fialka, Closing the Loophole: Corporate Tax Haven in Netherland Antilles is Bracing for Disaster, WALL ST. J., Oct. 11. 1982, reprinted in 1983 Tax Evasion Hearings, supra note 4, at 787-88 (reporting that the CIA believed Arab investors using Antilles structures for privacy and higher interest and that privacy loving Arab investors liked Antilles vehicles).

221. Charles R. Irish, Tax Havens, 15 VAND. J. TRANSNAT'L L. 449, 472-73 (1982) (describing benefits of Antilles company as vehicle for U.S. real estate holdings).

222. 1983 Tax Evasion Hearings, supra note 4, at 194 (Statement of Marshall J. Langer, Attorney of Counsel, Shutts \& Bowen). At the time, the U.S. considered such gain foreign-source income because the selling corporation was not a U.S. resident. This changed in 1980, when the Foreign Investment in Real Property Tax Act (FIRPTA) made the use of N.V. vehicles "somewhat less attractive." 1983 Tax Evasion Hearings, supra note 4, at 59 (statement of William J. Anderson, Director, General Government Division, General Accounting Office) (discussing the avoidance of U.S. tax). For text of FIRPTA, see I.R.C. $\$ 897$ (2009). See also Irish, supra note 221, at 473 ("[T]he sale may be structured so the gain is taxed in neither 
Alternatively, the owners of the N.V. might sell the company (and thus, the real property), and avoid even the Antilles corporate tax, since the sale of the N.V. would not be considered a taxable transaction in the Antilles ${ }^{22.3}$ and there would be no change of ownership of the U.S. real estate recorded in the U.S. to trigger application of any U.S. tax. By contrast, if a foreign investor owned U.S. real property through a U.S. corporation, the selling corporation would be a U.S. resident and the U.S. capital gains tax would be imposed on any gain from the sale. ${ }^{224}$ In addition, a foreign person owning either U.S. real property or shares of a U.S. corporation that owned real property would, at death, be subject to U.S. estate tax on the real property or the shares of the corporation. ${ }^{225}$ However, U.S. estate taxes did not apply if the foreign investor owned U.S. real property through a foreign corporation, like an Antilles N.V., and left the shares to his heirs. ${ }^{226}$

Similar tax benefits applied to other U.S. investments made through Antilles N.V.s. For example, an investor from a country not having a tax treaty with the United States who bought a portfolio of U.S. stocks would pay the thirty percent U.S. withholding tax on the dividends she received. ${ }^{227}$ Moreover, if the investor resided in a country that imposed territorial taxation (as was the case with many Latin American countries), she would not receive a credit against domestic taxes for the U.S. withholding tax paid. ${ }^{228}$ If, on the other hand, the investor purchased the same portfolio of U.S. shares through an Antilles N.V., the entity would pay only the fifteen percent withholding rate applicable under the U.S.-Netherlands Antilles treaty. ${ }^{229}$ U.S. companies also used Antilles' subsidiary companies to hold income-

the United States nor the Netherlands Antilles.").

223. Interview, Elias, United Trust Co., supra note 13.

224. See I.R.C. § 61(a)(3) (2009).

225. I.R.C. § 2101(a) (2002) ("Except as provided in section 2107, a tax is hereby imposed on the transfer of the taxable estate (determined as provided in section 2106) of every decedent nonresident not a citizen of the United States.").

226. 1983 Tax Evasion Hearings, supra note 4, at 179 (statement of Marshall J. Langer, Attorney of Counsel, Shutts \& Bowen); Irish, supra note 221, at 473. So great was the popularity of N.V.s for foreign investment in U.S. real estate investments that with perhaps only slight overstatement, one Curaçao attorney stated that in the 1970s there was "not a building in New York City not owned by an [Netherlands Antilles] company at one time." Interview, Behr, HBM Group, supra note 103. Florida real estate was also often held in Antillean structures. 1983 Tax Evasion Hearings, supra note 4, at 119-20 (statement of Charles Kimball) (estimating that $42 \%$ of foreign acquisitions of real estate in Florida are via anonymous corporations and a majority of those are through Antilles vehicles); id. at 132 (noting 1979 survey found that almost half of foreign investment in South Florida real estate in 1979 was made through foreign corporations, with a majority of those done via the Netherlands Antilles).

227. 1983 Tax Evasion Hearings, supra note 4, at 194 (statement of Marshall J. Langer, Attorney of Counsel, Shutts \& Bowen).

228. Id.

229. Id. Until the treaty was renegotiated in 1963, the less than $3 \%$ tax in the Netherlands Antilles would have provided a total effective tax rate of under 18\%. 1983 Tax Evasion Hearings, supra note 4, at 194 (statement of Marshall J. Langer, Attorney of Counsel, Shutts \& Bowen). See also LANGER, supra note 9 , at 194 . After the 1963 change, the N.V. would pay $15 \%$ tax to the Antilles on its net income. But because of the difference between the application of the U.S. withholding tax to "gross payments" and the Netherlands Antilles tax to "net income," it was comparatively easy to reduce the overall effective tax rate on the investment from $30 \%$ to between 20 to $25 \%$. 1983 Tax Evasion Hearings, supra note 4, at 195 (statement of Marshall J. Langer, Attorney of Counsel, Shutts \& Bowen). See also LANGER, supra note 9, at 197 ("[Effective rates are] invariably less than the U.S. statutory withholding rate of 30 percent."); id. at 199 (explaining how effective rate was reduced to around $24 \%$ in most cases); 1983 Tax Evasion Hearings, supra note 4, at 263 (statement of John E. Chapoton, Assistant Secretary for Tax Policy, Department of Treasury). The U.S. parent could claim a tax credit for any tax paid in the Netherlands Antilles as well. 
generating intellectual property and to obtain comparable tax benefits. ${ }^{230}$ Deductible royalty payments made by U.S. companies to Antilles' subsidiaries could flow into the ring-fenced tax regime of the Antilles free of U.S. withholding tax. ${ }^{231}$

In addition to tax advantages, the N.V. offered anonymity to foreign investors. That is, the identity of the beneficial owners of an N.V. would not appear in public records such as deed registries in the United States, nor would the N.V.'s shareholder list be a public record in the Antilles. ${ }^{232}$ This protected the beneficial ownership of foreign investors in N.V.s from casual scrutiny. ${ }^{233}$ Indeed, an N.V. could issue both bonds and shares of stock in "bearer form" the identity of owners of both debt and equity investments. ${ }^{235}$ This was a particularly important benefit for investors worried about a U.S. backlash against foreign ownership of U.S. assets, like the one against Middle Eastern investors that occurred in the latter part of the $1970 \mathrm{~s}^{236}$ Of course, anonymity was also appealing to those having less savory motives, and it became a source of frustration for U.S. law enforcement authorities who were convinced that the Antilles harbored significant money laundering activities. ${ }^{237}$

Id. After the protocol, interest income net of expenses had to be taxed in the Antilles at the 24 to $30 \%$ rate to be exempt from withholding. 1983 Tax Evasion Hearings, supra note 4, app. 30 at 800 (statement of Harold Henriquez, Minister for the Netherlands Antilles Affairs, Government of the Netherlands Antilles).

230. See 1983 Tax Evasion Hearings, supra note 4, at 195 (statement of Marshall J. Langer, Attorney of Counsel, Shutts \& Bowen).

231. See BEERS, supra note 215 , at 33 ("[Q]uite a large number of offshore investment, holding, royalty, copyright and patent holding companies have been established in the Netherlands Antilles."); LANGER, supra note 9, at 200.

232. The Netherlands ANTILlES-United States InCOME TAX TREATY (Marshall J. Langer ed., 1973), in 1983 Tax Evasion Hearings, supra note 4, at 563 (noting that information is exchanged only to prevent fraud, and is always treated as "secret" and beyond disclosure); see 1983 Tax Evasion Hearings, supra note 4, at 574-77 (Memorandum from the Internal Revenue Service Branch Chief, S. Branch to Assistant Chief, Criminal Investigation Div. Jacksonville Dist. Office (Nov. 23, 1982)) (discussing the treaty stipulation, and Antillen practice, of not sharing information).

233. Note that the Antilles did not have a specific bank, or other, secrecy law but instead relied on general provisions in the criminal code. For example, divulging confidential financial information was punishable by payment of a 60 guilder fine or imprisonment for up to six months under Articles 285 and 286 of the Netherlands Antilles Criminal Code. See 1983 Tax Evasion Hearings, supra note 4, app. 29 at 794-96; see also 1983 Tax Evasion Hearings, supra note 4, at 570 (Memorandum from Peter S. Barash and Dean T. Scott to Chairman and Members of the Subcommittee (Apr. 5, 1983)) (providing example of Florida Real Estate transaction where parties remained anonymous).

234. See the definitions of bearer bonds and shares supra note 9, (describing how bearer bonds and shares are owned by whoever holds them, making them amenable to owner anonymity).

235. 1983 Tax Evasion Hearings, supra note 4, app. 14 at 569 ("The Antilles 'bearer share' concept is unique even among tax treaty countries and enables U.S. and foreign persons to establish companies or financial accounts in the Antilles without disclosing their identities. As a result, I.R.S. agents cannot determine whether an Antillean company or financial account receiving U.S. source income at zero percent withholding is entitled to a tax exemption.").

236. Interview, Elias, United Trust Co., supra note 13; Interview, Paassen-Delsol, Paassen Delsol, supra note 71 .

237. See 1983 Tax Evasion Hearings, supra note 4, app. 14 at 571 (Staff Memorandum, Apr. 5, 1983) ("Eurobonds are tax-free only to foreign persons, but some Eurobonds end up in U.S. taxpayers' hands. Since the bonds are bearer bonds, interest paid to U.S. holders is virtually untraceable. U.S. corporation issued Eurobonds presently total over $\$ 40$ BILLION, with estimated yearly interest payments of nearly $\$ 4$ billion. It is a virtual certainty that U.S. owners of Eurobonds fail to pay taxes on the interest earned. This is a logical surmise because Eurobonds pay 2 to 3 percent less interest than identical bonds issued in the U.S. Only a tax evasion purpose would justify a bond purchase at this lower rate of interest."). 
Finally, the Antilles provided extremely fast service. In the mid-1970s, a previously created shell company could be purchased and put to use in a single business day ${ }^{238}$ at a cost of US $\$ 1,400$ to $\$ 2,000$ (plus $\$ 1,000$ in annual maintenance costs). ${ }^{239}$ With each Antilles N.V. generating approximately US $\$ 1,000$ for the government plus legal and other fees to Antilles' businesses, the creation of offshore companies became extremely lucrative for the Antilles' economy. ${ }^{240}$

Spurred by this success, the Antilles' international business sector sought to expand the range of the jurisdiction's offshore financial services. For example, lured by the lack of insurance regulation, foreign corporations set up a number of captive insurance companies in the Antilles during the $1970 \mathrm{~s}^{241}$ Under a captive insurance arrangement, a U.S. corporation, for example, could self-insure various risks by paying premiums to a wholly-owned insurance subsidiary in a low- or no-tax jurisdiction like the Antilles. ${ }^{242}$ (A principal benefit of captive insurance is that it permits the self-insured corporation to reap the returns on premium dollars invested by the subsidiary. $)^{243}$ By the end of 1976, about sixty Antilles captives were in existence. ${ }^{244}$ Similarly, some early hedge funds created by industry pioneers including George Soros, Paul Tudor Jones, and Julian Robertson established their domiciles in Curaçao from the late 1960 s to the early $1980 \mathrm{~s}^{245}$ Although Antilles corporate law was not perfect for use by hedge funds, and no specific hedge fund entity had been created, the inadequacies of the N.V. structure for funds could be readily resolved, albeit at a cost. ${ }^{246}$ This helped create additional back-office work for the island's trust

238. Fialka, supra note 220 , at 788.

239. LANGER, supra note 9 , at 131.

240. 1983 Tax Evasion Hearings, supra note 4, at 57 (statement of William J. Anderson, Director, General Government Division, General Accounting Office) (listing fees for establishing a new corporation in the Netherland Antilles equaling just under $\$ 1000$ for itemized expenses and stipulating that other charges may occur).

241. BEERS, supra note 215 , at 38 .

242. See Andrew P. Morriss, The Role of Offshore Financial Centers in Regulatory Competition, 15 NEXUS (forthcoming 2010), available at http://papers.ssrn.com/sol3/papers.cfm?abstract_id=1275390 (describing how a company can reduce its costs by self insuring through a captive insurance company).

243. See Gordon A. Schaller \& Scott A. Harshman, Use of Captive Insurance Companies in Estate Planning, 33 AM. C. TR. EST. CouNS. J. 252, 253 (2008) ("However, with a captive insurance company, the parent or related companies will benefit from good claims experience, and surplus in the company may be available to the shareholders by way of dividends.").

244. BEERS, supra note 215 , at 38 . Bermuda ultimately became the dominant jurisdiction in this market in part by developing a specialized statute and regulatory framework for captive insurance. Schaller \& Harshman, supra note 243, at 254. ("The largest venue for captives is Bermuda."); Jan Woloniecki \& Kim Wilkerson, The U.S. Corporate Defendant's Captive Insurer's Dilemma: Third Party Liability Claims and Recovery Under English Law, 73 DEF. Couns. J. 291, 298 (2006) ("Bermuda is ... the world's leading captive domicile (with over 1,500 captive insurance companies incorporated and managed in Bermuda, many of them owned by Fortune 500 companies in the United States) ....").

245. See Susan L. Barreto, The Challenge of Choosing an Offshore Jurisdiction, ReUTERS HEDGEWORLD, May 31, 2002 ("[I]n the 1960s, the Netherlands Antilles was the place. The Antilles was the jurisdiction for hedge fund industry with Paul Tudor Jones, Julian Robertson and George Soros using the islands as the base for their funds....").

246. For example, the Antillean N.V. had a minimum capital requirement of $\$ 30,000$ and requirement of $\$ 1$ share par value. If the stock price fell below par, investors could be liable for corporate debts up to par. The N.V. also required that 20 percent of the shares be outstanding. Antilles attorneys devised various work-arounds, including using multiple classes of stock to both maintain control and meet the various statutory requirements. Interview, Andersen, Eclipse Consulting, supra note 89. 
companies. ${ }^{247}$ As a result, further expertise in hedge fund administration and accounting developed on the island.

These expansions of the Antilles' business came about through new uses of the existing N.V. entity (hedge funds) or absence of regulation (captive insurance) and were not accompanied by legislative action to create new, specialized business entities for specific markets, as began to occur in other, hungrier jurisdictions. ${ }^{248}$ There was also no change in regulatory capacity. The Antilles failed to expand and upgrade its financial regulatory bodies to build confidence in the onshore business and regulatory communities in the Antilles' ability to control illegal activity, as occurred in other jurisdictions. Moreover, the Antilles' continued to require that legal documents be filed in Dutch, a practice one attorney in a competing jurisdiction characterized as "medieval" and which increased transactions costs for non-Dutch companies. ${ }^{249}$ Perhaps lulled into a false sense of security by its monopoly position in the lucrative international finance subsidiary business and distracted by inter-island squabbling and the ongoing struggles over Dutch involvement in insular governance, ${ }^{250}$ the Antilles' government did not innovate. Economist J.R. Hicks noted that "the best of all monopoly profits is a quiet life," to innovate in the 1970 s can be explained as the natural reaction of a monopolist that believed its position to be secure.

\section{E. Trouble on the Horizon}

As the use of the U.S.-Netherlands tax treaty expanded, there were American concerns that persons residing outside the Antilles might engage in "treaty shopping"; that is, gain access to the treaty's benefits by forming Antilles entities that were not technically resident there. ${ }^{252}$ Since, like most treaties from this era, the U.S.-

247. Interview, Andersen, Eclipse Consulting, supra note 89.

248. Morriss \& Boise, supra note 193, at 29; Barreto, supra note 245, ("[S]ince the use of the N.V. fund structure forced managers to pay taxes in the Netherlands Antilles, the hedge fund vehicle became less popular than other fund structures in other jurisdictions, according to AmiCorp. As a result, much of the offshore hedge fund business shifted to the British Virgin Islands in the late 80s or early 90 s. Wholesale legislation was part of the reason for the shift ....").

249. See Interview with Anthony Travers, Chairman, Cayman Is. Fin. Servs. Ass'n (Mar. 9, 2009).

250. For example,

The absence of federally [Antilles-wide] based parties covering more than one island forces Prime Ministers to live in a quandary between the necessities of the whole and those of Curaçao's electorate. A Prime Minister that pays too much attention to the well being of the Netherlands Antilles but is unconcerned with his island runs the risk of losing the insular vote. But a minister that emphasizes the benefits of his electorate will lack support from the parties of the other islands in the task of forming and maintaining the federal government.

Rita Giacalone, The Political Status of Curaçao at the End of the Twentieth Century, in ISLANDS AT THE Crossroads: POLITICS IN THE NON-INDEPENDENT CARIBbEaN 101 (Lynne Reiner Publishers, Inc. 2001) (quoting Rita Giacalone, Freddy Martinez \& Peter Verton, Curazao y Aruba entre la autonomia y la independencia 113-14 (Merida: CDCH-Universidad de Los Andes, 1990)).

251. J.R. Hicks, Annual Survey of Economic Theory: The Theory of Monopoly, 3 ECONOMETRICA 1, 8 (1935).

252. The crucial problem in resolving "treaty shopping" is defining who counts as a resident. The U.S. position was that the treaty was flawed because under Antillean law "most anybody can become a resident, regardless of their citizenship; a resident for purposes of application of the treaty." 1983 Tax Evasion Hearings, supra note 4, at 14 (statement of William J. Anderson, Director, General Government Division, General Accounting Office). See also 1983 Tax Evasion Hearings, supra note 4, at 225 
Netherlands Antilles treaty lacked significant anti-treaty shopping, or "limitation of benefits" provisions, ${ }^{253}$ it proved relatively easy for third-country citizens to create companies in the Antilles in order to secure the treaty's benefits. ${ }^{254}$ The United

(statement of Roscoe L. Egger, Jr., Commissioner, Internal Revenue Service) ("[T]he Netherlands Antilles serves as a useful conduit for payments to nonqualifying recipients in third countries since such payments are subject only to minimal Netherlands Antilles tax. In many cases, companies are set up there strictly to claim reduced U.S. tax rates or exemptions under the Netherlands Antilles treaty while incurring no real tax consequences in the Netherlands Antilles itself."). The result of treaty shopping was, the United States contended, a loss of tax revenue to the investor, since instead of splitting the tax revenue with the investor's tax jurisdiction, both the U.S. and the other jurisdiction gave up some of the revenue. 1983 Tax Evasion Hearings, supra note 4, at 261 (statement of John E. Chapoton, Assistant Secretary for Tax Policy, Department of Treasury). From the Antillean perspective, however, this was just applying a basic international law norm. 1983 Tax Evasion Hearings, supra note 4, at 803 (statement of Harold Henriquez, Minister for the Netherlands Antilles Affairs, Government of the Netherlands Antilles). An important part of the problem was a lack of clear guidelines on what constituted "treaty shopping." 1983 Tax Evasion Hearings, supra note 4, at 196 (statement of Marshall J. Langer, Attorney of Counsel, Shutts \& Bowen). Providing some support for the Antillean position was the Treasury's lack of a model "limitation of benefits provision" for tax treaties. Treasury justified this omission on the grounds that it did not think "a single model would be appropriate" because of the "wide range of international economic relationships and the diversity of foreign tax systems" ... instead, Treasury advocated approaching "each treaty relationship separately." 1983 Tax Evasion Hearings, supra note 4, at 261 (statement of John E. Chapoton, Assistant Secretary for Tax Policy, Department of Treasury). Because there was no data on the extent of "treaty shopping" or other abuses, in part because of the use of bearer shares, neither side was able to produce reliable estimates of the extent of any particular practice. 1983 Tax Evasion Hearings, supra note 4, at 13 (statement of William J. Anderson, Director, General Government Division, General Accounting Office) ("no data" on extent of legitimate compared to illegitimate transactions); id. at 29 ("[I]n many cases, the United States is hard-pressed to detect or deter treaty shopping. This is because many treaty havens liberally define who qualifies as a 'resident' and have bank secrecy laws that prevent I.R.S. from identifying individuals who, in the eyes of the United States, are not bona fide residents of the treaty haven."); 1983 Tax Evasion Hearings, supra note 4, at 92 (statement of Robert Edwards, Deputy Commissioner, Florida Department of Law Enforcement) (Florida law enforcement official thinks, without data, that there is widespread money laundering in the Netherlands Antilles); Douglas $J$. Workman, The Use of Offshore Tax Havens for the Purpose of Criminally Evading Income Taxes, $73 \mathrm{~J}$. CRIM. L. \& CRIMINOLOGY 675, 677 (1982) ("Often the distinction between tax avoidance and tax evasion in the use of foreign tax havens is imprecise because the law governing the transactions is unclear and the requisite data is incomplete."); Milka Casanegra de Jantscher, Tax Havens Explained, 13 FIN. \& DEV. 31 , 31 (1976) (data on tax havens "woefully meager" and "exaggerations flourish"). In the early 1980s, the United States had more than fifty tax treaties, fifteen of which were with tax haven jurisdictions. 1983 Tax Evasion Hearings, supra note 4, at 27 (statement of William J. Anderson, Director, General Government Division, General Accounting Office). See also id. at 47 (" $[\mathrm{W}]$ hen individuals or businesses use tax havens to perpetrate, facilitate, or conceal illegal activities, including tax evasion, it is highly unlikely that routine civil tax enforcement activities will detect many offenders.").

253. Beginning in 1980, the United States began including limitation of benefits provisions in all of its tax treaties as they were renegotiated. Robert H. Dilworth, Financing International Operations of U.S. Multinationals, in 843 TAx LAw AND Estate PlanNing 723, 758 (PLI Tax Law and Practice, Course Handbook Series No. 14322 2008) (noting that "all recent (since 1980) U.S. income tax treaties contain 'Limitation of Benefits' provisions"). Such provisions limit the treaty's benefits to persons who are bona fide residents of the United States or the treaty country. For example, a corporation in a treaty country may not be eligible to receive treaty benefits unless a minimum percentage of its shareholders are individuals who are residents of the treaty country or the United States. See, e.g., U.S. MODEL INCOME Tax Convention, $\S 22$ (1996). See also Vincent P. Belotsky, Jr., The Prevention of Tax Havens via Income Tax Treaties, 17 CAL. W. INT'L L.J. 43, 67-68 (1987) (discussing evolution of limitation of benefits provisions in model treaties); Kenneth A. Grady, Income Tax Treaty Shopping: An Overview of Prevention Techniques, 5 Nw. J. INT'L L. \& BUS. J. 626, 657, n. 3 (1983-1984) (noting that Aiken Industries, Inc. v. Commissioner, 56 T.C. 925 (1971) acq. 1972-2 C.B. 1, the first major treaty shopping case, was not decided until 1971); id. at 634 (first limitations of benefits provision included in U.S. tax treaty in 1962).

254. 1983 Tax Evasion Hearings, supra note 4, at 197 (statement of Marshall J. Langer, Attorney of 
States took the position that treaty benefits were "intended to accrue only to bona fide residents of the treaty country" and that access by de facto residents of nontreaty jurisdictions constituted an abuse of the treaty. ${ }^{255}$ By the early 1980s, U.S. Treasury officials were complaining that the Antilles treaty had become a "one-way treaty with the world" 256 since residents of any country could form an Antillean entity and gain access to the treaty's benefits. Compounding the problem was the fact that the Antilles permitted corporations to issue bearer shares and offered other forms of strong confidentiality. Since these measures prevented U.S. tax authorities from obtaining information on the beneficial ownership of Antillean entities, it was virtually impossible for U.S. tax authorities to limit the use of the treaty to individuals resident in the Antilles. ${ }^{257}$

Restricting access to treaty benefits was important to the United States for several reasons. First, as a "treaty to the world," the U.S.-Netherlands Antilles treaty's cost, in terms of foregone tax revenue, was exponentially greater than it would have been if its provisions had applied only to individuals resident in the Antilles (rather than to companies). Lost U.S. tax revenue from interest and dividends paid to all foreign persons not qualified to receive treaty benefits was estimated to be around $\$ 800$ million in $1982 .{ }^{258}$ The portion of this lost tax revenue

Counsel, Shutts \& Bowen). The problem from the American perspective was that the check on the legitimacy of a transaction occurred only when the Antillean structure was created. As a GAO investigator described it:

[T]he Netherlands Antilles has really done nothing to verify the country of residency of those people who tend to set up, that is those who set up to do business through the Netherlands Antilles .... something like 99 percent of their referrals were generated from U.S. law firms. The Netherlands Antilles accepts the mere affirmation of the attorney involved that in fact this person, this corporation qualifies under the treaty. They do not look beyond that, so therefore you can say they are doing nothing.

1983 Tax Evasion Hearings, supra note 4, at 18 (statement of William J. Anderson, Director, General Government Division, General Accounting Office).

255. 1983 Tax Evasion Hearings, supra note 4, at 29 (statement of William J. Anderson, Director, General Government Division, General Accounting Office).

256. John Cummings, Tiny Islands Are Giant Tax Haven, NEwSDAY, July 31, 1983, reprinted in 1983 Tax Evasion Hearings, supra note 4, at 768; 1983 Tax Evasion Hearings, supra note 4, at 9 (statement of William J. Anderson, Director, General Government Division, General Accounting Office) ("Treasury's primary concern with the existing treaty centers on its belief that it is being used extensively for treatyshopping purposes. In particular, Treasury is concerned about third-country investors' use of the treaty."). Other jurisdictions, too, were negatively affected by their residents' use of the U.S.-Netherlands Antilles treaty. In particular, Latin American governments that taxed income on a territorial basis (as most did in the 1960s) complained that the Antilles treaty was "encouraging flight capital" to the United States. LANGER, supra note 9, at 194-95.

257. 1983 Tax Evasion Hearings, supra note 4, at 570 (Memorandum from Peter S. Barash and Dean T. Scott to the Chairman and Members of the Commerce, Consumer, and Monetary Affairs Subcommittee (Apr. 5, 1983)) (discussing problem of Americans using anonymous corporations to hide income and assets); 1983 Tax Evasion Hearings, supra note 4, at 29 (statement of William J. Anderson, Director, General Government Division, General Accounting Office) ("[I]n many cases, the United States is hard-pressed to detect or deter treaty shopping. This is because many treaty havens liberally define who qualifies as a 'resident' and have bank secrecy laws that prevent I.R.S. from identifying individuals who, in the eyes of the United States, are not bona fide residents of the treaty haven.").

258. Improper Use of Foreign Addresses To Evade U.S. Taxes: Hearings Before the Subcomm. of Commerce, Consumer, and Monetary Affairs of the Comm. on Government Operations H.R., 97th Cong., 2d Sess. 33 (1982); 1983 Tax Evasion Hearings, supra note 4, at 44 (statement of William J. Anderson, Director, General Government Division, General Accounting Office) (noting that there were payments of $\$ 9.6$ billion to foreign persons of U.S. source income in 1981 and that if the 30 percent withholding tax had 
attributable to interest payments made to non-qualified persons through the Antilles was estimated to be in the neighborhood of $\$ 100$ million per year. ${ }^{259}$ Second, the combination of Antilles bearer shares and the Antilles' favorable tax environment produced a significant risk that U.S. taxpayers would use Antilles entities to avoid U.S. income tax, as well-a much more serious problem for the U.S. Treasury. ${ }^{260}$ For example, a U.S. taxpayer paying income taxes at a marginal rate above fifteen percent could form an Antilles' N.V. using bearer shares and then invest through the N.V. into the U.S. securities markets, paying the treaty rate of fifteen percent on dividends and evading the higher income tax he owed. ${ }^{261}$ Third, the United States worried that the widespread use of the Antilles treaty by non-Antillean individuals would reduce the incentive for governments of countries without a tax treaty with the U.S. to negotiate one. ${ }^{262}$ Negotiating such treaties was important to the United States because it could use the offer of a reduction of the thirty percent withholding tax as a bargaining chip to obtain exchange of information provisions that the U.S. Treasury wanted to use to identify tax evasion by U.S. citizens and residents. ${ }^{263}$

applied to all of it, the U.S. would have received $\$ 2.9$ billion in tax revenue instead of the $\$ 727$ million it actually received, although certainly some of the payments were legitimately exempt).

259. See Tim Vettel, Revenue from Antilles Treaty Termination Could Fund $R$ \& $D$ Allocation Proposal, 36 TAX NoTES 1120, 1120 (1987).

260. 1983 Tax Evasion Hearings, supra note 4, at 9 (Statement of William J. Anderson, Director, General Government Division, General Accounting Office) ("[Treasury] suspects that U.S. citizens are taking advantage of the anonymity provided by the Antilles bearer share companies to evade U.S. taxes. For this reason, Treasury is now seeking to incorporate stronger exchange of information and anti-abuse measures in the renegotiated treaty."); Internal Memorandum from Branch Chief S. Branch, Internal Revenue Serv., to Assistant Chief, Criminal Investigation Div. Jacksonville's Dist. Office (Nov. 23, 1983) reprinted in 1983 Tax Evasion Hearings, supra note 4, at 574 ("[T]he government of the Netherlands Antilles will not furnish information concerning returns that are filed and therefore there is no way to dispute these companies claims concerning their reporting of this income in the Netherlands Antilles."). The income tax problem was more serious because by the 1970 s the $30 \%$ withholding tax was largely used as a bargaining chip to persuade countries to negotiate tax treaties. 1983 Tax Evasion Hearings, supra note 4, at 210 (statement of John E. Chapoton, Assistant Secretary for Tax Policy, Department of Treasury). For example, the model U.S. tax treaty provided for complete exemption from it for interest. Id.

261. The practice of citizens or residents investing in their home country through controlled entities resident in an offshore financial center or other tax-favored jurisdiction (e.g., one having a double taxation treaty with the home country) in order to evade taxes sometimes is referred to as "round-tripping." See, e.g., Manjula Chawla and Srinivasa Rao, Should Round Tripping be Banned?, ECON. TIMES, Aug. 25, 2008 available at http://economictimes.indiatimes.com/Opinion/Should-round-tripping-bebanned/articleshow/3400528.cms?curpg=1 (discussing round-tripping by Indian residents using Mauritian entities to take advantage of the India-Mauritius double-taxation treaty); S. Arun, Round-tripped FDI from Tax Havens Under OECD Review, FIN. EXPRESS, Apr. 13, 2009 available at http:/www.financialexpress.com/news/roundtripped-fdi-from-tax-havens-under-oecd-review/446183/.

262. 1983 Tax Evasion Hearings, supra note 4, at 261 (statement of John E. Chapoton, Assistant Secretary for Tax Policy, Department of Treasury); Fialka, supra note 220, at 787 (stating that Treasury believes it cannot get non-treaty countries to negotiate because their nationals are using Antilles structures).

263. 1983 Tax Evasion Hearings, supra note 4, at 50 (statement of William J. Anderson, Director, General Government Division, General Accounting Office) ("Treasury is seeking to include strong exchange of information and anti-abuse measures in all new and renegotiated treaties."); 1983 Tax Evasion Hearings, supra note 4, at 210 (statement of Marshall J. Langer, Attorney of Counsel, Shutts \& Bowen) (Treasury uses the $30 \%$ rate as a bargaining chip). See 1983 Tax Evasion Hearings, supra note 4, at 569 (Staff Memorandum, April 5, 1983) ("Although the Antilles treaty provides generally for the exchange of income information documents between the Antilles Government and the I.R.S., virtually no information is actually exchanged."). 
From the Antilles' point of view, "treaty shopping" was "simply a recently created pejorative term" for a practice based on "the universal norm of treating corporations as separate from their shareholders, and the definition of corporate residence which is framed in terms of the place of incorporation or management of the corporation regardless of the residence of its shareholders." 264 In other words, Antilleans argued that so long as the separate legal existence of corporations was respected, individuals from any jurisdiction should be free to make use of the treaty so long as they complied with Antilles law on the formalities of creating a corporate entity. The treaty-shopping issue had first surfaced in the renegotiation of the treaty in 1962, when the U.S. attempted to make it less attractive to non-Antillean persons seeking to invest in the United States. ${ }^{265}$ The revised treaty did not fully address the U.S. concerns, however, and treaty shopping would be a growing source of conflict between the Antilles and the United States as the use of the treaty became more widespread.

In hindsight, it seems obvious that the volume of Antilles business structures ultimately would provoke a U.S. reaction. The treaty-shopping concern resurfaced in the effort in the early 1970s to eliminate the need for Antilles vehicles by allowing firms to use U.S. subsidiaries to gain access to the Eurocurrency markets, an effort that had some initial success but which, because of drafting flaws, ultimately did not succeed in eliminating Antilles vehicles. ${ }^{266}$ It also featured in the backlash against the use of Antilles N.V.s to acquire U.S. real property. ${ }^{267}$ By as early as $1976,{ }^{268}$ the U.S. had begun discussions with the Antilles and the Dutch about the use of the tax treaty to avoid the withholding tax, suggesting that the treaty's protections might not last forever. And the Internal Revenue Service (IRS) withdrew its sanction of international finance subsidiaries in 1974, causing a short term slump in the market for Antilles subsidiaries. ${ }^{269}$

There were problems developing from another direction as well. Starting in the 1970s, Dutch financial sector companies, including banks and insurance companies, became increasingly international as the size of the financial sector grew from twelve percent to fifty-seven percent of Dutch foreign direct investment (FDI). ${ }^{270}$ Indeed,

264. 1983 Tax Evasion Hearings, supra note 4, at 803 (statement of Harold Henriquez, Minister for the Netherlands Antilles Affairs, Government of the Netherlands Antilles).

265. Interview, Paassen-Delsol, Paassen Delsol, supra note 71. LANGER, supra note 9, at 194-95; Grady, supra note 253, at 638-39 (describing how protocol failed to limit treaty shopping).

266. BEERS, supra note 215, at 33 ("This development has been curtailed because the United States Congress at the end of 1971 and in 1973 enacted legislation designed to encourage the creation of international finance subsidiaries within the United States, in order to eliminate the need for United States companies to make use of subsidiaries in foreign territories, such as the Netherlands Antilles. There are still some deficiencies in the United States legislation and as a consequence some Eurodollar offerings continue to be made through Netherlands Antilles finance subsidiaries, but on a much smaller scale."); 1983 Tax Evasion Hearings, supra note 4, at 201 (statement of Marshall J. Langer, Attorney of Counsel, Shutts \& Bowen) (discussing 1971 legislation).

267. See Jeff Girth, Documents Link Antilles to U.S. Tax Evasion, N.Y. TIMES, Apr. 12, 1983, at A1, reprinted in 1983 Tax Evasion Hearings, supra note 4 (summarizing Dr. Charles Kimball's scandalous reports that favorable treaty conditions allowed wide-scale money laundering, achieved by using N.V.s to purchase real property in South Florida, and reporting that the IRS would investigate these transactions).

268. Interview, Andersen, Eclipse Consulting, supra note 89. The elimination of the withholding tax was proposed in part to gain leverage in negotiations with the Antilles. Cummings, supra note 256, at 768 .

269. Irish, supra note 221, at 468.

270. SluYTERMAN, supra note 1 , at 224. The Dutch service sector became increasingly internationalized due to global liberalization of markets. Id. 
the IRS listed the Netherlands as a tax haven in a 1981 report. ${ }^{271}$ Moreover, as European economic integration increased, Dutch economic interests began to increasingly diverge from the economic interests of the Antilles.

The bonds with the Netherlands were fraying in the political realm as well. Around 1970 "The Hague tried to erase the postcolonial ties laid out in the Charter of $1954 \ldots$... Much to The Hague's disappointment, the Antilles and Aruba ... turned down the 'gift' of the transferral of sovereignty, despite Dutch promises to guarantee their territorial integrity and to continue extending financial support.",272 Finally, even though the offshore sector was lucrative, it failed to outpace the islands' economic problems. The Antilles' GDP per capita remained stuck between $\$ 10,000$ and $\$ 11,000$ from 1960 to 1990 , even as Curaçao's competitors such as the Cayman Islands tripled theirs. ${ }^{273}$

\section{F. "Then Disaster Struck"274}

American dissatisfaction with the use of offshore entities to avoid U.S. taxes increased as the volume of the transactions grew. As one Curaçao attorney termed it, a "new wind" was blowing through the United States Treasury. ${ }^{275}$ Beginning in 1979 , Treasury took an increasingly hard line on "treaty shopping" and "abuses.",776 For example, the United States terminated its tax treaty effective January 1, 1983 with the British Virgin Islands, a tiny jurisdiction with only a small dollar-volume of U.S.-related financial services business, in part to send a signal that the U.S. took the problem seriously. ${ }^{27}$ Six months later, the United States announced it was

271. IRS, TAX HAVENS AND THEIR USE BY UNITED STATES TAXPAYERS - AN OVERVIEW 177 (1981). The Netherlands was also a prime location for treaty shopping:

Tax treaties to which the Netherlands is a party ... are attractive to residents of third countries because the Netherlands is a financial center that imposes no withholding tax on interest paid by Dutch entities to foreign persons, the internal income tax structure is favorable, and the tax treaties provide for favorable treatment of interest income paid to Dutch entities.

Irish, supra note 221 , at 471.

272. OOSTINDIE, supra note 21 , at 15 .

273. OOSTINDIE \& KLINKERS, supra note 6, at 154-55. Oostindie and Klinkers report that Curaçao's GDP per capita was slightly higher than the Antilles' figures during this period, but "'stagnated' around $\$ 12,000$." Id. at 157 .

274. Interview, Elias, United Trust Co., supra note 13.

275. Id.

276. 1983 Tax Evasion Hearings, supra note 4, at 50 (statement of William J. Anderson, Director, General Government Division, General Accounting Office) ("Over the past 5 years, the Treasury Department has become increasingly concerned about tax treaty abuse by both U.S. and foreign investors. In an effort to remedy the problem - which centers primarily on tax haven countries which have treaties with the United States - the Treasury Department has decided to renegotiate all applicable treaties. In so doing, Treasury appears to be taking a hard line approach to renegotiations - an approach which is both warranted and necessary from a tax policy perspective. That is, Treasury is seeking to include strong exchange of information and anti-abuse measures in all new and renegotiated treaties."); see also Belotsky, supra note 253, at 70-71 (describing reasons for U.S. "hard line" on treaty shopping).

277. 1983 Tax Evasion Hearings, supra note 4, at 17 (statement of William J. Anderson, Director, General Government Division, General Accounting Office). The BVI refused to accept information exchange provisions and so Treasury canceled the treaty, sending "a meaningful signal to the international tax community." Id. at 53 . The volume of transactions was relatively low with the BVI, with only $\$ 24$ million paid to BVI residents in 1981. Id. In addition, Treasury thought that the BVI treaty did "stand 
terminating tax treaties with an additional eighteen former British and Belgian territories. ${ }^{278}$ A general policy shift away from tolerating at least some tax-oriented financial intermediation had begun. And with the Netherlands Antilles being one of the top five destinations for payments of U.S. source income to foreigners in the early 1980s, Treasury's attention naturally focused on the islands. ${ }^{279}$

Efforts to renegotiate the treaty with the Antilles began in earnest in $1981,{ }^{280}$ with the United States focused on incorporating provisions for information exchange and the limitation of benefits in the treaty ${ }^{281}$ and the Antilles government resistant to these changes. ${ }^{282}$ By 1983, the IRS had accused the Antilles of accommodating treaty shopping, ${ }^{283}$ Congressional committees began holding hearings on the Antilles

out" in terms of noncompliance. 1983 Tax Evasion Hearings, supra note 4, at 264 (statement of John E. Chapoton, Assistant Secretary for Tax Policy, Department of Treasury). The impact on BVI was substantial, however, as the islands earned $10 \%$ of their national income from offshore banking involving U.S. residents and one result of the treaty cancellation was likely reduced cooperation by the BVI government on other matters. 1983 Tax Evasion Hearings, supra note 4, at 53 (statement of William J. Anderson, Director, General Government Division, General Accounting Office).

278. The jurisdictions were Anguilla, Barbados, Belize, Burundi, Dominica, Falkland Islands, The Gambia, Grenada, Malawi, Montserrat, Rwanda, St. Christopher-Nevis, St. Lucia, St. Vincent the Grenadines, Seychelles, Sierra Leone, Zambia, and Zaire. 1983 Tax Evasion Hearings, supra note 4, at 565 (statement of Marshall J. Langer, Attorney of Counsel, Shutts \& Bowen). Tax treaties with former British colonies Antigua and Barbuda were also terminated effective August 26, 1983. Belotsky, supra note 253, at 90 .

279. See 1983 Tax Evasion Hearings, supra note 4, at 569 (Memorandum to the Commerce, Consumer, and Monetary Affairs Subcommittee) ("The Netherlands Antilles is the world's most widelyused tax treaty country for tax evasion purposes."); 1983 Tax Evasion Hearings, supra note 4, at 44 (statement of William J. Anderson, Director, General Government Division, General Accounting Office) (stating that $68 \%$ of U.S. source payments in early 1980 s were made to residents of Canada, the Netherlands Antilles, the Netherlands, Switzerland, and the United Kingdom, and that a total of $\$ 9.6$ billion was paid to foreign nationals, on which only $\$ 727$ million in withholding tax was paid); If the total amount had been taxed, $\$ 2.9$ billion would have been paid. Id. Some of the untaxed payments were legitimately exempted from the withholding tax in part or entirely under various tax treaties, of course. Id. A Wall Street Journal story quoted Christopher G. Smeets, son of Anton Smeets and the president of the Curaçao International Trust Co., one of the largest firms in the offshore sector, as saying that the American interest in renegotiating the treaty "perhaps" resulted because "my father was too clever ... he did too good of a job ... we became too big too fast and now there are other people ... who have become jealous." Fialka, supra note 220 , at 787.

280. 1983 Tax Evasion Hearings, supra note 4, at 2 ("[S]erious efforts to revise the treaty began in 1981"); 1983 Tax Evasion Hearings, supra note 4, at 7-8 (statement of William J. Anderson, Director, General Government Division, General Accounting Office) (describing how Treasury began a program of tax treaty renegotiation in the late 1970s and took "a hard line approach" in negotiations). 1983 Tax Evasion Hearings, supra note 4, at 571 (Memorandum to the Commerce, Consumer, and Monetary Affairs Subcommittee, (Apr. 5, 1983)) (stating that negotiations formally began in 1979).

281. 1983 Tax Evasion Hearings, supra note 4, at 9 (statement of William J. Anderson, Director, General Government Division, General Accounting Office); 1983 Tax Evasion Hearings, supra note 4, at 273 (statement of John E. Chapoton, Assistant Secretary for Tax Policy, Department of Treasury) (describing a "firm policy" to include limitation of benefits provision in new treaties).

282. I983 Tax Evasion Hearings, supra note 4, at 571 (Memorandum to the Commerce, Consumer, and Monetary Affairs Subcommittee, (Apr. 5, 1983)) (stating that negotiations deadlocked in April 1983 because Antilles will not agree to "all necessary changes"). Antilles government's lack of cooperation is "motivated by the income it collects by imposing a small tax on the dollars flowing into and through the Antilles. It has been estimated that $\$ 100$ million a year is earned by the Antilles Government (or roughly one-third its federal budget) from the small tax imposed on these transactions." Id.

283. Interview, Elias, United Trust Co., supra note 13; 1983 Tax Evasion Hearings, supra note 4, at 9 (statement of William J. Anderson, Director, General Government Division, General Accounting Office) ("Treasury's primary concern with the existing treaty centers on its belief that it is being used extensively for treaty-shopping purposes. In particular, Treasury is concerned about third-country investors' use of 
financial sector, ${ }^{284}$ and J. Roger Mintz, the U.S. Assistant Secretary of the Treasury for Tax Policy, was pushing strongly for repeal of the U.S.-Netherlands Antilles tax treaty, stating that "the United States is a lot better off without it."285 Newspaper accounts of the negotiations suggested that the prospects of a new treaty were growing dim and echoed Treasury's view that the treaty was being abused. ${ }^{286}$ American lawyers and officials were quoted in the media as saying, among other things, "[c]an you imagine anyone in their right mind setting up a system that goes through the Netherlands Antilles," 287 that "[f]or the nation's international capital markets to be so dependent on six tiny islands is ridiculous," 288 and that it was "ridiculous" for U.S. capital markets to be "dependent on a handful of professionals in the Netherlands Antilles." 289

Notwithstanding Treasury's desire to repeal the treaty, the United States also had several policy goals that would be served by keeping it in place. First, the Antilles provided U.S. companies with relatively easy and familiar access to the Eurobond market, making treaty repeal potentially disruptive to financial markets. ${ }^{290}$ Second, domestic political considerations made repeal of the withholding tax difficult. Congress had just created a ten percent "withholding tax" on dividends and interest paid by U.S. entities to U.S. taxpayers. Although this was a true withholding

the treaty. It also suspects that U.S. citizens are taking advantage of the anonymity provided by the Antilles bearer share companies to evade U.S. taxes.").

284. See 1983 Tax Evasion Hearings, supra note 4, at 2 (stating that the Subcommittee "is interested in determining whether the United States and Antilles Governments have been sufficiently diligent in preventing treaty abuses.").

285. Kenneth N. Gilpin, U.S. Keeps Tax Status on Antilles, N.Y. TiMES, July 3, 1987; see also Interview, Elias, United Trust Co., supra note 13 (noting that Mintz was pushing strongly for appeal).

286. See, e.g., Caribbean Tax Haven Faces Heat, CHI. TRIB., Apr. 13, 1983, reprinted in 1983 Tax Evasion Hearings, supra note 4, at 775 (discussing I.R.S. memo on issue leaked to paper); U.S. Seeks New Treaty With Island 'Tax Haven', MIAMI HeRALD, Apr. 14, 1983, reprinted in 1983 Tax Evasion Hearings, supra note 4, at 774 (focusing on the U.S. position); Antilles 'Firms' Help Many Evade Taxes, L.A. TIMES, Apr. 12, 1983, reprinted in 1983 Tax Evasion Hearings, supra note 4, at 771 (discussing House Government Operations Committee staff report).

287. Fialka, supra note 220 , at 788 (quoting a "former Treasury lawyer").

288. James O'Shea, Popular Antilles Tax Haven Poses Catch 22 for the IRS, CHI. TrIB., Nov. 21, 1982, reprinted in 1983 Tax Evasion Hearings, supra note 4, at 778.

289. William Baldwin, The Curaçao Connection, FORBES, Oct. 25, 1982, reprinted in 1983 Tax Evasion Hearings, supra note 4, at 780 (quoting "Washington, DC lawyer H. David Rosenbloom, former international tax counsel at Treasury").

290. See 1983 Tax Evasion Hearings, supra note 4, at 13-14 (statement of William J. Anderson, Director, General Government Division, General Accounting Office). The negotiations themselves caused problems. As a Business Week story on the negotiations in February 1983 noted:

So few clues have leaked out of the treaty talks that 'the international financial community is left in limbo, with huge Eurobond and private financings hung in the balance,' says Richard Hammer, director of international taxes for accounts Price Waterhouse \& Co. Adds General Electric Co.'s tax manager, John McCoy: "This is having an impact. People have been waiting and waiting on this treaty - they're stirred up."

A Treaty That May Sink Havens, Bus. WK., Feb. 14, 1983, reprinted in 1983 Tax Evasion Hearings, supra note 4, at 781. 1983 Tax Evasion Hearings, supra note 4, at 203 (statement of Marshall J. Langer, Attorney of Counsel, Shutts \& Bowen) (noting that the Antilles' "virtual monopoly" on finance subsidiary transactions made it difficult for Treasury to pressure the Antilles into accepting its proposals for a revised treaty); see also 1983 Tax Evasion Hearings, supra note 4, at 571 (Memorandum to the Commerce, Consumer, and Monetary Affairs Subcommittee (Apr. 5, 1983)) (describing how Treasury's leverage is limited because Antilles are only place where Eurobonds can be floated by U.S. firms). 
tax, which allowed a refund of excess amounts collected, it was politically difficult to repeal a tax on foreigners so soon after imposing one with the same name on U.S. taxpayers. ${ }^{291}$ Third, the U.S. needed the Antilles' cooperation in containing illegal drug shipments to the United States. ${ }^{292}$ Finally, the United States had an interest in encouraging political stability in the Antilles. ${ }^{293}$ The importance of the offshore financial sector to the Antilles' economy made this a real concern. ${ }^{294}$ (Lest the reader think this was not considered particularly important, recall that the United States invaded Grenada in October 1983, and Panama in December 1989. ${ }^{295}$ Both invasions evidence an active U.S. foreign policy concern with the Caribbean during the 1980s.) An additional complication was that once the United States had committed to its hard-line position on renegotiations by canceling the BVI treaty, failure to achieve a significant reform of the Antilles treaty would undermine the strong message that had been sent by the BVI cancellation. ${ }^{296}$

291. 1983 Tax Evasion Hearings, supra note 4, at 201 (statement of Marshall J. Langer, Attorney of Counsel, Shutts \& Bowen); William Baldwin, The Curaçao Connection, ForBEs, Oct. 25, 1982, reprinted in 1983 Tax Evasion Hearings, supra note 4, at 780.

292. 1983 Tax Evasion Hearings, supra note 4, at 13-14 (statement of William J. Anderson, Director, General Government Division, General Accounting Office) (describing Antilles' intelligence on drug trafficking as "of vital importance" to U.S. antinarcotics activities).

293. Id. at 55 (noting that negotiations were complicated because "the economy of the Netherland Antilles, a pro-American Caribbean country, depend[ed] very heavily on offshore banking activities"); "[W]hile it is clear, from a tax policy perspective, that the U.S. can no longer tolerate extensive abuse of the current tax treaty, other concerns come into play. The status of the Netherlands Antilles' economy is one such concern[... .]" Id. at 64; Cummings, supra note 256, at 769 (noting that the United States had an important interest in "buttressing the economies of Caribbean nations against Marxist penetration" and feared that the Antilles could be vulnerable).

294. A Treaty That May Sink Havens, BUS. WK., Feb. 14, 1983, reprinted in 1983 Tax Evasion Hearings, supra note 4, at 782. ("[T]he Antilles minister in Washington [noted], 'Tourism, our No. 1 industry, is uncertain. Oil, No. 2, is uncertain. We need the offshore investment business. It produces $25 \%$ or $30 \%$ of our $\$ 120$ million federal budget ... If we lose our tax haven, our unemployment rate ... would go from $20 \%$ to $27 \%$." ").

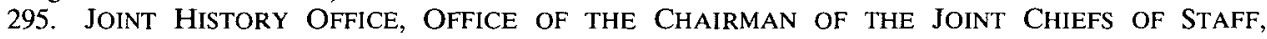
Operation URgent Fury Grenada: The PlanNing and EXECUTION OF JoINT Operations IN GRENADA 12 OCTOBER-2 NOVEMBER 1983 (1997); JOINT HISTORY OFFICE, OFFICE OF THE CHAIRMAN of THE JOINT ChIEFS OF STAFF, OPERATION Just CaUse Panama: THE PlanNing and EXECUTION OF JOINT OPERATIONS IN PANAMA FEBRUARY 1988-JANUARY 1990 (1995).

296. 1983 Tax Evasion Hearings, supra note 4, at 17 (statement of William J. Anderson, Director, General Government Division, General Accounting Office). There were alternative means of accomplishing some of these U.S. policy goals. The need for the Antilles route to the Eurobond market was a result of the U.S. withholding tax. The U.S. could either repeal the tax or give another jurisdiction tax treatment similar to that given to the Antilles but in a treaty with limitation of benefits provisions. Id. at 10 (noting that access to the Eurobond market could be "just as easily achieved by changing or eliminating the withholding tax requirement applicable to such borrowings-something that Treasury itself has proposed in the past."); 1983 Tax Evasion Hearings, supra note 4, at 277 (statement of John E. Chapoton, Assistant Secretary for Tax Policy, Department of Treasury) (noting that Treasury favored repeal of withholding tax on certain forms of interest paid to foreign persons, including Eurodollar loan interest); 1983 Tax Evasion Hearings, supra note 4, at 168 (statement of Robert Butcher, Vice President, Citicorp) (noting that Citibank had repeatedly called for repeal of the withholding tax); id. (noting that UK had proposed to change its law to allow direct payments to overseas payment agents without a withholding tax in March 1983); 1983 Tax Evasion Hearings, supra note 4, at 204 (statement of Marshall J. Langer, Attorney of Counsel, Shutts \& Bowen) (suggesting creating a competitive center). There were potentially more cooperative jurisdictions. For example, Switzerland cooperated with the United States by determining if the withholding tax exemption under the treaty was appropriately invoked or not. Where it was not, the Swiss collected the withholding tax and sent it to the United States. 1983 Tax Evasion Hearings, supra note 4, at 9 (statement of William J. Anderson, Director, General Government Division, General Accounting Office). The islard of Guam, a U.S. dependency, took steps to establish 
The Antilles wanted to maintain its offshore financial sector and therefore sought to make the 1980s negotiations with the United States successful. The Antilles were prepared to agree to share with the U.S. Treasury information about American citizens and residents, but not information about residents of other countries. $^{297}$ The sticking point appeared to be the shared belief by the United States and the Antilles that the latter's offshore financial sector could not survive the information-sharing and limitation-of-benefits provisions the United States was demanding. ${ }^{298}$ Both believed that a new treaty acceptable to the United States would spell disaster for the existing offshore business; they disagreed on the desirability of that outcome. There was thus a real impediment to a new agreement that could not be resolved through negotiation.

The U.S. increased pressure on the Antilles by repealing the U.S. withholding tax on interest payments effective July $18,1984 .^{299}$ (There was, and continues to be, a general trend toward the repeal of such taxes worldwide as part of the opening of

itself as a potential competitor to the Netherlands Antilles, but Treasury acted swiftly to block the effort. See The Next Tax Haven Could Be Guam, USA TODAY, Oct. 12, 1982, reprinted in 1983 Tax Evasion Hearings, supra note 4, at 740; Gordan C. Chang, Guam May Replace Antilles as Popular Tax Haven, WALL ST. J., Oct. 3, 1982, reprinted in 1983 Tax Evasion Hearings, supra note 4, at 741; Letter from Ricardo J. Bordallo, Governor of Guam, to President Ronald Reagan (Jan. 7, 1983) (reprinted in 1983 Tax Evasion Hearings, supra note 4, at 731) (objecting to IRS efforts to block Guam's efforts). However, neither of these alternatives were themselves cost-free. In addition, any change in U.S. policy would have to take into account the impact on the existing bond market. Most Eurobonds required the borrower to "gross up" any taxes that ultimately might be imposed on the interest payments due on the bonds. Eurobonds issued through the Antilles typically required that the borrower "gross up" the bond (i.e., pay the cost of any taxes imposed). 1983 Tax Evasion Hearings, supra note 4, at 175 (statement of Robert Butcher, Vice President, Citicorp). This provision applied only to non-U.S. persons holding the bonds, however, thus deterring Americans from attempting to avoid taxes by purchasing bearer Eurobonds issued by U.S. companies rather than U.S. bonds issued domestically by the same borrower. Id. at 176 . As a result, a change in U.S. policy that caused the imposition of withholding taxes would be extremely costly to U.S. borrowers.

297. John Cummings, Tiny Islands Are Giant Tax Haven, July 31, 1983, NEwSDAY reprinted in 1983 Tax Evasion Hearings, supra note 4, at 768-69; 1983 Tax Evasion Hearings, supra note 4, at 807-08 (statement of Harold Henriquez, Minister for the Netherlands Antilles Affairs, Government of the Netherlands Antilles).

298. 1983 Tax Evasion Hearings, supra note 4, at 9-10 (statement of William J. Anderson, Director, General Government Division, General Accounting Office) ("The Netherlands Antilles has not taken any unilateral actions to remedy treaty-related abuses, nor is it expected to soon do so, absent a treaty with revisions. This is because, according to Netherlands Antilles officials, such actions would have the effect of essentially closing down the offshore financing business in that country. Thus, absent strong action, Treasury cannot soon expect to reverse the growth in, much less halt, undesirable use of the U.S. tax treaty with the Netherlands Antilles."); Belotsky, supra note 253, at 83 ("There is little incentive, however, for tax haven countries such as the Netherlands Antilles to make concessions in a new treaty which the United States would regard as meaningful.").

299. Interview, Elias, United Trust Co., supra note 13; Interview, Andersen, Eclipse Consulting, supra note 89; Deficit Reduction Act of 1984, Pub. L. No. 98-369 § 127(a), 98 Stat. 494, 648-50 ("Repeal of the 30 Percent Tax on Interest Received by Foreigners on Certain Portfolio Investments."). See also Michael J. Gratz and Itai Grinberg, Taxing International Portfolio Income, 56 TAX L. REV. 537, 577 n.186 (2003) (discussing the effects of the repeal of the withholding tax); Leslie E. Papke, One-Way Treaty With the World: The U.S. Withholding Tax and the Netherlands Antilles, 7 INT'L TAX \& PUB. FIN. 295, 295 (2000) (exploring broad impacts of the repeal of the withholding tax); Chris R. Carson, Nonresident Alien Income and Tax Withheld, 1983, available at http://www.irs.gov/pub/irs-soi/83nonralintw.pdf (noting that the Deficit Reduction Act of 1984 was "expected to all but eliminate the use of the Antilles for future Eurobond financing"). 
capital markets. $)^{300}$ The repeal diminished the attractiveness of the Antilles sandwich structure by removing an obstacle to directly tapping the Eurobond market. ${ }^{301}$ The repeal did not eliminate it entirely, however, because the Antilles sandwich structure was useful as a conduit to move cash offshore into subsidiaries in lower tax jurisdictions. That is, a U.S. corporation could make deductible interest payments to a finance subsidiary at an interest rate higher than the rate paid by the subsidiary on the Eurobonds it issued to foreign investors. The "spread" between the two interest rates was profit to the finance subsidiary in the Antilles and subject to that jurisdiction's low corporate tax rates. The greater the interest rate spread, the more U.S. earnings of the corporation (in the form of deductible interest payments) escaped U.S. taxation. That money could then be used to fund foreign operations.

In 1982, the United States again increased pressure on the Antilles as IRS field offices began to question the tax status of Antillean finance subsidiaries. ${ }^{302}$ Not only did IRS field offices begin to dispute withholding tax exemption claims during audits, but on March 9, 1983, Treasury denied the Federal National Mortgage Association's request to establish a Netherlands Antilles finance subsidiary because the department feared approval "could have an adverse effect on our negotiations [over the tax treaty], which currently are at a sensitive stage. ${ }^{303}$

Although there were reports that the United States had made its "final, bottomline offer" in early $1983,{ }^{304}$ the pressure must have had some impact on the

300. Interview, Behr, HBM Group, supra note 103; Mitchell B. Weiss, International Tax Competition: An Efficient or Inefficient Phenomenon?, 16 AKRON TAX J. 99, 108 \& n.27 (2001) ("Thus, not surprisingly, one country after the next responded in kind [to the repeal of U.S. withholding tax on interest income], introducing measures that not only discouraged the outbound migration of their country's capital, but also encouraged the importation of large amounts of capital from higher-taxing jurisdictions. Some countries created tax-exempt domestic investment opportunities; some relaxed their enforcement efforts; but most followed the U.S.'s lead, exempting their withholding tax on imported interest income and substantially cutting their corporate and individual tax rates."); see Maines, supra note 200 (describing various U.S. measures employed to curtail outbound flows of capital); Interest Equalization Tax, Pub. L. No. 88-563, 78 Stat. 809 (1964).

301. Interview, Andersen, Eclipse Consulting, supra note 89.

302. 1983 Tax Evasion Hearings, supra note 4, at 263 (statement of John E. Chapoton, Assistant Secretary for Tax Policy, Department of Treasury) (noting IRS inquiry into the appropriateness of tax treatment of Antilles entities and tax status "not entirely settled"); William Baldwin, The Curaçao Connection, FoRBES, Oct. 25, 1982, reprinted in 1983 Tax Evasion Hearings, supra note 4, at 780 (reporting on Houston I.R.S. office's attempt to limit benefits of treaty to Curaçao residents). See also 1983 Tax Evasion Hearings, supra note 4, at 65 (statement of William J. Anderson, Director, General Government Division, General Accounting Office) ("[The I.R.S.] did not challenge continued and expanded use of such finance subsidiaries by U.S. corporations until 1982. At that time, of course, Treasury was involved in renegotiating the Netherlands Antilles tax treaty."); Letter to Roscoe Egger, Jr., I.R.S. Commissioner, from Price Waterhouse \& Co. (Sept. 29, 1982) (reprinted in 1983 Tax Evasion Hearings, supra note 4, at 608) (expressing concern over the "newly established position" of the I.R.S. on finance subsidiaries, which it contends is a "sharp reversal of long standing practice"); James O'Shea, Popular Antilles Tax Haven Poses Catch 22 for the IRS, CHI. TRIB., Nov. 21, 1982, reprinted in 1983 Tax Evasion Hearings, supra note 4, at 776-77 (describing impact of disclosure in Texas Air Corp. SEC filing of tax dispute with IRS over Antilles finance subsidiary).

303. Letter from Donald T. Regan, Secretary of the Treasury, to Donald O. Maxwell, the Chairman of the Board \& Chief Executive Officer of the Federal National Mortgage Association (Mar. 9, 1983) (reprinted in 1983 Tax Evasion Hearings, supra note 4, at 612). A media report focused on the incongruity of a federal entity attempting to avoid federal taxes. Fialka, supra note 220 , at 788 ("'Here was a federal agency that wanted to go through the Antilles to escape a federal tax,' one former official noted. 'I found that mind boggling." ").

304. Memorandum from the 1983 Tax Evasion Hearings, supra note 4, at 571-72 (April 5, 1983) (describing offer as including exchange of information). 
Antillean negotiators, for in April 1983 Treasury reported that "most of the issues" between the United States and the Antilles had been resolved and a new treaty would be signed "in a matter of weeks or months at the most." ${ }^{305}$ No treaty was forthcoming, however, and efforts to finalize a renegotiated treaty dragged on from 1983 to $1986 .^{306}$ Although a new treaty was initially agreed to by the two governments, it failed to be ratified, in part because subsequent changes to U.S. tax law in the 1986 tax reforms were inconsistent with the new treaty. ${ }^{307}$ Rather than a new treaty, on June 29, 1987, Assistant Treasury Secretary Mintz announced that the United States would cancel its tax treaty with the Antilles in six months. ${ }^{308}$

The announcement caused chaos in international markets because of the impact of treaty cancellation on the $\$ 40-50$ billion of outstanding bonds that had been issued in reliance on the treaty exemption prior to the U.S. repeal of the withholding tax ${ }^{309}$ The repeal of the tax had been prospective only, leaving interest payments on bonds issued prior to repeal subject to the withholding tax unless covered by a tax treaty. ${ }^{310}$ Thus, cancellation of the U.S.-Netherlands Antilles tax treaty had the effect of making all interest payments on bonds issued prior to the withholding tax repeal subject to withholding tax. Since these bonds generally made the borrower responsible for any taxes or interest payments, this would cost U.S. borrowers thirty percent of future interest payments, although many bonds also permitted redemption under such circumstances. ${ }^{311}$ To prevent the instability in the bond market this would

305. 1983 Tax Evasion Hearings, supra note 4, at 265 (statement of John E. Chapoton, Assistant Secretary for Tax Policy, Department of Treasury).

306. Interview, Elias, United Trust Co., supra note 13.

307. Mark B. Schoeller, Comment, The Termination of the United States-Netherlands Antilles Income Tax Convention: A Failure of U.S. Tax Policy, 10 U. PA. J. INT'L BUS. L. 493, 506-07 (1988).

308. See Treas. Dep't. News Release 87-3894 (June 29, 1987); see generally Rose Gutfeld \& Ann Monroe, U.S. Is Ending 1948 Tax Treaty With the Antilles, WALL ST. J., June 30, 1987, at 7; Interview, Elias, United Trust Co., supra note 13. At the same time, the United Kingdom announced it would review its tax treaty with the Antilles (although with less effect, as there were far fewer Antilles finance subsidiaries owned by British corporations). See Britain Reviews Tax Pact With Netherlands Antilles, WALL ST. J., July 2, 1987, at 30; Interview with Guiveron T. Weert \& Errol Gova, Bank van de Nederlandse Antillen, Curaçao, Netherlands Antilles (May 21, 2008) [hereinafter Interview, Weert \& Gova, Bank van de Nederlandse Antillen]; Interview, Paassen-Delsol, Paassen Delsol, supra note 71.

309. Interview, Elias, United Trust Co., supra note 13; Kenneth N. Gilpin, U.S. Keeps Tax Status on Antilles, N.Y. TimES, July 3, 1987, at D1 (noting that the announcement of the treaty cancellation "sent shock waves through the bond markets worldwide," causing losses in value of "as much as seven points" in some bonds' value, because it would have subjected $\$ 32$ billion in corporate debt sold through the Antillean subsidiaries to the withholding tax and would likely prompt issuing companies to redeem them and refinance); James A. Duncan \& Albert S. Pergam, Euromarket participants evaluate treaty revocation, 6 INT"L FIN. L. REV. 12, 12 (1987) (noting that Reagan administration was "[s]tung by the vehemence of the response to its revocation of the treaty" and moved quickly to modify the treaty cancellation to protect existing bonds).

310. Interview, Elias, United Trust Co., supra note 13; Interview, Andersen, Eclipse Consulting, supra note 89.

311. Duncan \& Pergam, supra note 309, at 13 ("Eurobond documentation typically requires issuers to bear the cost if such taxes are imposed after the bonds are issued (by paying additional interest sufficient to offset the amount of any taxes required to be withheld from interest payments), but permits issuers to redeem outstanding obligations at par if this obligation to 'gross up' interest payments is triggered."). Eurobonds differed significantly with respect to the call provision. Where bonds were immediately callable, issuers benefited as they could refinance at lower rates after redeeming at par bonds currently selling above par. Where bonds were not immediately callable, issuers faced higher interest payments. Id. at $13-14$. 
have produced, the United States quickly reinstated the treaty exemption from withholding tax (Article VIII) for interest paid on existing bonds. ${ }^{312}$

While the Antilles' Finance Minister called the cancellation of the treaty "a national disaster," ${ }^{, 313}$ media coverage in the United States-even in the pro-business Wall Street Journal-was unsympathetic. A page-one Journal report on the treaty cancellation concluded with an anecdote about "Juan Fulano" (Spanish for John Doe), a mysterious "fat man" in a "dark corner of one of Curaçao's finest hotels" confiding at 3:15 a.m. that the Antilles were the "ideal" offshore jurisdiction because they were "Pros. Discreet .... In the Antilles, you rarely have to pay a bribe, and you almost never have to pay a tax."

Shorn of the treaty that had been the cornerstone of its financial strength, the mighty Antilles was now as powerless in the face of growing competition from other offshore jurisdictions as Samson before the Philistines. In particular, the Antilles confronted a substantial threat from zero-rate or "nil" tax jurisdictions like the Cayman Islands and the British Virgin Islands ${ }^{315}$ that had expanded dramatically in the $1980 \mathrm{~s}^{316}$ Not only did these jurisdictions offer a zero tax rate, making a tax treaty superfluous for some financial structures, but they also offered familiar, commonlaw, English-language legal systems. By contrast, the Antilles' civil-law, Dutchlanguage system became even less attractive than it previously had been to Americans considering doing business there. ${ }^{317}$ Finally, legal ethics rules governing Dutch and Antilles' lawyers prohibited them from advertising legal services, further handicapping them in competition against the lawyers in Cayman and other jurisdictions who were subject to no such restrictions. ${ }^{318}$ The result was that the Antilles "got slaughtered" and "absolutely run over" in the market and the use of N.V.s by foreign business was never again a significant part of the financial sector. ${ }^{319}$

\section{REGIME FLEXIBILITY, THE ANTILLES, AND THE FUTURE OF OFFSHORE FINANCIAL INTERMEDIATION}

It seems unlikely that anyone forecasting the future of the world financial system at the close of World War II would have predicted that the Antilles would play a major role in it. Not even Anton Smeets, the entrepreneurial notary who laid the foundations for the Antilles' offshore financial sector, likely anticipated that Antilles corporations would be vehicles for significant real property and other investment holdings in the United States in the 1970s, or that billions of dollars in Eurobonds would be issued through the Antilles' finance subsidiaries in the early 1980s. It also does not appear that many in the Antilles foresaw the abrupt end of the boom in the mid-1980s. In retrospect, however, we believe that from the

312. See Treas. Dep't. News Release 87-4404, (July 10, 1987); see also Gilpin, supra note 285; Interview, Elias, United Trust Co., supra note 13.

313. McCoy, supra note 29.

314. Id.

315. Irish, supra note 221, at 456 (characterizing the Cayman Islands and British Virgin Islands as pure tax havens).

316. Interview, Weert \& Gova, Bank van de Nederlandse Antillen, supra note 308; Interview, Andersen, Eclipse Consulting, supra note 89.

317. Interview, Andersen, Eclipse Consulting, supra note 89.

318. Id.

319. Id. 
experience of the Antilles one can discern the contours of a theory that explains the relatively brief arc of that jurisdiction's success as an offshore financial intermediary and offers insight into the future prospects of both the Antilles and other offshore financial centers in the twenty-first century. This section sets out the elements of that theory.

\section{A. A Theory of Regime Plasticity ${ }^{320}$}

The rise and fall of the Antilles suggests four critical propositions for the offshore financial sector at large. First, there will always be differences among legal regimes, and those differences often may be arbitraged in order to make business transactions more cost-efficient. This arbitrage may be financially beneficial not only to the parties to the transactions but also to the jurisdiction in which the transactions take place if the jurisdiction can attract a sufficient volume of such transactions. Second, differences among legal regimes, while persistent, are nonetheless fluid, which makes the revenue flows realized by jurisdictions engaged in financial intermediation particularly vulnerable through changes in both business conditions and in the legal regimes that produce the intermediation opportunities. Third, the vulnerability of offshore jurisdictions to the elimination of revenue flows from financial intermediation activity places a premium on a jurisdiction's legislative agility. To survive in a world of perpetual change, an offshore jurisdiction must develop the ability to adapt quickly to change. Finally, whether an offshore jurisdiction can adapt to changes in business conditions and the alteration of legal regimes in onshore jurisdictions depends in great part on its own laws and the political arrangements under which it exists. Each of these propositions is addressed in turn in the following sections.

\section{The Persistence of Difference}

Although many jurisdictions' tax and regulatory systems have broad principles in common, differences in details are inevitable. Some such differences reflect policy choices, simple drafting preferences not related to policy concerns, or even inadvertent errors. We contend that such distinctions are an inevitable result of the inherent complexity of modern tax and regulatory systems coupled with strategic behavior by some jurisdictions seeking to attract business through manipulation of their regulatory regimes. As Erin O'Hara and Larry Ribstein recently noted, governments often fail to effectively control everyone everywhere. ${ }^{321}$ Any state can make rules, but not every state legitimately can enforce them in all circumstances, especially those involving people or assets outside the state. ${ }^{322}$ Because no single government can extend its courts and enforcement powers to cover the world, multiple states end up competing with no state able to exercise effective monopoly power over mobile entities. ${ }^{323}$ In the end, the states compete for mobile parties and their assets by attempting to provide the laws people want. ${ }^{324}$ Even resolute efforts at

320. See definition of "plasticity" supra note 15.

321. O'HARA \& RIBSTEIN, supra note 87, at 60.

322. Id.

323. Id.

324. Id. 
harmonization cannot eliminate jurisdictional variations entirely, and most harmonization efforts fall short of the level of effort needed to characterize them as "resolute." Differences arise both by intention and accident, and even accidental ones acquire constituencies once they have been in existence for a time.

Regardless of the rationale or lack thereof for any particular legal difference, as such differences multiply, opportunities arise to structure transactions to arbitrage them. The Antilles' ascendancy began with its creation of a tax regime that differed from and was more favorable to foreign investors than tax regimes in other jurisdictions. It continued with the subsequent identification and exploitation of an opportunity to use Antilles entities and treaty relationships to permit access by U.S. borrowers to the fiscal resources of the Eurobond market-access that was not available on the same terms through U.S. or other foreign entities. As tax expert Marshall Langer noted in his 1983 Congressional testimony about the use of Antilles finance structures by U.S. firms, it was not Antilles law alone that produced the demand for Antilles finance structures, but rather its interplay with U.S. law. ${ }^{325}$ Of course, specific transactions depended on a multitude of details concerning everything from U.S. tax policy to European relaxation of currency controls and from declining communications costs to the increasing sophistication of legal counsel. However, it was the persistence of differences in the two legal regimes that propelled the Netherlands Antilles from a largely forgotten backwater to financial sector prominence.

Since difference has always been persistent, why is it that it has not always led to successful arbitrage? Historically, the exploitation of differences in legal regimes has been limited by the costs associated with cross-border transactions. These costs include providing adequate communications capabilities between two or more geographically distant jurisdictions; securing the services of lawyers, bankers, accountants, notaries, and other professionals in each jurisdiction to implement the transactions; and contending with the regulatory risks associated with doing business across multiple jurisdictions. All three of these, but particularly the first two, have been reduced dramatically for virtually all jurisdictions since World War II, greatly expanding the range of possibilities for exploiting arbitrage opportunities.

The history of the Antilles discussed in Part I highlights the steadily declining communications and professional services costs that, in the $1950 \mathrm{~s}$, began to shape the islands and eventually helped persuade firms to engage in international financial intermediation there. The original "offshore" transaction in the Antilles was the relocation of the statutory seats of Dutch multinationals at the outbreak of World War II. Prior to that time, communication between Europe and the Antilles was deemed too expensive, and the cost of securing professional infrastructure too high to make doing business in the Antilles feasible. The German invasion changed the equation, because the cost of remaining in the occupied Netherlands became greater for Dutch companies than the costs of going offshore. Today, the ongoing decline in the cost of communications-what The Economist has termed "the death of distance" $" 326$ - continues to make the Antilles and similar, previously remote locations viable places in which to do business.

325. 1983 Tax Evasion Hearings, supra note 4, at 200 (statement of Marshall J. Langer, Attorney of Counsel, Shutts \& Bowen).

326. See Frances Cairncross, The Death of Distance: How the Communications Revolution Will Change OUR Lives (2d ed. 2001). Cairncross's book was an expansion of her original article in The Economist, in which she coined the phrase "the death of distance." See The Death 
Communications costs are not the only costs that have declined dramatically; the costs of securing professional services have also been reduced over time. Once Dutch firms began to establish themselves in the Antilles during the war, a professional services sector quickly sprang up to serve those companies. This made it possible to secure the professional services necessary to engage in financial transactions in the Antilles at a reasonable cost. Moreover, as the professional services infrastructure in a jurisdiction expands and becomes more sophisticated, ever-smaller legal regime differences become susceptible to cost-effective exploitation.

In addition, as familiarity with the Antilles legal regime grew following the advent of Dutch companies to the jurisdiction, the real or perceived regulatory and transactions costs of doing business in what some viewed as a half-forgotten colonial outpost also diminished. The early establishment of offshore financial activity gave the Antilles a taste of the benefits a financial sector could offer, thus providing an incentive for continued private sector and local government cooperation in the establishment of the sector, and further reducing future regulatory risk. This "virtuous circle" was subsequently repeated in the development of the Antilles' tax regime, the finance subsidiary business, and the use of Antilles N.V.s for foreign investment in U.S. real property and other assets.

Ironically, the decline in the regulatory risks of doing business offshore is attributable, in part, to the successful efforts of onshore jurisdictions to control competition in at least the more reputable offshore jurisdictions through international standards for anti-money laundering measures and the prevention of organized crime. Pushed by multilateral regulators, onshore jurisdiction law enforcement agencies, and competition amongst themselves, offshore jurisdictions have brought their financial systems into the twenty-first century (and in some instances have surpassed onshore jurisdictions), achieved compliance with international standards from organizations like the Financial Action Task Force (FATF), ${ }^{327}$ and joined key certification organizations such as the International Organization of Securities Commissions (IOSCO) ${ }^{328}$ No longer as easily dismissed as tax havens sullied by "the Grisham effect," the legal structures they offer have become a central element of the business structures of many multinational corporations. There may not be a single transaction as lucrative as the Antilles' sandwich was at its peak, but because important jurisdictional differences in tax and regulatory policies persist, opportunities for offshore financial intermediation will not disappear.

of Distance, THE ECONOMIST, Sept. 30, 1995, at S5.

327. FATF is an inter-governmental body established by the G-7 Summit in 1989 to develop and promote national and international policies to combat money laundering and terrorist financing. See generally http://www.fatf-gafi.org (follow "About the FATF" hyperlink) (last visited Oct. 6, 2009).

328. Formed in 1983, IOSCO is a global organization of securities regulators that is recognized as the international standard setter for securities markets. See generally http://www.iosco.org/about/ (last visited Oct. 6, 2009) (providing general information on the organization and more specific information under the "Historical Background" tab).

329. John Grisham's popular novel The Firm, which was subsequently made into a blockbuster movie, featured the use of secret bank accounts in the Cayman Islands as a means of hiding ill-gotten gains. Grisham took artistic liberties with the details of Caymanian banking to suit the needs of the novel, and gave readers an inaccurate picture of Caymanian banking practices and law. See generally JOHN GRISHAM, THE FIRM (Dell Publishing Company 1992). 


\section{The Challenge of Change}

The second proposition one may derive from the Antilles' experience is that differences among various legal regimes are fluid, rather than static. Thus, no particular opportunity for intermediation based on legal differences can last forever. Just as the coral reefs in Curaçao that shelter an astonishing array of sea life may be damaged by changes occurring elsewhere in the ocean, ${ }^{330}$ so changes in the laws and regulations of one or more onshore jurisdictions may threaten financial intermediation transactions and the viability of the offshore financial centers through which they are conducted. Consequently, offshore centers like the Netherlands Antilles remain vulnerable because they cannot control whether, or for how long, the transactions on which they depend will remain economically viable.

Of course, international transactions are vulnerable to all sorts of change. A trading partner could institute a tariff or close its borders to imports; transportation costs could rise; or a new competitor could appear, capture market share and eliminate its predecessor. For the Antilles, this kind of change appeared in the form of a major competitive threat from commonwealth Caribbean jurisdictions such as the Cayman Islands and British Virgin Islands. But there is a different kind of vulnerability to change associated with offshore financial centers that relates to their ability to craft and enact laws that create exploitable differences between their own legal regimes and those of onshore jurisdictions. Financial intermediation that exploits legal differences frequently results in lost tax or business revenue for onshore jurisdictions. Thus, an offshore financial center must be concerned about the effects on onshore jurisdictions of the legal differences it creates. Because financial intermediation ultimately depends on all jurisdictions involved maintaining the legal regimes that permit it, once the costs of intermediation activity to one of the jurisdictions exceed its benefits, that jurisdiction has an incentive to change its laws to end that activity. Thus, an onshore jurisdiction acting to preserve its interests easily may destroy offshore arbitrage opportunities.

This was the case with respect to the Antilles' financial subsidiary business in the 1970s and 1980s. The use of Antilles N.V. vehicles to acquire U.S. real estate and other investments, and to give U.S. firms access to the Eurobond market, depended on U.S. and Antilles laws and regulations. These transactions made the Antilles' offshore financial sector successful, but they also increased foreign investment in U.S. debt. At least initially, the benefit to the U.S. was greater than the offsetting foregone withholding tax revenue. Over time, however, lost tax revenue grew dramatically as ever-larger numbers of firms in other jurisdictions began to create Antilles entities in order to benefit from the Antilles' favorable tax treaty with the United States. It is not particularly surprising that revenue concerns predominated in the early 1980 s since the negotiation of tax treaties in the United States was, at that time, under the effective control of the Department of the Treasury, rather than the State Department. ${ }^{331}$ Moreover, as the benefits of the U.S.-Antilles tax treaty were increasingly extended to persons not physically resident in the Antilles, the U.S.

330. See Barbara E. Brown \& John C. Ogden, Coral Bleaching, 268 SCl. AM. $64-70$ (Jan. 1993) (describing risks to coral reefs).

331. 1983 Tax Evasion Hearings, supra note 4, at 16 (statement of William J. Anderson, Director, General Government Division, General Accounting Office) (State Department "delegated" authority to negotiate tax treaties to Treasury). 
Treasury worried that its "accidentally generous" treaty ${ }^{332}$ was undermining broader policy goals by reducing the efficacy of a reduction in the withholding tax used by Treasury to incentivize third countries to enter into tax information agreements.

The challenges of change for the Antilles approached from another direction, as well. Beginning in the late $1970 \mathrm{~s}^{333}$ and continuing to the present, onshore jurisdictions have expressed a growing concern about the use of offshore financial centers to shield illicit activity. ${ }^{334}$ In the late 1970s, there was a fear among developed countries that the growing volume of transactions in the Antilles would attract the attention of those who saw ways to use the entities available there - together with the island's use of bearer shares and bonds - to shield unsavory transactions from law enforcement scrutiny. The opposition to financial intermediation thus grew to include law enforcement and tax authorities around the world that were focused on the illegal uses of offshore financial centers. ${ }^{335}$ The Organization for Economic Cooperation and Development (OECD), the European Union (EU), and some onshore jurisdictions such as France and Germany exerted and have continued to make significant efforts to restrict opportunities for offshore financial centers to engage in financial intermediation. ${ }^{336}$ Reasonable people can differ over whether offshore financial centers in the 1970s (or today) primarily produced tax avoidance or tax evasion, or over whether they led to capital inflows or money laundering. However, regardless of the motive, as the offshore world grew in significance, it began to be perceived as a threat by onshore interests that had previously ignored it. Greater scrutiny of offshore financial centers and the possibility of resulting changes in legal regimes necessarily puts a premium on diversification and responsiveness to change, which we discuss in the following section.

\section{The Imperative of Legislative Agility}

The third proposition we take from the Antilles' saga is that to survive in the midst of change requires legislative agility. The Antilles' economic history vividly

332. In the case of the Antilles, its tax treaty with the United States just happened to have the favorable withholding tax provision that made the Dutch sandwich possible while other jurisdictions' treaties did not. See 1983 Tax Evasion Hearings, supra note 4, at 205 (statement of Marshall J. Langer, Attorney of Counsel, Shutts \& Bowen) ("It is largely by accident that the U.K. overseas treaty doesn"t work for this purpose while the Antilles treaty does. The 1945 U.K. treaty contained an interest article almost identical to the one in the Antilles treaty. However, the notes extending the 1945 U.K. treaty to overseas territories deleted the interest article for most of the U.K. territories to which the treaty was extended.").

333. Belotsky, supra note 253 , at 45 ("Tax havens have existed for some time but did not begin to present themselves as a major loss of revenue problem for the United States until 1970.").

334. Stop Tax Haven Abuse Act, H.R. 1265, 111th Cong. (2009) (the purpose of this act is "[t]o restrict the use of offshore tax havens and abusive tax shelters to inappropriately avoid Federal taxation ..."); Stop Tax Haven Abuse Act, S. 506, 111th Cong. (2009); Lynnley Browning, A Swiss Bank is Set to Open its Secret Files, N.Y. TIMES, Feb. 19, 2009, at A1 ("UBS, the largest bank in Switzerland, agreed ... to divulge the names of well-heeled Americans whom [federal prosecutors] suspect of using offshore accounts at the bank to evade taxes.").

335. See Boise, supra note 14 (discussing the opposition).

336. See Rawi Abdelal, Capital Rules: The Construction of Global Finance 3-4 (2007) (summarizing critical role of French policy makers from the left because "[s]ocialists came to believe that capital controls did not work to prevent the rich and well-connected from spiriting their funds out of the country, but that they worked all too well to lock up the bank accounts of their working- and middle-class constituents and voters"). 
portrays the types of challenges that small open economies routinely confront. From its vulnerability to Venezuelan tariffs in the nineteenth-century, to the boom and bust of the refinery years in the mid-twentieth century, the Antilles' economy has been buffeted repeatedly by events outside its control. The collapse of the islands' financial sector in the 1980 s only illustrates the speed with which a particular form of offshore financial intermediation can be dismantled by onshore jurisdictions. Although the Antilles' finance subsidiary regime survived for more than two decades, it unraveled within a relatively short period of time. Thus, the history of the Antilles provides a cautionary tale of the need for flexibility and agility in responding to changes in the economic environment and in the legal regimes in both competing and onshore jurisdictions.

Legislative agility as it relates to the success of offshore financial centers means at least three things. First, although some offshore jurisdictions initially may achieve success by virtue of fortuitous events occurring elsewhere, ${ }^{337}$ most have exercised legislative powers to lay the groundwork that either created or enhanced legal differences capable of providing opportunities for arbitrage. Success in this regard generally is the product of private- or public-sector entrepreneurial visionaries and a concerned political leadership willing to listen to the ideas of these visionaries and implement them through often novel and creative laws. ${ }^{338}$ In the case of the Antilles, Anton Smeets saw an opportunity in the relocation of the statutory seats of Dutch companies during wartime. ${ }^{339}$ Of course, the market has changed considerably since then; onshore jurisdictions now view offshore financial centers with deep suspicion ${ }^{340}$ and are less willing to enter into tax treaties and other arrangements that would facilitate offshore financial intermediation. Nonetheless, an offshore financial sector is unlikely to be created today absent a somewhat agile and creative legislature.

Second, the same legislative agility that creates offshore intermediation opportunities also must be exercised when business and political changes threaten the viability of those opportunities. Following liberation of the Netherlands from German occupation, sympathetic and forward-looking legislators sagely followed Smeets's advice in enacting the first-of-its-kind ring-fenced tax regime, which enticed many Dutch companies to stay in the Antilles. ${ }^{341}$ Similar examples occur in the histories of other offshore jurisdictions. ${ }^{342}$

Law enforcement and national security concerns have led to pressures on offshore financial centers that were unimaginable forty years ago. Offshore financial centers have been required to adapt on a wide range of fronts, from accepting tax information agreements ${ }^{343}$ with countries like the United States, to coping with the

337. See supra text accompanying note 333-336.

338. See Richard Hall, The Attractiveness of the Cayman Islands to Asian Companies, CAYMAN FIN. REV., July 2009, available at http:/www.compasscayman.com/cfr/cfr.aspx?id=1886\&terms=richard+hall (listing the appeal of the Cayman Islands' law for Asian Companies).

339. Dr. Camille Stoll-Davey, Presentation, March 2008 (on file with author).

340. Interview, Behr, HBM Group, supra note 103.

341. Id.

342. See Boise, supra note 14 (describing other offshore jurisdictions, including the Cayman Islands).

343. A tax information sharing agreement may be included within a tax treaty to facilitate exchanges of relevant information necessary to carry out the provisions of the treaty. U.S. TREAS. DEP'T., U.S. Model Income Tax Convention (1996); Reuven S. AVI-Yonah, U.S. InTERnational TaXation: CASES AND MATERIALS 351 (2002). Exchange of information helps countries prevent fiscal evasion, one of the purposes of tax treaties. AVI-YONAH, at 354. 
EU's savings directive. ${ }^{344}$ Moreover, tax authorities are paying closer attention to structures designed to minimize (and sometimes evade) domestic income taxes. As a result, campaigns like the OECD's harmful tax competition initiative have taken their toll both by raising the cost of doing business in offshore financial centers and by making the reputation costs of offshore financial transactions higher. ${ }^{345}$ Indeed, rather than the leniency in tax rulings from the Antilles authorities that might have dominated the calculation in the past, the extra scrutiny from onshore tax authorities that use an offshore structure could be determinative today. Effective responses to these challenges call for an adaptive regime.

Finally, it is crucial that an offshore jurisdiction be able to do each of the foregoing things rapidly. Today, innovations move much more quickly among offshore jurisdictions (and between offshore and onshore jurisdictions, as the advances in the onshore captive insurance industry in the United States demonstrate). Jurisdictions seeking to develop offshore financial sectors frequently have copied innovative laws (sometimes word-for-word) from other jurisdictions, even across the civil law-common law divide. For example, in the 1960 s the Cayman Islands copied the successful Bahamian and Bermudian offshore centers' strategies. ${ }^{346}$ Likewise, in the private foundation market, the Antilles' current competitors include the Bahamas and Nevis, both of which are English-language, common-law jurisdictions that have passed similar, private foundation laws. ${ }^{347}$ The difference between the Bahamas-Cayman Islands competition in the 1960s and early 1970s and today's competitive market for private foundations is that copying occurs much more quickly today because of the expansion of worldwide communication capabilities. Offshore financial centers that do not formulate and implement responses to competitive challenges with sufficient alacrity will lose nascent financial intermediation opportunities.

In sum, legislative flexibility, as we define it, requires that a jurisdiction create the legal conditions for arbitrage, react effectively to changes affecting those legal conditions, and act in these matters with speed and certainty. One Antilles attorney used a particularly colorful metaphor in discussing how the island had to adapt to changes in U.S. and EU tax and regulatory policies, "If you stand in the ring with

344. The EU's savings tax directive required EU member states, as of July 2005, to either provide information on interest payments made by paying agents established in their jurisdictions to individuals resident in other member states, or to levy a withholding tax on such interest payments and transfer seventy-five percent of the tax revenue to the investor's state of residence. See Council Directive 2003/48/EC, On Taxation of Savings Income in the farm of Interest Payments, 2003 O.J. (L 157) 38-48. The directive contravened the strong secrecy traditions of many OFCs.

345. The classic example of a reputation cost constraint was the abortive effort by Stanley Works to avoid U.S. taxation of its foreign-source income through a corporate "inversion" transaction that would have resulted in it becoming a subsidiary of a newly incorporated Bermuda parent. See Craig M. Boise and James C. Koenig, Practical and Policy Considerations in Corporate Inversions, CORP. BUS. TAX'N Monthly 3 (Sept. 2002); Stanley Works Drops Move to Bermuda, L.A. Times, Aug. 2, 2002, at C-3; Dan Ackman, Stanley Works Stays Home, ForBES, Aug. 2002 (estimating annual tax savings of moving to Bermuda at $\$ 30$ million).

346. MiChael CRaton, Founded Upon the SEAS; A History of the Cayman ISLANDS AND THEIR PEOPLE 353 (2003).

347. Foundations Act, No. 8 (2003) (St. Kitts \& Nevis), available at http://www.fidesco.com/downloads/skn/Foundations\%20Act,\%202003.pdf; Foundations Act, No. 23 (2004) (Bah.), available at http://laws.bahamas.gov.bs/annuals/No23of2004style.html. 
Mike Tyson and get hit, you are dead. You have to dodge and hope he gets tired out." 348

\section{Constitutional Concerns}

The fourth proposition that may be drawn from the Antilles' experience is that a jurisdiction's capacity with respect to each of the first three propositions will be affected by its own constitution. By "constitution," we do not refer to a particular founding document such as the U.S. Constitution, although such a "capital C" constitution certainly may be relevant to our inquiry. Rather, we refer to the geopolitical arrangement from which a particular jurisdiction derives its sovereignty and the legal structures it employs internally. It is this "small c" constitution that will affect the ability of a jurisdiction to identify opportunities that result from the persistent differences between its legal regime and those of other jurisdictions, recognize and anticipate its vulnerability to changes taking place elsewhere, and respond flexibly to legal and business changes in competing offshore and onshore jurisdictions.

There are at least three "constitutional concerns" that affect the success of an offshore jurisdiction's financial intermediation sector. ${ }^{349}$ First, an offshore jurisdiction must have legitimacy as a sovereign. Firms contemplating doing business in an offshore center like the Antilles must view that jurisdiction as having the authority to make laws in those areas that touch anticipated transactions. More importantly, those laws must be respected by onshore jurisdictions. In this regard, most offshore jurisdictions are fortunate to have been former colonies of longestablished onshore jurisdictions. Consequently, both the offshore jurisdiction's legitimacy and that of its laws tend to be linked to a greater or lesser degree to an onshore jurisdiction regardless of the nature of the ongoing relationship between the onshore jurisdiction with its former colony. A former British colony, for example, benefits from a stature within the global community that is largely based on the collective recollections of a historical relationship, even if current links to the U.K. are attenuated.

Second, in addition to geopolitical legitimacy, the successful offshore jurisdiction must offer a high degree of political and economic stability. Any jurisdiction's desirability as an investment destination, whether it is an offshore financial center or otherwise, bears a direct relationship to its stability. In the case of the Antilles, as we described in Part I, the Kingdom Treaty provided a constitutional structure that excelled in this regard, as evidenced by the Antilles' lack of interest in obtaining independence from the Dutch Kingdom. The Antilles' continued association with the Kingdom, its use of a well-respected Dutch court as the final court of appeal, the Kingdom's guarantee of the rule of law, and other features of its relationship with the Netherlands permitted the Antilles to make a credible commitment to investors that their business structures would be protected. Even in the years immediately following the May 1969 riots that profoundly shook Dutch confidence in the Antilles' political leadership, business confidence continued and

348. Interview, Elias, United Trust Co., supra note 13.

349. For a fuller treatment of issues of sovereignty in offshore financial centers, see Boise \& Morriss, Offshore, supra note 14. 
the offshore sector grew significantly. ${ }^{350}$ This was largely because of the Dutch commitment to ensuring political and legal stability in the islands. ${ }^{351}$

By contrast, however, the Bahamas failed to reassure investors that the transition from rule by the pre-independence "Bay Street Boys" clique to Lynden Pindling's post-independence nationalist majority government would not lead to wholesale renegotiation of the terms under which offshore activity occurred in the Bahamas. ${ }^{352}$ This failure prompted large-scale capital flight from the Bahamas to Cayman. $^{353}$ In effect, jurisdictions must offer investors a bond for their future performance. One effective means of doing so is a constitutional structure that limits the ability to renege. However, combining that with sufficient flexibility to respond to changes is a tricky balancing act.

Third, and most importantly, a successful offshore jurisdiction's geopolitical circumstances must not unduly hinder or constrain its ability to exercise flexibility in responding to the inevitable challenge of changes in business conditions and legal regimes around the globe that could threaten its financial sector.

In sum, a jurisdiction described by our theory possesses sufficient legislative agility within a largely unrestrictive constitutional framework to permit it to find the persistent exploitable differences among legal regimes even as the jurisdiction's economic survival is challenged by external change. We assert that such a regime possesses plasticity rather than merely flexibility because the former suggests retention of the essence of a secure legal regime even as that regime reshapes itself in response to change. A jurisdiction must be able to adapt while offering sufficient guarantees that its flexibility in response to events does not include the ability to renege on the regulatory bargain it has offered investors to entice them to use it as the location for financial intermediation or arbitrage.

\section{B. The Netherlands Antilles in the Aftermath of Treaty Repeal}

Having articulated a theory of regime plasticity in offshore financial intermediation, we next turn to an assessment of the Netherlands Antilles' experience in light of that theory. Although helping to inform our theory of regime plasticity, the Antilles has not successfully modeled each of the four elements of that theory. The existence of the U.S.-Netherlands Antilles tax treaty is, of course, a clear example of the first element of our theory-the persistence of differences in legal regimes that may lead to arbitrage opportunities. Moreover, the loss of the treaty is just the sort of challenge presented by a change in legal regimes that offshore jurisdictions inevitably must confront under the second postulate of our theory. We turn our focus in this section to the third and fourth elements of our theory-namely, the Antilles' exercise of legislative agility in responding to the challenge of change, and the ways in which that agility might have been constrained by constitutional concerns.

350. LANGER, supra note 9, at 113; BANK VAN DE NEDERLANDSE ANTILLEN, supra note 159, at 8-9.

351. LANGER, supra note 9 , at 113.

352. Morriss \& Boise, supra note 193, at 25.

353. Id. at 23. 


\section{The Post-Treaty Antilles and Legislative Flexibility}

It is unfortunate that despite its remarkable success in the two decades leading up to the U.S. cancellation of its tax treaty the Antilles financial sector was largely a failure in the decade that followed. The Antilles failed to anticipate and effectively react to the threat of treaty repeal, despite clear signs of the potential for substantial change to the differences in legal rules that permitted the offshore financial subsidiary business to thrive. The result has been a financial sector that, with a few exceptions, has remained stagnant.

This is not to say that following treaty repeal the Antilles failed to identify any new financial sector opportunities. The Antilles rather quickly attempted to transform the now-defunct Antilles sandwich into a "Dutch sandwich" structure that would appeal to foreign (but non-U.S.) shareholders in Dutch companies. Ordinarily, a dividend paid by a Dutch company to foreign shareholders would be subject to a twenty-five percent Dutch profits tax. By contrast, under the Netherlands-Netherlands Antilles tax treaty, a dividend payment from a Dutch company to a Netherlands Antilles holding company is subject to an eight and threetenths percent withholding tax. ${ }^{3.4}$ Thus, substantial Dutch tax could be avoided by shareholders of Dutch companies who formed Antilles holding companies through which to route dividend payments. This strategy initially was quite successful, making the Antilles the jurisdiction of choice for shifting dividend payments out of Europe. $^{355}$

The Antilles also made efforts to expand its financial sector beyond holding company structures. In the 1980 s, several influential individuals in the insurance industry urged the Antilles to create a captive insurance sector. ${ }^{3.6}$ Their initial efforts led to the establishment of sixty to seventy captive insurance companies by the late 1980s. ${ }^{357}$ However, unlike Bermuda and Cayman, ${ }^{358}$ the Antilles failed to create any specialized legal or regulatory structures for captive insurers and eventually lost momentum compared to those jurisdictions. Worse, certain provisions of Antilles law affirmatively discouraged the captive insurance industry. One such provision severely limited the number of insurance companies that any one individual could manage, even though the minimal activity involved in such management would have permitted insurance managers to accept additional captive clients and made the sector economically viable. ${ }^{359}$ Today, the Antilles are home to fewer than twenty

354. Interview, Paassen-Delsol, Paassen Delsol, supra note 71. The revenue from this withholding tax is directly passed on to the Antilles government by the Dutch. Id.

355. Interview, Behr, HBM Group, supra note 103.

356. See Interview, Elias, United Trust Co., supra note 13 (establishing that the Antilles created a small, captive insurance sector after 1988).

357. Bank VAN DE NEDERLANDSE ANTILlEN, FinANCIAL INFORMATION Guide 38 (1990). By contrast, the Cayman Islands, which began to aggressively develop its captive insurance industry in the 1980s, had 777 captives at the end of 2008. See CAYMAN ISLANDS MONETARY AUTHORITY, LIST OF INSURANCE COMPANIES BY INSURANCE MANAGER, July 15, 2009, available at http://www.cimoney.com.ky/WorkArea/linkit.aspx?LinkIdentifier=id\&ItemID=976 (providing list of captive insurance companies); Dennis J. Block, Nancy E. Barton \& Stephen A. Radin, Indemnification and Insurance of Corporate Officials 83, in DIRECTORS' AND OFFICERS' LIABILITY INSURANCE 1991, at 9, 83 (1991) ("Until the mid-1980s, captive insurance subsidiaries were often domiciled in offshore places such as Bermuda or the Cayman Islands, which are free from U.S. insurance regulations.").

358. See 1983 Tax Evasion Hearing, supra note 4, at 205 (statement of Marshall J. Langer. Attorney of Counsel, Shutts \& Bowen).

359. Interview with Edgar Nunes, Atlas Ins. Co. \& Felipe Croes, Managing Director, Irma Insurance, 
captive insurers. ${ }^{360}$ The failure to successfully launch a captive insurance industry appears to be a direct result of a lack of legislative agility. The Antilles also did not capitalize on key niche opportunities in the captive insurance market that might have been fruitful despite the general dominance of Bermuda and Cayman in the sector, and as a result, other jurisdictions stepped in. For example, Barbados made an aggressive bid for Canadian captive insurance business; now roughly 195 of that jurisdiction's 212 captives insure Canadian risks. ${ }^{361}$

Apart from the Dutch sandwich and the unsuccessful attempt to establish a captive insurance sector, it was nearly a decade after the cancellation of the U.S. $\operatorname{tax}$ treaty before Antilles passed any significant legislation to create exploitable legal differences that would resuscitate its offshore financial sector. This failure to adapt, of course, is inconsistent with our contention that, under the third prong of our theory, offshore jurisdictions must respond ever more rapidly to external changes that threaten their financial sectors.

\section{The Post-Treaty Antilles and Constitutional Concerns}

The Antilles' attempts to re-tool following the end of the finance subsidiary era have been hampered in important ways by constitutional concerns-the fourth element of our theory of regime plasticity. This element requires that an offshore jurisdiction have legitimacy as a sovereign, offer a high degree of political and economic stability, and not be hindered or constrained by its constitutional arrangements in responding to the inevitable challenge of changes in legal regimes around the globe that could threaten its financial sector. It is the final element of this formula that has proved problematic to the Antilles and prevented it from rebounding substantially from the blow of tax treaty repeal. This inability to recover is the result of several weaknesses in the Antilles constitutional arrangements.

The first weakness is the Kingdom Charter itself, which does not confer on the Antilles as much independence as possessed by British Overseas Territories like the Cayman Islands, British Crown Dependencies like the Isle of Man, and independent Commonwealth nations like Barbados. ${ }^{362}$ Britain's relationship with its Crown Dependencies and Overseas Territories has provided a model, at least until recently, for a governmental arrangement that provides enough autonomy to permit creation of the legal differences necessary for an offshore industry to flourish, while providing a check on the local autonomy sufficient to reassure investors of the jurisdiction's political stability. ${ }^{363}$ Even the French system, which is based on integrating its territories, rather than providing them a significant measure of autonomy, and which

in Curaçao, Neth. Antilles (May 22, 2008) [hereinafter Interview, Nunes \& Croes]. The government also failed to address the lack of sufficient local insurance industry staff, leading those involved in attempting to set up captives to complain that the government has not invested sufficiently in the enterprise. Id.

360. Id.

361. Id.

362. Compare U.S. Dep't. of State, Background Note: Netherlands Antilles (2009), available at http://www.state.gov/r/pa/ei/bgn/22528.htm (describing the Netherlands Antilles as enjoying "semiautonomy on most internal matters") with Interview with Vaughan Carter (March 13, 2006) [hereinafter Interview, Carter] (describing the extent of the Cayman's autonomy from the UK).

363. Several events in the last few years, including the growing influence of the EU and efforts by the OECD and others to restrict the activities of tax havens have called into question the continuing utility of this model. See Interview, Carter, supra note 362 (describing tensions in the Cayman-UK relationship). 
has largely precluded them from developing financial intermediation sectors, has been seen by Antilleans as preferable to the Dutch Charter arrangement. ${ }^{364}$

Although the virtues of the British, and particularly, the French systems may have been overstated, the Kingdom Charter clearly has had its shortcomings. In particular, it confers both too much and too little independence on the Antilles. On the one hand, the Antilles are sufficiently independent of the Kingdom's jurisdiction that they have been able to pass tax and other legislation that has permitted the development and maintenance of an offshore financial sector. On the other hand, the Antilles connection with the Netherlands is in some respects cumbersome enough that other important steps have been either slowed or halted altogether. The structure of the Charter, which provides each entity with a veto over revisions, allows change to be blocked. ${ }^{365}$ At times this has advantaged Curaçao, but the advantage of such a blocking veto shifts between the Netherlands and the Caribbean, depending on which country seeks a change. With respect to adapting to changes in the offshore environment, the Dutch veto has been a disadvantage for the Antilles.

The Antilles also are independent enough within the Kingdom to be viewed as competitors for financial services business as the Dutch increasingly have emphasized that sector since the 1990s. ${ }^{366}$ Hence, although in some cases the Kingdom's failure to act promptly on matters affecting the Antilles simply may be bureaucratic sluggishness, in others it may be motivated, at best, by negligent disregard of Antilles' interests, or at worst, by a desire to stifle competition from the Antilles. An example of the former is the Antilles' efforts to promote the Dutch sandwich. Although the new structure was briefly successful, offering an eight and three tenths percent tax rate on dividends paid by Dutch companies through Antilles holding companies, the Netherlands soon negotiated new tax treaties with Cyprus, Luxembourg, and Malta that provided for a zero withholding tax rate on dividends paid by Dutch companies to holding companies in those jurisdictions. Thus, the Netherlands not only negotiated away the Antilles' tactical advantage in treaties with other jurisdictions, it also has been unwilling to renegotiate its tax treaty with the Antilles to reduce the eight and three-tenths percent tax rate to the zero rate it was willing to offer other jurisdictions that lacked the historical and political relationship shared by the Netherlands and the Antilles. ${ }^{367}$

A major problem for the Antilles in developing a revitalized financial services sector has been the Antilles' lack of tax treaties with important markets like the U.S., ${ }^{368}$ and the uncompetitive terms of the Netherlands-Netherlands Antilles tax treaty (which imposed the eight and three-tenths percent withholding tax). ${ }^{369}$ For

364. See Robert Aldrich \& John CONnell, France's OVERseas Frontier 76 (1992) (describing close legal integration of overseas territories with metropolitan France following World War II).

365. STATUUT VOOR HET KONINKRIJK DER NEDERLANDEN [STATUUT NED] [Constitution], art. 12 (Neth.).

366. SLUYTERMAN, supra note 1, at 241 (describing how a "new realism" in the Netherlands about economy led to a turn to service sector in 1990 s after focus on manufacturing in 1970 s and 1980s); Interview, Elias, United Trust Co., supra note 13 (noting competition for management company (trust company) business). The Netherlands has historically had an extensive network of tax treaties, including "agreements with most industrial nations and many developing countries." Belotsky, supra note 253, at 90-91.

367. Interview, Behr, HBM Group, supra note 103.

368. Interview, Paassen-Delsol, Paassen Delsol, supra note 71.

369. Interview, Behr, HBM Group, supra note 103. 
example, Barbados, which could serve as a model for a tax-treaty-network jurisdiction, has sixteen tax treaties, including treaties with the United States, China, and the Netherlands, and nine investment treaties, ${ }^{370}$ and aggressively seeks to negotiate new ones. ${ }^{371}$ Although the Antilles was extremely anxious to negotiate a new U.S. treaty after the old treaty was canceled, the Netherlands controlled the critical Kingdom institutions that approved treaties. ${ }^{372}$ Thus, more than twenty years later, the Antilles is still without a new treaty with the United States. Similar footdragging by the Kingdom occurred when the European Union issued its savings tax directive $^{373}$ and the Antilles sought a new treaty with the Netherlands to enable it to compete with other EU jurisdictions. ${ }^{374}$

Not only did the Netherlands compete with the Antilles for some business, but the Netherlands had important interests in conforming to European Union mandates and assisting in OECD measures that the Antilles did not share. As Professors Oostindie and Klinkers conclude, "[w]here the Netherlands had different priorities to those of the Antillean and Aruban governments, it was generally prepared to act upon them, regardless of the views of its Caribbean partners." 375 For example, the Dutch complied with EU demands that it close the "Antillean route" by which sugar and rice were imported into the Antilles and Aruba and lightly processed and then re-exported to the EU. ${ }^{376}$ This led the Antilles to "[t]he painful realization that Europe mattered far more to The Hague than the 'Dutch' Caribbean" did. ${ }^{377}$ Thus, notwithstanding that the Kingdom Charter gives the Antilles a strong position vis-avis the Dutch, over the last decade and a half the relationship between the Netherlands and the Antilles has been characterized by "constant political bickering, sparked by the Dutch.",378

370. See list at International Business Unit, Ministry of Foreign Affairs, Foreign Trade \& International Business, Government of Barbados, Bilateral Investment Treaties and Double Taxation Agreements, available at http://www.investbarbados.org/dtas.php.

371. Interview with Ben Arrindell, Ernst \& Young, Barbados, May 2007.

372. Ministry of Foreign Affairs and Foreign Trade of Barbados, Treaties, http://www.foreign.gov.bb/pageselect.cfm (last visited Nov. 19, 2009) (select "Treaties" on the left-side menu; then select "Treaties List" in the left-side menu; then select "Financial Services" in the drop-down menu and click "Go") (listing various treaties totaling sixteen related to tax and nine related to investment).

373. See also Press Release, Ministry of Foreign Affairs and Foreign Trade of Barbados, Barbados Signs Double Taxation Agreement with the Netherlands (December 2006), available at http://www.foreign.gov.bb/Userfiles/File/Taxation\%20with\%20Netherlands.pdf, (quoting the deputy prime minister, "our security lies in having a multiplicity of such agreements ..." and noting a forthcoming agreement with Mexico and a recent agreement with Austria).

374. See StatuUt VOOR HET KONINKRIJK DER NEDERLANDEN [STATUUT Ned] [Constitution] art. 26 (Neth.) (stating that the "...Government of the Kingdom shall assist in the conclusion of such an agreement, unless this would be inconsistent with the Country's ties with the Kingdom"); see also Hurst Hannum and Richard B. Lillich, The Concept of Autonomy in International Law, 74 AM. J. INT'L L. 858, 875 (1980) (discussing the relatively high degree of autonomy cnjoyed by the Netherlands Antilles in reaching international financial agreements, subject to the limitation in Article 26 of the Charter of the Kingdom of the Netherlands).

375. OOSTINDIE \& KLINKERS, supra note 6 , at 134 . This also was apparent at the "Futures Conference" held by the Kingdom in March 1993, at which it became evident that the Antillean and Aruban delegations had different views of the need for Kingdom involvement in governance in the Caribbean than did the Dutch. Id. at 136-37.

376. Id. at 14445 .

377. Id. at 145 .

378. Id. at 219. As Curaçaoan writer Boeli van Leeuwen put it, "every time the Dutch laid out the game of chess, their Antillean and Aruban opponents hurried to pull out their game of dominoes instead." 
Yet another source of tension between the Netherlands and the Antilles was that the Netherlands became more assertive about its views on governance issues in the Antilles as it began to accept that the islands would not agree to independence. ${ }^{379}$ This led to a renewal of Dutch interest and involvement in Antilles governance in the 1990 s and 2000s. ${ }^{380}$ Indeed, the Kingdom (i.e., Dutch) takeover via an Order in Council of the Sint Maarten government because of serious governance problems from February 1993 to September 1994, with continuing involvement until March 1996, made clear that the Dutch were now willing to override local autonomy when they felt it necessary. ${ }^{381}$ The Dutch also were unhappy with the both the level of Antillean migration to the Netherlands and the amount of aid the Dutch provided to the Antilles. ${ }^{382}$ Difficulties like these in its relationship with the Netherlands hindered the Antilles' reinvention of the financial sector in the 1990s and 2000s. All of this suggests that a successful offshore jurisdiction must have more sovereigntyat least de facto, if not de jure - than the Antilles had in the 1980s and 1990s in order to nimbly adapt to the increasing pace of change in the financial industry.

The Antilles also have been hampered by their position within the EU. The European Union's political structure, to which the Antilles' fortunes are tied through their status within the Kingdom, does not give the Antilles sufficient autonomy to play a role within the EU analogous to the role the state of Delaware plays within the United States. Ironically, the Antilles' autonomy is too great to permit it to participate fully in the Dutch membership of the European Union. By contrast, the French Caribbean territories receive considerable development assistance from the EU by virtue of the fact that they have minimal autonomy from France. ${ }^{383}$

Finally, in addition to the constraints imposed by the political structure of the Kingdom, the Antilles must contend with an internal structural issue. The overall economy of the Antilles is large enough that its offshore financial sector does not occupy the predominant position within the economy that a financial sector often does in smaller offshore jurisdictions. As a result, the Antilles financial sector does not receive the same focused attention from government policy-makers as the Cayman financial sector (or even that of Delaware, in the United States). ${ }^{384}$ The lack

Id.

379. OOSTINDIE, supra note 21 , at 15 ("Having accepted this state of affairs [regarding refusal to leave] by 1990 , the Netherlands have since hammered home the need for the Antillean and Aruban authorities to model their policies on metropolitan standards ....").

380. OOSTINDIE \& KLINKERS, supra note 6, at 131-32. See also id. at 221 ("[S]ince the beginning of the 1990s, informal Dutch involvement with the Antillean and Aruban governments has increased considerably.").

381. Id. at 134-35. Unfortunately, this involvement was insufficient to head off a "severe crisis in the Antillean administration economics and indeed society . . at the end of the twentieth century ..." Id. at 120. Relations worsened in 2002, when the outgoing Secretary of State "published an article in a leading Dutch newspaper" that expressed his "frustrations and clear warnings" about Antillean affairs. Id. at 15051 .

382. Id. at 148-49. In 2002, 115,000 Curazoleños lived in the Netherlands compared to 130,000 who actually lived on the island. $I d$. at 149 . Per capita Dutch aid to the Antilles quadrupled from 1976 to the late 1990s. OOSTINDIE \& KLINKERS, supra note 6, at 164 . This has led to a growing Dutch insistence that aid transfers must eventually stop being necessary, although some argue that the total amount per Dutch taxpayer is negligible and that the Dutch question is primarily one of efficacy. Id. at 164-66.

383. In 2001, for example, French territories received between $€ 2,900$ and $€ 3,800$ per capita total transfers. Id at 173. See also Fred Constant, The French Antilles in the 1990s: Between European Unification and Political Territorialism, in ISLANDS AT THE CROSSROADS: POLITICS IN THE NONINDEPENDENT CARIBBEAN (Aaron Gamaliel Ramos \& Angel Israel Rivera eds., 2001) at 80, 82-85.

384. For example, a 1975 survey of the Antilles' suitability as an offshore jurisdiction noted that the 
of such attention has slowed the Antilles government's reaction to changes in the industry and made it difficult to compete with more focused jurisdictions.

\section{LESSONS FOR THE FUTURE OF OFFSHORE FINANCIAL INTERMEDIATION}

Analysis of the Antilles' history under our theory of regime flexibility suggests some conclusions on both the prospects for the Antilles offshore financial sector and the future of the global offshore financial sector as a whole. We discuss these in the following sections.

\section{A. The Prospects for the Antilles}

Notwithstanding relative legislative paralysis in the years immediately following the repeal of the U.S.-Netherlands Antilles tax treaty, the Antilles eventually began to respond in ways suggestive of the imperative of legislative agility - the third element of our theory of regime plasticity. That response began in 1994 with passage of a new law that allowed "international insurance companies" that did not operate locally. ${ }^{385}$ Unfortunately, the legislation came long after similar laws had been established in Bermuda and Cayman. ${ }^{386}$ Today, the Antilles is home to fewer than 20 captive insurers, and growth in the sector is flat. ${ }^{387}$ Key niche opportunities in the captive insurance market that might have been fruitful, despite the general dominance of Bermuda and Cayman in the sector, have been seized by other jurisdictions. ${ }^{388}$

corporate law had not been changed in almost 40 years and was not updated in 1970 when the Dutch corporation law was "materially changed." LANGER, supra note 9, at 189. Compare Delaware's efforts to maintain its corporate statute, described here:

An "advanced" and "flexible" corporate statute is one reason for Delaware's preeminence. Delaware adopted its first modern corporation statute in 1899 and since that time the Delaware legislature has amended the statute hundreds of times. In reality, however, the Delaware Bar Association's Section on General Corporation Law is responsible for revising the General Corporation Law. Members of the Section and its subcommittees carefully study and make suggestions concerning proposed amendments to the Delaware General Corporation Law. The General Assembly, in most cases, adopts the amendments recommended by the Section. In this fashion, Delaware's General Corporation Law is continually amended by the Bar Section on General Corporation Law and the General Assembly. The "close working relationship" between the Delaware General Assembly and the corporate bar works to ensure a swift response to corporate needs in the form of a flexible statute. This collaboration also reveals the significant degree of private and public interaction in the corporate lawmaking process.

Omari Scott Simmons, Branding the Small Wonder: Delaware's Dominance and the Market for Corporate Law, 42 U. RICH. L. REV. 1129, 1155-57 (2008) (citations omitted). On Cayman's adaptability, see Alan Markoff, Part 2: The Freewheeling 1970s: The Cayman Islands: From Obscurity to Offshore Giant, CAYMAN FIN. REV., July 15, 2009, available at http://www.compasscayman.com/cfr/cfr.aspx?id=713.

385. Interview, Nunes \& Croes, supra note 359.

386. See, e.g., Insurance Act, 1978, tit. 17, item 49 (Berm.); Insurance Law, 1979, law 24 (Cayman Is.).

387. Interview, Nunes \& Croes, supra note 359.

388. For example, Barbados made an aggressive bid for Canadian captive insurance business; now roughly 195 of Barbados's 212 captives insure Canadian risks. Id. 
The Antilles captive insurance legislation was followed by the 1998 introduction of an asset-protecting "private foundation" entity modeled on similar entities available in Panama and Liechtenstein. ${ }^{389}$ Private foundations are analogous to common law trusts, but, unlike trusts, they are treated as separate entities. ${ }^{390}$ Once created by its founder, the private foundation has the power to borrow, acquire assets, and make distributions for any purpose stated in its charter, although it cannot conduct business and so must only receive passive income. ${ }^{391}$ Unlike an ordinary civil-law foundation, the private foundation need not have a charitable purpose. ${ }^{392}$ To date, this effort has been more successful than the captive insurance sector. Only twelve private foundations were formed in the first year, but there are now more than 4,000 , with new foundations being formed at a rate of roughly sixty to seventy per month. ${ }^{393}$ Antilles private foundations are most popular in the Benelux countries because of the shared language ${ }^{394}$ and because Antilles private foundations are priced more competitively than those formed in Liechtenstein. ${ }^{395}$

Despite the Antilles relative success with foundations, there remain important obstacles to the expansion of the business. First, the Antilles face competition from common law jurisdictions, like the United States, that recognize trusts rather than foundations. ${ }^{396}$ Such jurisdictions are more attractive to prospective clients from common law jurisdictions, which means that growth in this sector for the Antilles will largely come from civil law jurisdictions. ${ }^{397}$ A second, related obstacle is that while

389. Interview with Eric Passen, ATC Corporate Services, in Curaçao, Neth. Antilles (May 21, 2008) [hereinafter Interview, Passen, ATC Corp. Services]; Interview, Paassen-Delsol, Paassen Delsol, supra note 71. Private foundations are controlled by a board, which functions similarly to a trustee for a trust. The founder can influence the board in several ways: (1) a confidential private agreement can direct the board to act in the interests of particular beneficiaries; (2) the foundation articles can specify the beneficiary; (3) the founder may give the board a non-binding letter of wishes; and (4) a supervisory board, similar to a trust protector, can be appointed to insure the board complies with principal's wishes. Private foundations are generally cheaper to create and administer than are trusts because the fees are based on the work done, not on a percentage of the assets under management as is common with trusts. Id.; Interview with Zuleika S. Lasten, PricewaterhouseCoopers, Curaçao, Neth. Antilles (May 21, 2008).

390. See Glenn C. Rellum, The Private Foundation A BetTer Alternative for the Trust ENTITY (2007), available at http://www.sms-advocaten.com/pdf/spf-short-promotion-document.pdf (providing general information about private foundations in the Netherlands Antilles and description of their operation). Under a common-law trust arrangement, a "grantor" transfers assets to the trust, at which point title to the assets is held by a trustee for the benefit of named (or in some cases, unnamed) beneficiaries. This removes the assets from the estate of the grantor, and hence from the grantor's creditors. AUSTIN WAKEMAN SCOTT ET AL., SCOTT AND ASCHER ON TRUSTS 32-36 (2006) (explaining the general purpose and benefits of a trust). In addition, trusts frequently may be used to avoid estate and other forms of taxation, as well as to avoid probate procedures that otherwise would apply to the transfer of assets upon the grantor's death. Id. at 382-83 (discussing the increased use of trust to avoid more complex will and tax processes upon death of the trustor).

391. Interview, Passen, ATC Corp. Services, supra note 389 (noting that private foundations can make distributions to anyone).

392. Id.

393. Id.

394. Id.

395. Id. One practitioner estimated the cost difference as between US $\$ 5,000$ to $\$ 6,000$. Id .

396. Id. Recently, the Bahamas recently have made an aggressive bid to win foundation business from both civil and common-law jurisdictions by creating a private foundation entity within a common law system. Id. The Bahamian law is so new that many practitioners there are unaware of it. The lack of a track record for the structure in common-law jurisdictions may also hamper the Bahamas in competing in this market. $I d$.

397. Liechtenstein and Panama are the Antilles' biggest competitors for foundation business among jurisdictions having civil law systems. Interview, Passen, ATC Corp. Services, supra note 389. Civil law jurisdictions cannot compete with common law ones directly for trust business because of the lack of 
the IRS has long recognized common-law trusts, American courts have not yet ruled on the tax treatment of foundations. ${ }^{398}$ This uncertainty in tax treatment presents obvious regulatory risks for U.S. persons. Third, Antillean courts recognize forced heirship judgments from other jurisdictions, while the courts of at least one competitor - the Bahamas - do not. ${ }^{399}$ Thus, Bahamian entities may be preferable for potential customers who desire to avoid the operation of the forced heirship statutes common in continental Europe and Latin America. ${ }^{400}$ Finally, the recent use by German and other European tax authorities of data stolen by a bank employee in Liechtenstein identifying founders of private foundations there ${ }^{401}$ may reduce demand for the structure, either by deterring those who intend to commit tax evasion (as opposed to legal avoidance) or by damaging the structure's reputation with reputable customers.

Of greater importance than either of these developments, however, was the passage in December 1999, of sweeping tax and business legislation known as the Nieuw Fiscaal Raamwerk (New Fiscal Framework). ${ }^{402}$ The intent of the legislation was to jumpstart the Antilles' offshore financial services sector and re-establish the jurisdiction's reputation and image as an offshore financial center. The legislation, which took effect on January 1, 2001 (and was prompted by pressure from the OECD's harmful tax competition initiative ${ }^{403}$ ) eliminated the Antilles ring-fenced tax regime and replaced its progressive corporate tax rate schedule with a single thirty percent tax rate for all corporations, both onshore and offshore. ${ }^{40+}$ At the same time,

common law trust jurisprudence. Id.; LANGER, supra note 9, at 188.

398. Interview, Passen, ATC Corp. Services, supra note 389.

399. Id.

400. See Joshua C. Tate, Caregiving and the Case for Testamentary Freedom, 42 U.C. DAVIS L. REV. 129, 138 (2008) ("In most civil law jurisdictions, descendants are generally entitled to a reserved share of the estate unless interested parties show some specific grounds for disinheritance.").

401. Liechtenstein's Shadowy Informant: Tax Whistleblower Sold Data to the US, SPIEGEL ONLINE INT., Feb. 25, 2008, available at http://www.spiegel.de/international/business/0,1518,537640,00.html [hereinafter Liechtenstein's Shadowy Informant]; see Mario A. Mata, Asset Protection Planning for the Family Business Owner, in Estate Planning FOR THE FAMILy Business Owner 617, 737 (2007) ("A foundation in Liechtenstein is a fund or collection of property dedicated to a specific purpose. It is similar in some respects to a common law trust except that the foundation is a separate legal entity that is controlled by its board of directors and governed by the foundation deed which is the document establishing the foundation. The foundation deed, similar to a trust deed, must be filed with the public registry. However, although so filed, the foundation deed is not generally available for public inspection."); Edsel Doran, Private Foundations: A New Option in the Netherlands Antilles, 9 J. INT'L. TAX'N 39 (1998) ("Realizing the potential for developing the foundation even further as an alternative to the trust, and also to the Liechtenstein Anstalt (private establishment), the Netherlands Antilles will introduce the Curaçao private foundation at the beginning of 1998."); Dr. oec Kurt Alig, Liechtenstein Tax System Has Advantages for Holding Companies and Foundations, 8 J. INT'L. TAX'N 318, 7 (1997) ("The foundation is the preferred vehicle for asset management and asset protection purposes; during the last four years, the number of foundations has increased by approximately $25 \%$ and it looks as if this trend will continue.").

402. Nieuw Fiscaal Raamwerk 20 December 2001 PUBLICATIEBLAD [P.B.] 2001 nr. 146 (giving retroactive effect to the amended legislation). PRICE WATERHOUSE COOPERS, CORPORATE TAXES: WORLDWIDE SUMMARIES 2002-2003 582 (2002).

403. See Boise, supra note 14, at 20-21 (discussing the OECD harmful tax competition initiative, calling for the creation of a framework of defensive measures which member countries could choose to enforce against uncooperative tax havens).

404. PRICE WATERHOUSE COOPERS, supra note 402, at 582. 
the Antilles introduced a new form of corporate entity that would permit offshore activity on a tax-exempt basis. ${ }^{405}$

The Framework, although long overdue, represents the sort of legislative agility that is necessary to maintain a successful offshore financial sector. In adopting the New Fiscal Framework, ${ }^{406}$ the Antilles has signaled that it views its financial sector as important. Indeed, the sector produces a small but significant part of the Antilles gross domestic product ${ }^{407}$ and it offers a number of important advantages to foreign investors. These include as sophisticated financial markets workforce, which serves its funds management business, and its reputation as a "cleaner" jurisdiction than some of its main competitors (e.g., Panama). ${ }^{408}$ Moreover, the regulatory structures critical to an offshore financial sector's success are in place, and the Antilles court system also includes a final appeal to the highly respected Supreme Court of the Netherlands in The Hague. ${ }^{409}$ Passage of the New Fiscal Framework also suggests that the Antilles has chosen to model its rebuilt financial sector along the lines of that of Barbados, with a. more-than-nominal corporate income tax rate that makes possible the eventual establishment of a network of tax treaties with onshore jurisdictions. ${ }^{410}$

Of course, the Antilles begins at a significant disadvantage to Barbados, which has both a much more extensive tax treaty network and the sovereignty to move quickly when a treaty opportunity arises. ${ }^{411}$ The Antilles also must compete against jurisdictions like Dubai, with far deeper pockets; ${ }^{412}$ Singapore, with a deeply

405. Id.

406. Nieuw Fiscaal Raamwerk 20 December 2001 P.B. 2001 nr. 146.

407. See Bank VAn de Nederlandse ANTIllen, General EConomic Developments IN THE Netherlands ANTILles, QuARTERLy Bulletin 2008-II, tbl. 3 (2008), available at http://www.centralbank.an/tablepopup.php?file=/qb/20082/index-03.htm.

408. Interview, Passen, ATC Corp. Services, supra note 389. For example, the independent Central Bank has taken on the task of developing a model for anti-money laundering regulation that would apply well beyond financial sector firms, as traditionally defined, to include jewelry stores, car dealerships, and other businesses that frequently are used for money laundering. Interview, Weert \& Gova, Bank van de Nederlandse Antillen, supra note 308.

409. Interview, Elias, United Trust Co., supra note 13.

410. Nieuw Fiscaal Raamwerk 20 December 2001 P.B. 2001 nr. 146. This approach contrasts with that of jurisdictions like the British Virgin Islands or the Cayman Islands which because they have no income taxation, cannot enter into tax treaties with other jurisdictions, and must rely on either a high volume of transactions (e.g., international business corporations in the BVI) or high-value structures (e.g., hedge funds or captive insurance arrangements in the Cayman Islands). See PRICEWATERHOUSE COOPERS, supra note 402, at 582-84. (New Fiscal Framework legislation removed the distinction between onshore and offshore companies, simplified tax rates, and introduced a new corporate form to allow offshore operations on a tax-exempt basis); Grey skies in the Caribbean; Tax and the Cayman Islands, ECONOMIST, May 23, 2009 (Barbados has developed a network of tax treaties), available at http://www.economist.com/world/americas/displaystory.cfm?story_id=E1_TPSDSGST; PRICE WATERHOUSE COOPERS, TAX FACTS AND FIGURES: BARBADOS 20063 (2006) (Barbados corporate tax rates).

411. See Grey skies in the Caribbean, supra note 410 (Barbados has developed a network of tax treaties).

412. See OFFSHORE; The Offshore Puzzle, THE LAWYER, May 5, 2008, at 26 (describing Dubai's efforts to position itself as a rising new offshore financial center, with significant advantages over more established onshore and offshore financial centers). See Bill Maurer, Re-regulating Offshore Finance?, GEOGRAPHY COMPASS 155, 171 (2008) (citing Dubai as an example of a jurisdiction that would not be vulnerable to being bought off by OECD member states for reducing its tax competition effects, in part because of Dubai's extensive network of tax information exchange agreements and double tax treaties, and in part because Dubai itself has "been attempting to buy out large holdings in OECD member states."). See AL TAMINI \& COMPANY, TAXATION LAW IN THE UAE, 12-16, available at 
committed government prepared to put significant resources into the sector; $;^{413}$ and Malta and Cyprus, which possess the twin advantages of having complete sovereignty and being located within the European Union. ${ }^{414}$ In comparison with these jurisdictions, the Antilles is hampered by Dutch involvement in foreign affairs, a lack of public resources to invest in developing the sector, and a government that on a day-to-day basis is distracted by both the pending dissolution of the Antilles as a jurisdiction, and a more complex economy than some of its competitors.

Curaçao's future in the offshore financial sector largely will be shaped by developments in its relationship with the Kingdom of the Netherlands. That there will be a relationship is not in doubt, as the island has little desire for independence. ${ }^{415}$ Nonetheless, the relationship is likely to be different twenty years from now as a result of key external and internal influences. Externally, the Netherlands' obligations to, and relationship with, the European Union is likely to bring changes to the relationships among the Kingdom jurisdictions. As Professors Oostindie and Klinkers observe, the Netherlands now "is less autonomous within the European Union (which already has taken over more than one half of all legislation relevant to the Netherlands) than the Antilles and Aruba are within the Kingdom." Thus, decisions made by the European Union are increasingly likely to directly affect the Antilles.

Tensions within the Kingdom have heightened over time as well. ${ }^{417}$ As institutions whose origins lie in Dutch-Indonesian relations have proved inadequate

http:/www.tamimi.com/files/Legal\%20Brochures/taxationlaw.pdf (listing the United Arab Emirates double tax treaties and double taxation avoidance laws).

413. See Singapore Proves Itself as Attractive Jurisdiction and Business Hub, INT'L TAX REV., Sept. 2006, at 32 (Discussing Singapore's extensive network of tax treaties and favorable tax laws).

414. Malta, in COUNTRIES OF THE WORLD AND THEIR LEADERS YEARBOOK 2009, 1317-19 (2008); Cyprus, in COUNTRIES OF THE WORLD AND THEIR LEADERS YEARBOOK 2010, 580-83 (2010).

415. OOSTINDIE \& KLINKERS, supra note 6, at 221 ("Overwhelming majorities on all islands indicated no interest in a transfer of sovereignty."). Arguments against independence center on free migration to the Netherlands, the value of being part of a "prosperous and stable Kingdom," and the emergence of transatlantic communities. OOSTINDIE, supra note 21 , at 96 . The example of Suriname also provides a strong argument against independence. See id. (describing how an array of problems, including economic collapse and massive emigration, plagued post-Independence Suriname).

416. OOSTINDIE \& KLINKERS, supra note 6, at 230. Of course, the European Union is having an effect on all the dependent territories of its members, and so this trend is likely to affect other offshore jurisdictions as well.

417. Id. at 231 ("[T]he need of the Antilles and Aruba for a life line with the Netherlands has in no sense been reduced, but over time tensions between the tasks related to the Kingdom and the local autonomy have increased."). Indeed,

[d]uring the 1990s in the Antilles and Aruba [ambivalence about the Dutch role] grew as Dutch involvement and-literal-Dutch presence increased on the islands. Inescapable as the constitutional and increasingly also demographic ties with the Netherlands may be, the atmosphere of administrative consultations is invariably tense and characterized by political bickering. The Caribbean argument that "the Netherlands is impeding our autonomy" was always playing a main role. An outsider could be surprised by this state of affairs. After all, none of the dependent territories in the Caribbean has been granted the same level of autonomy as the Antilles and Aruba. However, ever since the 1990s, the fear of restricted autonomy has become a major concern for Caribbean politicians. It is one thing to secure the best deal, it is another to hold onto it. 
for the task of governing a geopolitical situation that has become quite different, ${ }^{418}$ dissension has arisen over economic aid paid by the Netherlands to the Antilles, immigration of Antilles residents to the Netherlands, ${ }^{419}$ the autonomy of the Antilles from the Netherlands, and a host of other issues. ${ }^{420}$ As a result of these mounting pressures, a renegotiation of the Kingdom relationship was undertaken in $2005 .^{42}$ Under the resulting agreement, at a date yet to be determined (originally scheduled for December 15, 2008 and since postponed), the "Netherlands Antilles will cease to exist as a political entity; Bonaire, Sint Eustatius, and Saba will become special status municipalities within the Netherlands;", ${ }^{422}$ and Curaçao and Sint Maarten will become separate countries within the Kingdom. ${ }^{423}$ The economic inequalities in the relationship between the Caribbean islands and the European territory make the formal legal equality of the Kingdom structure questionable at best. This is because of the "simple truth that the Netherlands is of eminent and even increasing importance to both Caribbean countries whereas, in reverse, this is not at all the case; not economically, not politically, and not culturally." disparity between the Netherlands, the two new Dutch countries, and the three overseas municipalities, the Netherlands has pledged financial support of more than one billion guilders. ${ }^{42.5}$ This aid, however, increases the Caribbean islands' dependence on the Dutch.

418. The Kingdom today consists of the Netherlands, with a population over sixteen and a half million, the Antilles, with a population of 227,000 , and Aruba, with a population of 103,000 . See CENTRAL INTELLIGENCE AGENCY, THE WORLD FACTBOOK available at https:/www.cia.gov/library/publications/the-world-factbook/geos/nl.html (Netherlands); url to: https:/www.cia.gov/library/publications/the-world-factbook/geos/nt.html (Netherlands Antilles); and https:/www.cia.gov/library/publications/the-world-factbook/geos/aa.html (Aruba).

419. More than 125,000 Caribbean islanders live in the Netherlands, as well. Id. at 63 .

420. For example, at a recent conference of former Prime Ministers of the Antilles, one commented in response to a question about whether the fiftieth anniversary of the Charter should be celebrated that:

We will be celebrating fifty years of being dependent on Holland. In other words, of being a colonial territory of Holland. We should not be so proud that we are part of Holland. Holland used Indonesia. It fought a war with Indonesia. It got rid of Suriname. With us, they could not get rid of us because we had the Statuut. All the money they have taken from us . . . because via us they could enter Latin America. We should not be so proud that we are part of Holland.

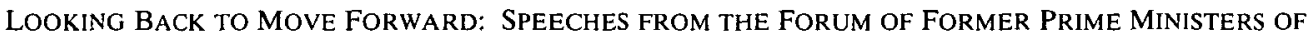
THE NETHERLANDS ANTILlES 8 (Gracita R. Arrindell ed., 2006) (quoting Juan “Juancho" Miguel Gregorio Evertsz, Prime Minister from 1973-77). Another argued that:

The Charter, Article 43, gave the government of the Kingdom the responsibility to guarantee good government in the Netherlands Antilles. So, although we had obtained our long-desired autonomy, the possibility for higher supervision was institutionalized. I guess that this gives a sense of comfort to the colonial mothers and fathers that they could slacken up on us a little but still maintain the guarantee of a grip.

Id. at 27 (quoting Maria Liberia Peters, Prime Minister from 1984-86, 1988-90, and 1990-93).

421. Press Release, Government of the Netherlands, Agreement on Division of Netherlands Antilles,

(Feb. 13, 2007) available at http://www.government.nl/News/Press_releases_and_news_items/2007/ February/Agreement_on_division_of_Netherlands_Antilles.

422. Id. This is a less autonomous status similar to that enjoyed by the French overseas territories.

423. See Government of the Netherlands, Curaçao, supra, note 6.

424. OOSTINDIE \& KLINKERS, supra note 6, at 218.

425. Dutch Make Available Over 1 Billion Guilders, DAILY HERALD (2008), available at http://www.thedailyherald.com/news/daily/j226/accor226.html. 
Looking ahead, the dual Dutch goals of addressing the Antilles' economic problems and ensuring good governance ${ }^{426}$ could be achieved by Dutch support for a major revival of the Curaçaoan offshore financial sector. This would mirror the approach of the British who have (at least until recently) encouraged offshore financial sectors in Overseas Territories like Cayman and Crown Dependencies like the Isle of Man. ${ }^{427}$ Professors Oostindie and Klinkers are skeptical of such an approach, however, arguing that the strategy successfully employed by the British is not a viable strategy for Curaçao because of the island's greater size. ${ }^{428}$ It seems unlikely that the offshore financial sector could ever become as significant a portion of Curaçao's economy as it is of the Cayman's. ${ }^{429}$ However, as noted above, passage of the New Fiscal Framework suggests that Curaçao has chosen to model its financial sector along the lines of that of Barbados, which has successfully built an offshore sector as part of a diversified economic development program. ${ }^{430}$ Importantly, Curaçao's size and economy are comparable to those of Barbados. Moreover, the fragmentation of the Antilles into separate micro-jurisdictions may partially resolve this concern, freeing Curaçao's financial sector from the need to accommodate the other islands' interests.

In sum, a revival of a successful offshore financial sector in Curaçao depends on the island both: (1) sorting out and rationalizing its relationship with the Netherlands and the other Dutch Caribbean islands; and (2) developing an ability to respond more nimbly than it has to date to customer demand and changes in onshore jurisdictions' laws and regulations. If Curaçao is to rebuild, it needs modern-day entrepreneurs, like Anton Smeets, who are able to identify opportunities and build the legal and physical infrastructure to exploit them, and a government focused on supporting such efforts. Separating Curaçao from the Antilles may be a step toward that end.

\section{B. Other Offshore Jurisdictions}

There are at least forty-four jurisdictions in the world today with populations of less than 100,000 that have at least attempted to create offshore financial sectors. ${ }^{431}$ Many of these jurisdictions are small island states having limited natural resource endowments. ${ }^{432}$ In the Caribbean alone (defined broadly), Anguilla, Antigua and

426. OOSTINDIE \& KLINKERS, supra note 6, at 151.

427. Id. at 176 .

428. Id.

429. A recently released Oxford Economics report commissioned by the Cayman Islands Financial Services Association concluded that the financial sector comprises $55 \%$ of the Cayman economy. See OXFORD ECON., ECONOMIC BENEFITS OF THE FINANCIAL SERVICES INDUSTRY IN THE CAYMAN ISLANDS 1 (2009), available at http://www.caymanfinances.com/pdf/Impact_Study.pdf.

430. See supra text accompanying note 411.

431. Nieuw Fiscaal Raamwerk 20 December 2001 P.B. 2001 nr. 146. Int'l Monetary Fund [IMF], Executive Board Integrates the Offshore Financial Center Assessment Program with the FSAP, Public Information Notice (PIN) No. 08/82, July 9, 2008, available at http://www.imf.org/external/np/sec/pn/2008/pn0882.htm ("The OFC program began in 2000. Of the fortyfour jurisdictions that were initially contacted, 42 were assessed and two jurisdictions received technical assistance in lieu of assessment. The first phase of assessment was completed in 2005.").

432. See David A. Ring, Sustainability Dynamics: Land-Base Marine Pollution and Development Priorities in the Island States of the Commonwealth Caribbean, 22 ColuM. J. ENVTL. L. 65, at 70 (1997); OOSTINDIE, supra note 21, at 113. 
Barbuda, Bermuda, the British Virgin Islands, the Cayman Islands, Dominica, Grenada, Montserrat, St. Kitts and Nevis, and the Turks and Caicos Islands all have populations of fewer than 100,000 persons. ${ }^{433}$ Among these jurisdictions, those that have achieved success with their offshore financial sectors top the list in terms of per capita gross domestic product (GDP), literacy rates, life expectancy, and most other indicators of flourishing economies. ${ }^{434}$ The alternative economic futures for these jurisdictions are quite limited: tourism, offshore financial services, and dependency on a metropolitan state for transfer payments are among the few viable options. ${ }^{435}$

Tourism undoubtedly has an important role to play in the future of many small jurisdictions, but tourism's potential is limited in several crucial ways. First, tourism as an industry is primarily a source of low-wage service-sector jobs, not the sort of economic development that provides a path to a sustainable, high-wage economy with opportunities for large numbers of citizens within the jurisdiction. Second, a substantial amount of tourism in existing Caribbean offshore jurisdictions is related to the offshore financial services sector, with businesspeople incorporating a vacation into a visit for an annual board meeting or conference. ${ }^{436}$ Without the offshore financial sector connection, such tourists might well choose to vacation elsewhere.

Third, tourism is dependent on sound economies in the onshore jurisdictions from which most tourists are drawn. An economic downturn in the United States, for example, significantly reduces income from tourism in many Caribbean destinations. ${ }^{437}$ Fourth, tourism can strain the physical environment of a jurisdiction, increasing demand for scarce fresh water, generating trash that must be disposed of, producing waste discharge from cruise ships, and so on. ${ }^{438}$ Indeed, the more successful the tourism industry, the greater the impact on the environment. While a full exploration of the potential of tourism as an economic development strategy is not our intention, we think it is safe to conclude that tourism alone is unlikely to

433. CIA, THE WORLD FACTBOOK: COUNTRY COMPARISON-GDP PER CAPITA (PPP) (July 2009), available at https:/www.cia.gov/library/publications/the-world-factbook/rankorder/2004rank.html; CIA, THE WORLD FACTBOOK-COUNTRY COMPARISON-LIFE EXPECTANCY AT BIRTH (July 2009), available at https:/www.cia.gov/library/publications/the-world-factbook/rankorder/2102rank.html.

434. CIA, THE WORLD FACTBOOK: COUNTRY COMPARISON-POPUlATION (July 2009), available at https:/www.cia.gov/library/publications/the-world-factbook/rankorder/2119rank.html.

435. Prof. Oostindie summarizes the problems small Caribbean states face in economic development well:

Many Caribbean policy-makers must have sympathized with the desperate characterization of the development process by the former Jamaican MP, the late Michael Manley, as a struggle 'Up the Down Escalator.' The limitations of scale already apparent in the 1960s have continued to haunt planners. Moreover, the ongoing restructuring of the world economy left the entire Caribbean in an ever more marginal position within an Atlantic economy itself struggling to retain some of the gravity which had seemed unbeatable decades ago.

OOSTINDIE, supra note 21, at 113 .

436. E-mail from Pilar Bush, Managing Director, AtWater Ltd., to Andrew P. Morriss, H. Ross and Helen Workman Professor of Law and Professor of Business, University of Illinois College of Law (Sept. 22, 2009 10:14 CST) (on file with author).

437. See, e.g., Caribbean Growth Dampened by Global Downturn, IMF SuRvey MAGAZINE, Dec. 10, 2008 available at http:/www.imf.org/external/pubs/ft/survey/so/2008/car121108a.htm ("Weaker foreign remittances and dampened economic activity in key sectors such as tourism would be the likely consequences of the slowdown in global economic activity.").

438. See Deborah MClaren, Rethinking Tourism and Ecotravel: The Paving of PARADISE AND WHAT YOU CAN DO TO STOP IT 9-25 (Kumarian Press 1998) (describing environmental problems caused by tourism). 
provide a sustainable economic future for more than a handful of the small states even in a location as desirable as the Caribbean. For small states with less sun and sand (e.g., the Isle of Man off the coast of Britain), or located farther from large numbers of relatively wealthy tourists (e.g., Vanuatu in the Pacific), tourism's potential is even more limited.

A second alternative is closer integration with a metropolitan country. This is the route that France has taken with many of its former colonial possessions, ${ }^{439}$ but this route, too, has its difficulties. As Aldrich and Connell conclude in their survey of French overseas territories, those territories' relationships with France, "in which grandly conceived plans for future development have not been matched by reality," are characterized by a "subtle yet thoroughly pervasive structure of dependency.", In particular, "[m]etropolitan presence and aid seem to have brought relatively high standards of living, but equally extreme dependence and vulnerability." result, the French Caribbean has been "an economic fiasco: a society which consumes but which produces practically nothing." produced high living standards through subsidies, although the benefits of those standards appear to accrue mostly to French bureaucrats seconded to the islands for government service, and the local land-owning elite rather than to the society as a whole. ${ }^{443}$

Virtually the only alternative to dependency and tourism for small states is some form of financial services sector. Although not feasible for every small state, it is the most viable path for economic development for some small jurisdictions and so will remain attractive to Curaçao and others. As we outlined earlier, we believe that there will continue to be opportunities for offshore financial sectors to introduce financial intermediation products that make sufficient economic sense to provide a viable business model. ${ }^{444}$ Of course, that many offshore jurisdictions have few economic alternatives to establishing offshore financial sectors is not a conclusive reason for onshore jurisdictions such as the United States to turn a blind eye to tax evasion occurring through those jurisdictions. Onshore jurisdictions clearly have a strong policy interest in preserving both the integrity of their domestic income tax systems and the stream of tax revenue that is critical to a mature welfare state. ${ }^{45}$ Nonetheless, in the debate over the role of offshore financial centers it is important to acknowledge the benefits that an offshore financial sector may provide to the economic development of an offshore jurisdiction.

\section{Onshore Competitors}

The benefits of offshore financial intermediation do not flow unidirectionally from onshore jurisdictions to offshore jurisdictions. Where the persistence of legal

439. ALDRICH \& CONNELL, supra note 364 , at $72-73$.

440. Id. at 163 .

441. OOSTINDIE \& KLINKERS, supra note 6, at 175.

442. ALDRICH \& CONNELL, supra note 364 , at 160.

443. Id.

444. See supra, Part III. A.1.

445. See generally Reuven Avi-Yonah, Globalization, Tax Competition, and the Fiscal Crisis of the Welfare State, 113 HARV. L. REv. 1573, 1632-38 (2000) (detailing the importance of maintaining the welfare state in the era of globalization). 
difference leads to arbitrage, both jurisdictions may benefit, just as both the United States and the Antilles benefited from the Antilles sandwich that utilized arbitrage of differences in the tax rules applicable to Antilles investors in U.S. debt versus investors in U.S. debt residing in other jurisdictions. In addition to these specific instances of mutual benefit related to particular arbitrage opportunities, a number of economists have concluded that offshore financial centers may actually stimulate onshore investment by reducing the tax costs in onshore jurisdictions of foreign investment, facilitating deferral of taxation of foreign income, or adding value to onshore goods and services. ${ }^{446}$ Moreover, offshore financial centers "provide opportunities for tax planning by multinational corporations," "enhance efficiency" and, contrary to popular assumptions, may also retard rather than accelerate undesirable global tax competition. ${ }^{447}$

In addition to benefiting onshore jurisdictions qua onshore jurisdictions, offshore financial centers also have spurred innovation in onshore financial sector activity to such an extent that existing and aspiring offshore financial centers have begun to face significant competition for the financial products and services they offer from onshore jurisdictions. In other words, offshore jurisdictions have prodded onshore jurisdictions to be more offshore-like. Onshore competition in the area of traditionally offshore activities is more significant today than it was in the past and takes two forms. First, some onshore jurisdictions seek to provide their own financial products and services (frequently copied from offshore jurisdictions) that make going to an offshore jurisdiction unnecessary. For example, in the United States, the State of Vermont has established itself as a leading jurisdiction for captive insurance companies, a business originally pioneered offshore by Bermuda and the Cayman Islands. ${ }^{448}$ Similarly, the United States competes in the worldwide banking market by offering what is essentially a ring-fenced zero tax regime for bank deposits by foreigners, competing with banks in offshore jurisdictions. ${ }^{49}$ (Elsewhere we have argued that the degree to which onshore jurisdictions like the United States and United Kingdom resemble offshore financial centers in terms of the "offshore" services they provide has been obfuscated in the past by perpetuating the offshore/onshore dichotomy. $)^{4.50}$

Second, in addition to providing competing products, onshore jurisdictions compete by exercising their own sovereignty to alter the terms of competition in their favor or in pursuit of domestic policy objectives. (We distinguish this from multilateral efforts at harmonization or creating a "level playing field" below.) The Antilles saga provides a vivid illustration of this. The United States terminated its

446. See Mihir A. Desai et al., Do Tax Havens Divert Economic Activity?, 90 ECON. LETTERS 219-20 (2006) (providing evidence that tax havens enhance activity in nearby non-havens).

447. See Dhammika Dharmapala, What Problems and Opportunities are Created by Tax Havens?, 24 OXFORD REV. OF ECON. POL'Y 661, 662 (2008) (noting that tax havens can enhance efficiency, mitigate tax competition, and enable tax planning for multinational corporations); see Desai et al., supra note 446 219,220 (noting that tax havens may retard undesirable tax competition).

448. See Morriss, supra note 242, at 60 (explaining that Vermont, in its efforts to compete with Bermuda and the Cayman Islands, has become the domestic leader In captive insurance legislation).

449. See I.R.C. $\$ 871(\mathrm{~h})$ (2009); 1983 Tax Evasion Hearings, supra note 4, at 182 (statement of Marshall J. Langer, Attorney of Counsel, Shutts \& Bowen) (noting interest has been tax free since 1921 and that U.S. taxpayers subsidize such accounts by providing free deposit insurance up to $\$ 100,000$ ); Boise, supra note 14 , at 32 .

450. See generally, Boise, supra note 14, at 24-26 (explaining the claims asserted by onshore jurisdictions that OFCs are engaging in tax competition). 
tax treaty with the Antilles and as a result there was a dramatic decline in the use of Antilles N.V.s as real estate investment vehicles and finance subsidiaries. The United States did so in part on domestic policy grounds, because it perceived the costs of continuing to sanction the Antilles sandwich as too high in terms of lost tax revenue. However, the United States also preferred to extend treaty benefits to jurisdictions that could offer more in exchange for those benefits.

The debate over the role played by offshore financial centers rarely examines onshore competitive interests. Just as we argued in the preceding subsection that the offshore jurisdictions have a legitimate interest in economic development in promoting their financial services sectors, so too it is important for the debate to recognize the legitimate interests that onshore jurisdictions have in restricting criminal enterprises, preventing tax evasion, and so forth. These interests were not asserted in the early days of offshore financial centers but first began to seriously appear in the 1980s when, as we have described, they played a role in the U.S. policy changes that ended the Curaçao boom. Of course, assertions of such interests may sometimes mask less acceptable reasons for policy changes, but it is important for all participants in the future debate over offshore financial centers' roles to recognize that there are legitimate onshore jurisdiction interests in these areas, and an accommodation that respects all parties' interests is likely to be preferable to one that does not.

This can be seen in particular in the debate over confidentiality laws. As Prof. Rose Marie Antoine has eloquently argued, the strong financial confidentiality laws in many offshore jurisdictions are a reflection of a long-standing commitment to protecting individual privacy in financial matters. ${ }^{451}$ This commitment is common to many legal systems and in some is even constitutionally mandated. ${ }^{452}$ Importantly, most financial privacy statutes of most common law offshore jurisdictions derive from, or are in fact codifications of, the 1923 decision of the British Court of Appeal in Tournier v. National Provincial \& Union Bank of England and related court decisions. ${ }^{453}$ Similarly, the availability of bearer shares in jurisdictions like Curaçao is consistent with long-standing practice in many civil law legal systems. ${ }^{454}$

Moreover, financial privacy is consistent with important social objectives, ranging from protection against criminal conspiracies to enabling people to secure their assets against kleptocratic regimes. ${ }^{455}$ In this regard, for example, Curaçao has played an important role for more than a century in sheltering both the assets and

451. See Rose-Marie Antoine, Confidentiality in OfFshore Financial Law 37 (2002) (describing how financial privacy concerns in many jurisdictions led to the development of financial confidentiality laws).

452. Id.

453. Tournier v. Nat'l Provincial and Union Bank of Eng., (1924) 1 K.B. 461 (Court of Appeal 1923) (U.K.); ANTOINE, supra note 451, at 31 ("The locus classicus on [confidentiality in finance] is the case of Tournier v. National Provincial Bank.").

454. See LANGER, supra note 9, at 101 ("Bearer shares, unknown in the United States, are common in Europe and in much of the rest of the world."); See also 1983 Tax Evasion Hearings, supra note 4, at 203-05 (statement of Marshall J. Langer, Attorney of Counsel, Shutts \& Bowen) (discussing bearer bonds and shares).

455. See Morriss, supra note 242, (arguing that regulatory competition is inevitable and therefore there are non-financial reasons for encouraging a offshore financial jurisdictions). 
the persons of Venezuelan dissidents. ${ }^{456}$ Indeed, Curaçao's traditional role as an offshore financial center for Venezuelan dissidents provides a useful frame of reference for the current debate. A Venezuelan official denounced the island in the nineteenth century as "the headquarters of the enemies of Venezuelan peace." "457 Continuing, the official said that "it had no industry other than the traffic it had made in Venezuelan blood ... Curaçao has lived on our ruin and our calamities, speculating and enriching itself." ${ }^{4.58}$ Although more colorfully phrased than the current debate, the substance of the Venezuelan complaint is little different from many of the current denunciations of offshore jurisdictions. Yet there is little question that many onshore and offshore jurisdictions share a common commitment to privacy principles generally. Outside the financial realm, for example, the European Union provides extremely strong privacy protection in a number of contexts. $^{459}$ Onshore jurisdictions need to acknowledge that offshore jurisdictions have arguments both historic and principled for maintaining financial confidentiality, and their sovereignty in determining the level of that confidentiality should be respected.

From the perspective of onshore jurisdiction law enforcement authorities and tax authorities, however, strong confidentiality laws are an impediment to the information sharing they view as critical to carrying out their missions. ${ }^{460}$ This, too, is a legitimate perspective. Tax laws in onshore jurisdictions must be enforced, and it is undeniable that tax evaders have made use of the financial confidentiality rules of offshore jurisdictions to thwart collection of taxes. Offshore jurisdictions need to, and in many instances have, found ways of accommodating legitimate onshore jurisdiction needs for information in both the law enforcement and tax spheres. This is particularly true as "there is no way to determine objectively which regulations are reasonable and which not." 461

Unfortunately, the current debate does not resemble a considered acknowledgement of the legitimate interests of all parties. For example, tax authorities in Germany, France, Britain, the United States, and elsewhere recently purchased data on private foundations established in Liechtenstein that was stolen by an employee of the Liechtensteinische Landesbank. ${ }^{462}$ The purchase and subsequent use of this data by the onshore jurisdiction tax authorities to identify tax evaders has caused a furor among offshore jurisdictions; the use illustrates both a lack of respect for basic legal principles by the onshore tax authorities and the need for Liechtenstein to consider ways to prevent the abuse of its foundation entities. ${ }^{463}$

456. See Cleland, supra note 21, at 138 (noting that "Bolivar, Paez, Miranda, Sublet, Guzman Blanco, Riero and other Venezuelan 'revolutionists' ..." spent time in Curaçao); see GosLINGA, supra note 31, at 94-106 (documenting numerous near clashes between the nations of Venezuela and Curaçao because of dissidents residing on Curaçao).

457. GOSLINGA, supra note 31 , at 91 .

458. $I d$.

459. See, e.g., Mark F. Kightlinger, Twilight of the Idols? EU Internet Privacy and the Post Enlightenment Paradigm, 14 COLUM. J. EUR. L. 1, 10-29 (2007-2008) (describing stringent European privacy laws for personal information outside finance).

460. 1983 Tax Evasion Hearings, supra note 4, at 3 (statement of William J. Anderson, Director, General Government Division, General Accounting Office) ("Tax havens are a problem for the United States primarily because their banking and commercial secrecy laws limit U.S. access to the information it needs to assure compliance with domestic tax and other laws.").

461. O'HARA \& RIBSTEIN, supra note 87, at 16.

462. Liechtenstein's Shadowy Informant, supra note 401.

463. Id.; see Tony Paterson, Fury in Liechtenstein Over German Tax Inquiry, INDEPENDENT, Feb. 20, 
Similarly, the recent behavior of UBS employees in apparently actively abetting tax fraud by American taxpayers is indicative of problems in Switzerland's approach to international cooperation. ${ }^{464}$

While the line between tax avoidance and tax evasion may be difficult to draw at times, it appears from initial accounts that, in both the Liechtenstein and UBS cases, offshore entities were well across the divide and far into tax evasion territory. At the same time, the purchase of stolen property by European tax authorities also crosses an important line, with the facilitation of the violation of Liechtenstein's laws no less a legitimate subject of concern than the violation of Germany's tax laws. As the stronger partner in any negotiations, the larger onshore jurisdiction economies need to take care to explicitly acknowledge and protect the interests of their smaller counterparts in the same way that they take care to respect the legitimate interests of other nations in other types of negotiations. ${ }^{455}$

\section{The Impact of Multilateral Institutions}

Future debates over the role of offshore financial centers will include participation by multilateral institutions to a greater extent than in the past. The success of the offshore financial services sector itself produced this reaction. The European Union's Savings Directive, the FATF's efforts to restrict opportunities for money laundering, and the IMF's efforts at increasing regulatory effectiveness among offshore financial centers are all part of broad, multilateral efforts to combat serious problems in the international financial system. But they are also all examples of one set of interests attempting to apply a set of standards that advantage their own interests to the detriment of other jurisdictions. ${ }^{466}$ The existence of mixed motives in such efforts is inevitable, as interest groups within jurisdictions seek advantages through the regulatory process. The design of the institutions engaged in such efforts can be structured to increase or decrease the special interest content of the resulting regulations, standards, and protocols.

Most importantly, multilateral institutions attempting to influence the provision of offshore financial services need to include as equals the jurisdictions engaged in providing such services and the principles and standards set through such institutions must apply with equal force to onshore and offshore jurisdictions alike. The careful exclusion of the tax exemption for interest paid on foreign-owned bank deposits

2008, available at http://www.independent.co.uk/news/world/europe/fury-in-liechtenstein-over-german-taxinquiry-784417.html; Ulrich Jaeger \& Gunther Latsch, How a Liechtenstein Bank Helped German Investigators, DER SPEIGEL, Mar. 3, 2008, available at http://www.spiegel.de/international/business/ $0,1518,539107,00 . \mathrm{html}$.

464. See Lynnley Browning, Ex-UBS Banker Pleads Guilty in Tax Evasion, N.Y. TIMES, June 20, 2008, at C1 (reporting that former Swiss banker admits helping Americans evade U.S. taxes using offshore accounts); Evan Perez \& Carrick Mollenkamp, Swiss Bank to Give Up Depositors' Names to Prosecutors, WALL ST. J. EUROPE, Feb. 19, 2009, at A1 (reporting that Swiss bank agrees to cooperate with U.S. tax authorities).

465. See generally Allison Christians, Sovereignty, Taxation and Social Contract, 18 MINN. J. INT'L L. 99 (2009) (suggesting that this regard for other jurisdictions may be implied from a "social contract" among states).

466. See Boise, supra note 14; Richard K. Gordon, The International Monetary Fund and the Regulation of Offshore Centers, in REGULATORY COMPETITION AND OFFSHORE FINANCIAL CENTERS (Andrew P. Morriss ed., forthcoming 2010). 
from the OECD's definition of harmful tax competition is a particularly egregious example of the sort of one-sided result that occurs when onshore jurisdictions write the rules by themselves or through proxy organizations. ${ }^{467}$

\section{E. The Changing Climate}

We believe it is likely that ten, twenty, and fifty years from now there will be successful offshore financial centers. The Antilles saga, however, cautions that the winners tomorrow may not be the same jurisdictions that are dominant today. This is partly because of the persistence of difference and the shifting of legal differences among various jurisdictions. But it is also because there is remarkable change in the air with respect to attitudes towards offshore financial centers. The near-collapse of global financial markets in late 2008 prompted unprecedented scrutiny into the activities of banks, insurance companies, hedge funds and other financial sector actors that caused the meltdown. ${ }^{468}$ As has frequently been the case in the past, the offshore financial centers of the world have been blamed for the failure of the financial system. ${ }^{49}$ This is so, despite clear evidence that offshore financial centers are at least as well regulated as onshore jurisdictions. ${ }^{470}$

The economic strain of the financial crisis in the United States coupled with evidence of widespread malfeasance among corporate executives in the U.S. financial services sector have led to deep concerns about the scope and effectiveness of global regulation of the financial markets. In this environment, offshore financial centers have become both easy targets of blame and the subject of pending legislation in Congress. The United States Senate currently is considering legislation called the Stop Tax Haven Abuse Act, which was proposed by Sen. Carl Levin and that has gained considerable attention because a less-comprehensive version was co-

467. Boise, supra note 14 , at 18 .

468. See President Barack Obama, Remarks by the President on 21st Century Financial Regulatory Reform (June 17, 2009) (discussing proposed reform of financial markets) (transcript available at http://www.whitehouse.gov/the_press_office/Remarks-of-the-President-on-Regulatory-Reform/).

469. Nicholas Watt, Brown Targets Switzerland in Global Tax Haven Crackdown: Tough Controls on Offshore Regimes as Avoidance Costs Taxpayers Billions, GUARDIAN, Feb. 19, 2009, at 1, available at http://www.guardian.co.uk/business/2009/feb/19/gordon-brown-tax-avoidance-switzerland (noting Gordon Brown's plan to lead other nations in a crusade against offshore financial centers was well-timed as the economic downturn provides a ready excuse to close countless tax loopholes valued at hundreds of billions annually); Robert M. Morgenthau, Op-Ed., Too Much Money Is Beyond Legal Reach, WALL ST. J., Sept. 30, 2008, at A19 "A major factor in the current financial crisis is the lack of transparency .... This opaqueness is compounded by vast sums of money that lie outside the jurisdiction of the U.S. regulators and other supervisory authorities."); M. Padmakshan, Vatican Demands Closure of Tax Havens, ECON. TIMES, Feb. 23, 2009, available at http://economictimes.indiatimes.com/News/Economy/Finance/ Vatican_demands_closure_of_tax_havens/rssarticleshow/4172245.cms (summarizing the Vatican's belief that the global financial crisis was caused by offshore financial centers with "unhealthy and inequitable financial practices" that collectively form the chief means of transferring wealth from impoverished nation to wealthy nations). Offshore financial centers also were blamed for the Asian financial crisis of 1997. See Steven Radelet \& Jeffrey Sachs, The Onset of the East Asian Financial Crisis, HARV. INST. FOR INT'L DEV., Mar. 1998, at 10, available at http://www.earthinstitute.columbia.edu/sitefiles/File/about/ director/pubs/paper27.pdf (claiming that "inflow of foreign funds was a precondition for the subsequent crisis," the bulk of which came from offshore borrowing); Injoo Sohn, East Asia's Counterweight Strategy: Asian Financial Cooperation and Evolving International Monetary Order, in G-24 DISCUSSION PAPER SERIES 2 (U.N. Conference on Trade and Dev., United Nations 2007), available at http://www.unctad.org/en/docs/gdsmdpbg2420072_en.pdf (stating that offshore financial centres were widely believed to have contributed to speculation leading to Asian crisis).

470. Andrew P. Morriss, Regulatory Intensity \& Offshore Financial Centers (forthcoming 2009). 
signed by Senator Barak Obama before he was elected President. ${ }^{471}$ Similar legislation is being considered in the House of Representatives. ${ }^{472}$ The bills represent the most sweeping attack ever on tax evasion through offshore financial centers. ${ }^{43}$

Clearly both within the United States and around the globe, offshore financial centers are being forced to accede to the demands of onshore jurisdictions in terms of cooperation and mutual legal assistance and the dramatic scaling back of the scope of financial confidentiality. It remains to be seen whether onshore and offshore governments will recognize that the offshore financial intermediation that benefits offshore financial centers also creates benefits for onshore jurisdictions. An important lesson of the Antilles saga is that for nearly two decades financial intermediation in the Antilles benefitted the United States economy by lowering the cost of capital for U.S. firms and channeling foreign investment into the U.S. real estate market. The same set of arbitrage transactions created unprecedented economic growth, dramatic expansion of the professional class and a rising standard of living for all residents. Crisis in the global financial markets should not give rise to rash legislative, regulatory, and political measures that discourage the symbiotic relationships that may develop between onshore and offshore jurisdictions.

\section{CONCLUSION}

The history of the Antilles financial sector is both colorful and instructive. Much of the Antilles early success was the product of luck and events taking place far from its shores. However, in a world of persistent legal differences, the Antilles also were among the first to identify major financial intermediation opportunities and exercise legislative agility in creating the statutory framework to exploit those opportunities. However, this process is interactive rather than static. Our theory of regime plasticity holds that as offshore jurisdictions face the challenges of change, those that continue to exercise legislative agility to adapt will thrive. Others, however, are constrained by constitutional limitations in their response to change. Like the Antilles, these jurisdictions are politically or structurally unable to recognize and appropriately react to change, and as a result may find their offshore financial sectors decimated. There is evidence in the New Fiscal Framework and other recent initiatives, that Curaçao finally recognizes the need to aggressively seek arbitrage opportunities among the differences that exist between regimes. ${ }^{474}$ Perhaps Curaçao

471. See Kevin Drawbaugh \& Corbett Daly, Obama Admin. Backs Tax Haven Bill, ReUTERS, Mar. 3, 2009, available at http:/www.reuters.com/article/politicsNews/idUSTRE52271L20090303?pageNumber= $1 \&$ virtualBrandChannel $=0 \& s p=$ true (discussing Barak Obama's endorsement of the current proposed legislation and involvement in similar prior legislation).

472. See id. ("[B]ills unveiled on Monday in the Senate and House of Representatives ....").

473. In 2001, U.S. taxpayers paid about $\$ 1.77$ trillion in taxes. By contrast, it is estimated that U.S. taxpayers utilize offshore tax havens to annually evade between $\$ 40$ billion and $\$ 70$ billion in U.S. tax liability. See Staff of S. COMm. ON Homeland SECURITY And Governmental AfFairs, 109Th Cong., Tax haven abuses: The Enablers, the Tools and Secrecy 1, 8-10 (Comm. Print 2006) ("Experts estimate that Americans now have more than $\$ 1$ trillion in assets offshore and illegally evade between $\$ 40$ and $\$ 70$ billion in U.S. taxes each year through the use of offshore tax schemes."). A comparison of these figures suggests that tax evasion through the use of offshore tax havens amounts to only about three percent of the total annual income tax collected. Although meaningful, this percentage hardly indicates that tax evasion fostered by globalization is likely to undermine the U.S. income tax system.

474. Nieuw Fiscaal Raamwerk 20 December 2001 P.B. 2001 nr. 146. 
in its re-envisioned role within the Dutch Kingdom will be sufficiently autonomous that the island can move forward once more with agility and speed to restore its once-thriving financial sector. 